INTERNATIONAL MONETARY FUND
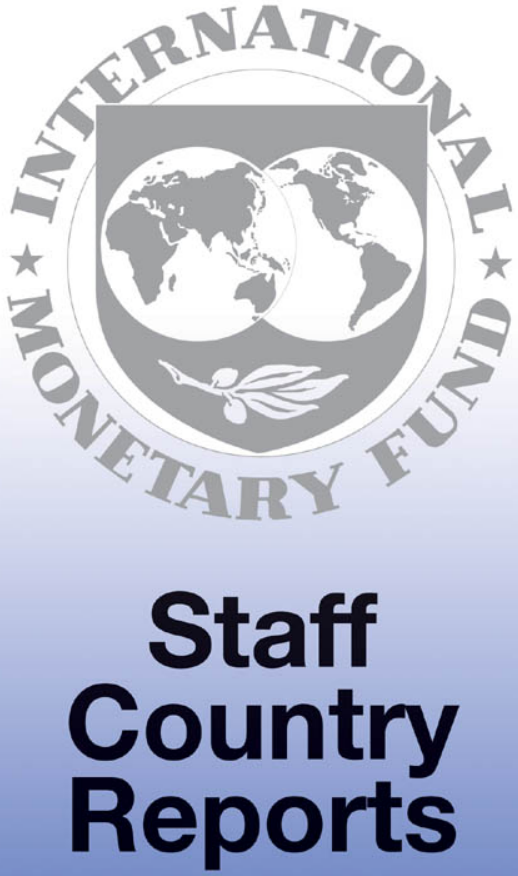


\section{Romania: 2004 Article IV Consultation and Request for Stand-By Arrangement—Staff Report; Staff Statement; Public Information Notice and Press Release on the Executive Board Discussion; and Statement by the Executive Director for Romania}

Under Article IV of the IMF's Articles of Agreement, the IMF holds bilateral discussions with members, usually every year. In the context of a combined discussion of the 2004 Article IV consultation with Romania and its request for a Stand-By Arrangement, the following documents have been released and are included in this package:

- the staff report for the combined 2004 Article IV consultation and request for a Stand-By Arrangement, prepared by a staff team of the IMF, following discussions that ended on April 26, 2004, with the officials of Romania on economic developments and policies. Based on information available at the time of these discussions, the staff report was completed on June 24, 2004. The views expressed in the staff report are those of the staff team and do not necessarily reflect the views of the Executive Board of the IMF.

- a staff statement of July 7, 20004 updating information on recent economic developments.

- $\quad$ a Public Information Notice (PIN) and Press Release, summarizing the views of the Executive Board as expressed during its July 7, 2004, discussion of the staff report on issues related to the Article IV consultation and the IMF arrangement, respectively.

- $\quad$ a statement by the Executive Director for Romania.

The documents listed below have been or will be separately released.

Letter of Intent sent to the IMF by the authorities of Romania*

Memorandum of Economic and Financial Policies by the authorities of Romania*

Selected Issues Paper and Statistical Appendix

Technical Memorandum of Understanding*

* May also be included in Staff Report

The policy of publication of staff reports and other documents allows for the deletion of market-sensitive information.

To assist the IMF in evaluating the publication policy, reader comments are invited and may be sent by e-mail to publicationpolicy@imf.org.

Copies of this report are available to the public from

International Monetary Fund • Publication Services

$70019^{\text {th }}$ Street, N.W. • Washington, D.C. 20431

Telephone: (202) 623-7430 • Telefax: (202) 623-7201

E-mail: publications@imf.org • Internet: http://www.imf.org

Price: $\$ 15.00$ a copy

International Monetary Fund

Washington, D.C. 
This page intentionally left blank 
INTERNATIONAL MONETARY FUND

ROMANIA

\section{Staff Report for 2004 Article IV Consultation and Request for Stand-By Arrangement}

Prepared by the European and the Policy Development and Review Departments

(In consultation with other departments)

Approved by Susan Schadler and John Hicklin

June 24, 2004

Contents

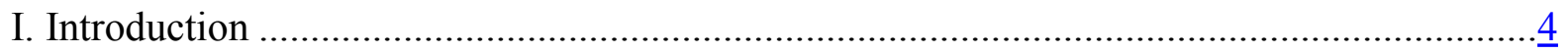

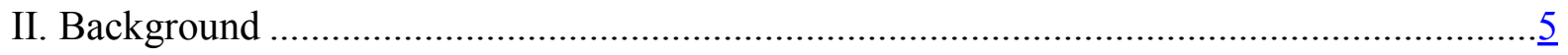

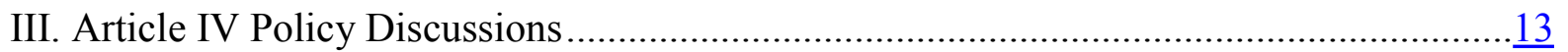

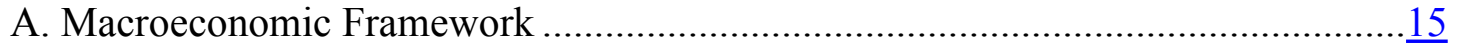

B. Fiscal Policy Over the Medium Term …….......................................................

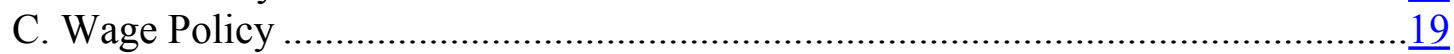

D. Monetary and Exchange Rate Policies...............................................................

E. Financial Sector Policies ..................................................................................

F. Structural Policies and the Trade Regime ………........................................

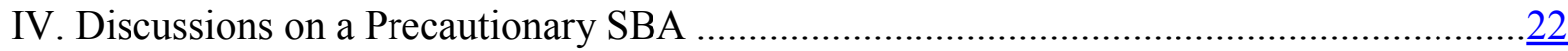

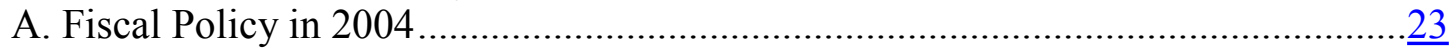

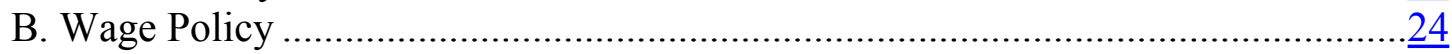

C. Energy Sector Policies, Privatization and SOE Restructuring …………………...24

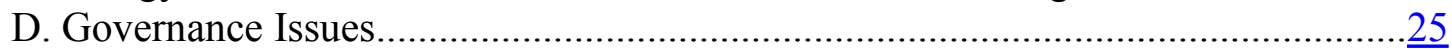

E. Monetary Policy Under the Program...............................................................

F. Vulnerabilities and Balance of Payments Prospects.............................................

V. Access, Phasing, Monitoring, and Other Issues...............................................................

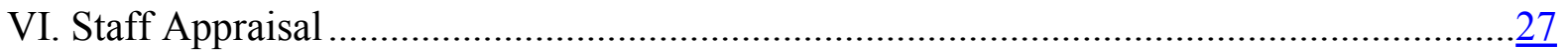




\section{Text Boxes}

Box 1. Medium-Term Current Account Developments $\underline{16}$

Box 2. Romania's Medium-Term Growth Potential.........................................................

Box 3. Romania's Pension System

Text Tables

1. Main Economic Indicators, 2000-04Q1 ……….................................................... 7

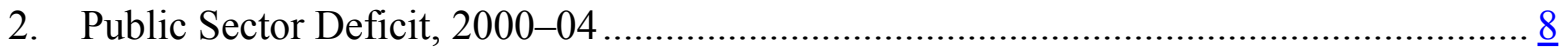

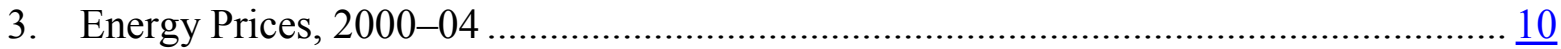

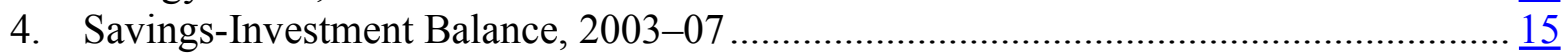

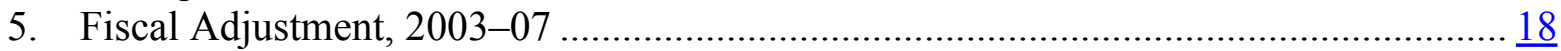

6. Pension Fund Medium-Term Projection................................................................... 19

Tables

1. Selected Economic and Financial Indicators, 1999-2004 …….................................. $\underline{30}$

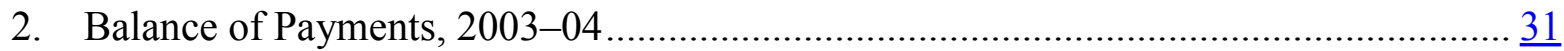

3. Summary of Consolidated General Government, 2000-04 ........................................ $\frac{32}{33}$

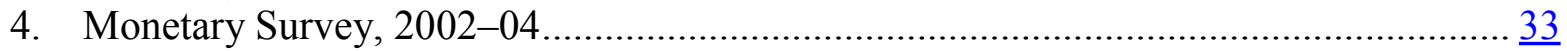

5. Implicit Subsidies and Losses in the Energy Sector .................................................... $\frac{35}{36}$

6. Medium-Term Balance of Payments Outlook, 2000-08 ……….................................. $\frac{36}{36}$

7. External Financing Requirements and Sources, 1999-2008 ……............................. $\frac{37}{38}$

8. Indicators of External Vulnerability, 1997-2004 ..................................................... $\frac{38}{39}$

9. Indicators of Fund Credit, 2000-08

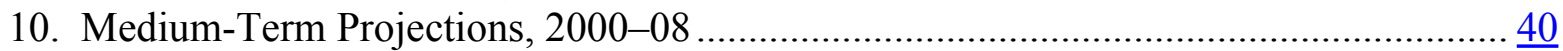

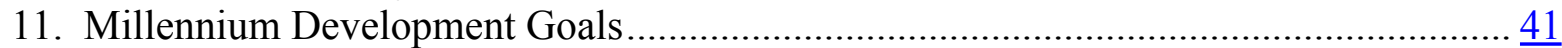

12. Public Sector Total Financing 2000-04 ............................................................

13. Schedule of Purchases Under the Stand-By Arrangement .......................................... 44

Figures

1. Selected EU Accession Countries: Comparison of Economic Indicators, 2003 .............. $\underline{6}$

2. Inflation and Exchange Rate Movements, 2001-04 ................................................

3. Industrial Production and Exports, 2000-04 …......................................................

4. Trading Partners' Import Demand and Romania's Exports, 2000-03 ............................. $\underline{8}$

5. Exports, Imports, and Trade Balance, 2000-04....................................................... $\frac{9}{9}$

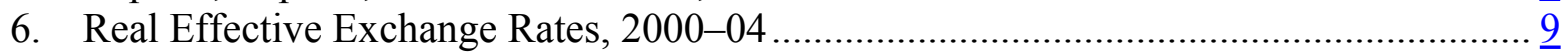

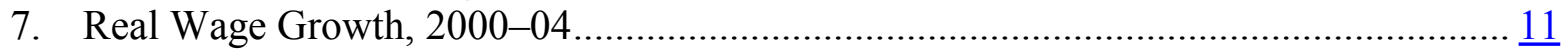

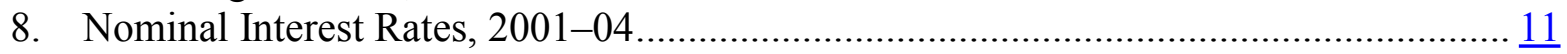

9. Reserves, Exchange Rates, and Bond Spreads, 2000-04 …….................................. $\frac{12}{14}$

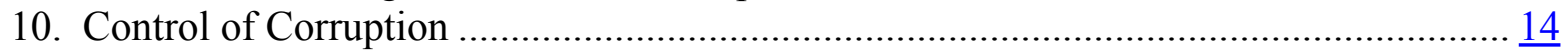

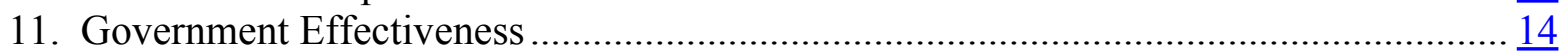

12. Current Account Deficits in Selected Transition Countries, 1998-2008 ……………... 16 
Appendices

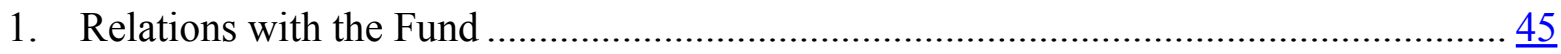

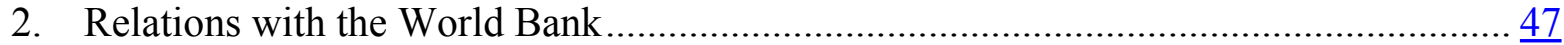

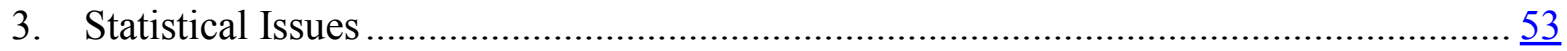

4. External Debt Sustainability Analysis ………………........................................... $\frac{56}{6}$

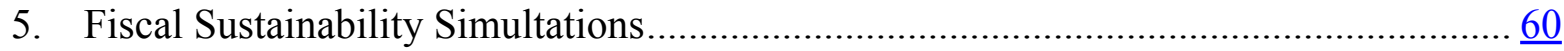

Appendix Tables

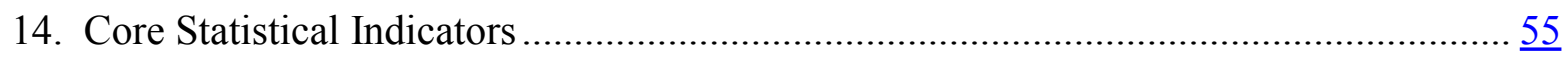

15. External Debt Sustainability Framework 1999-2009 ………………........................ $\frac{57}{58}$

16. External Sustainability Framework - Gross External Financing Need, 1999-2009 …... $\frac{58}{61}$

17. Public Sector Debt Sustainability Framework 1999-2009 ……………………............. 61

18. Public Sector Debt Sustainability Framework-Gross Public Sector

Financing Need, 1999-2009 ……………………............................................. 62

Appendix Figure

13. Debt Ratio and Gross External Financing Need, 2003-09 ……………………........... $\underline{59}$

Attachment

1. Letter of Intent and Memorandum of Economic and Financial Policies ........................ 63 


\section{INTRODUCTION}

1. Negotiations with the Romanian authorities on a program that could be supported by a Stand-By Arrangement (SBA) were held in Bucharest July 21-31, 2003, November 11-25, and February 26-March 5, 2004 and were completed in Washington April 21-26, following the Board's discussion of Romania's Ex-Post Assessment of Longer-Term Program Engagement (EPA) on April 12. The Article IV discussions were held during the February mission and the Spring Meetings in Washington. ${ }^{1}$

\section{In concluding the 2002 Article IV consultation on January 8, 2003, Executive} Directors noted that steadfast commitment to macroeconomic stabilization and accelerated structural reforms was required to sustain strong growth. They recommended perseverance with the essentially exchange-rate-based monetary policy, but noted that inflation targeting could be a sustainable medium-term framework once inflation had stabilized in single digits and wage discipline in the state-owned enterprises (SOEs) had improved. Directors emphasized that vigorously addressing the problem of SOEs' losses and quasi-fiscal activities would be crucial for completing the transition to a fully operational market economy, and for paving the way for EU accession.

\section{Romania made progress in addressing the issues raised by Directors in the} context of the last SBA. In 2001-03, fiscal and monetary polices succeeded in attaining the disinflation target. Privatization accelerated, employment in SOEs was reduced substantially, and utilities' collection rates improved. However, rapid credit growth and an excessive minimum wage increase in 2003 led to a widening of the external current account deficit and prevented faster disinflation. The business climate improved owing to greater macroeconomic stability, strengthened transparency of the tax system, and progress toward EU accession, but remained adversely affected by governance issues.

\section{The Executive Board discussed Romania's Ex-Post Assessment of Longer-Term} Program Engagement on April 12, 2004. Executive Directors concluded that a strong precautionary SBA with low access would help to strengthen the momentum for structural reforms, and support the authorities' efforts toward EU accession. They stressed the importance of strong ownership and front-loaded conditionality, supported by prior actions in critical reform areas. Moreover, Directors emphasized that macroeconomic stabilization

\footnotetext{
${ }^{1}$ The missions, led by Mr. Mates, included Messrs. Westphal, Gueorguiev, and Tieman (all EUR), Lall (PDR), and the resident representative, Mr. Justice. Ms. Schadler, EUR Deputy Director, participated in the Article IV discussions. The mission met with Prime Minister Năstase, Governor of the National Bank of Romania (NBR) Isarescu, Minister of Public Finance Tanasescu, Minister of Economy Popescu, President of the Privatization Agency Musetescu, Minister for European Integration Puskas, the President of the Pension House Giurescu, the President of the Forecasting Commission Panaite, commercial bankers, the Council of Foreign Investors, and the Romanian Businessmen's Association. Mr. Croitoru, Advisor to the Executive Director for Romania, participated in many of the meetings.
} 
hinged critically on completing structural reforms, including in the areas of privatization and governance.

\section{The authorities have requested a new precautionary 24-month SBA, to secure} macroeconomic stabilization and keep EU accession on track. They are aware that macroeconomic stability could be at risk if policies yield to populist pressures in the run-up to parliamentary and presidential elections in November 2004. Moreover, EU accession in 2007 requires persistent pursuit of structural reforms. In the authorities' view, both challenges can be best addressed in the context of a Fund arrangement, which would also facilitate coordination with other international financial institutions. Political support for EU accession remains strong across the political spectrum, reducing the risk of program slippages. The Romanian government has so far concluded 24 chapters of the acquis, and expects to conclude two more chapters by end-June.

6. The World Bank expects to disburse the second tranche of the PSAL II by mid2004, and has started negotiations on a three-year Programmatic Adjustment Loan (PAL). The PAL focuses on civil service and judicial reform, public services, and the business environment. Reflecting discussions with Fund staff, the Bank has strengthened privatization and energy sector conditionality (Appendix II). The Fund and Bank are cooperating closely on the issues of arrears, energy sector reforms, railway and mining sector restructuring, governance, and the business environment.

\section{Romania accepted the obligations of Article VIII, Sections 2, 3 and 4 of the} Articles of Agreement in March 1998. The exchange system is free of restrictions on payments and transfers for current international transactions. Owing to financial constraints during the ongoing transition, Romania has not indicated its willingness to participate in the HIPC Initiative. The statistical base is broadly adequate for surveillance and program monitoring (Appendix III).

\section{BACKGROUND}

8. After uneven performance in the 1990s, macroeconomic policies improved in 2001-03. The legacy of Ceausescu and stop-and-go policies during the early transition left Romania behind other transition economies (Figure 1). However, under the most recent SBA, macroeconomic imbalances were reduced through tight fiscal policy, strong measures to improve the financial performance of SOEs, and accelerated privatization. The NBR slowed depreciation and achieved substantial disinflation, lowering the annual inflation rate from 40 percent in early 2001 to 12\% percent in April 2004 (Figure 2). Macroeconomic stabilization, which preserved the competitiveness achieved with the 1999 depreciation, and improved prospects for EU accession created a positive supply response, strengthening industrial production and exports (Text Table 1, Figure 3). Despite these successes, Romania still lags recent accession countries with respect to price stabilization, the private sector share in the economy, the quality of governance, and FDI. Even though the Agency for Privatization has recently accelerated the sale of its portfolio, privatization projects in the 
energy sector - key to ensuring new investment and efficiency in the sector- have been delayed.

Figure 1. Romania: Selected EU Accession Countries: Comparison of Economic Indicators, 2003
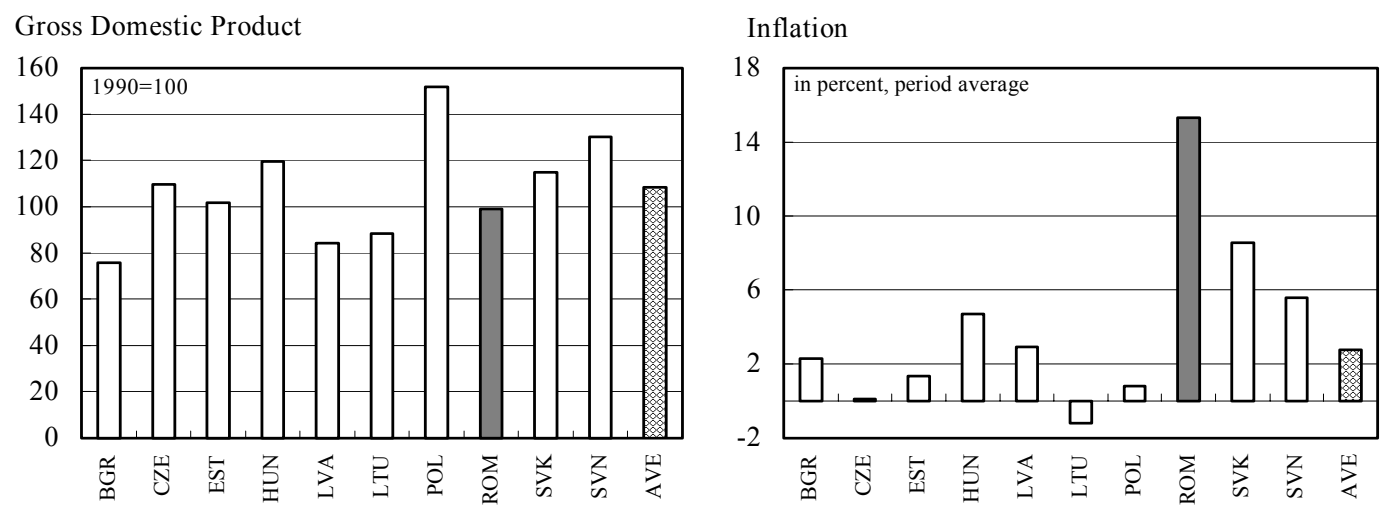

Transition Score 1/

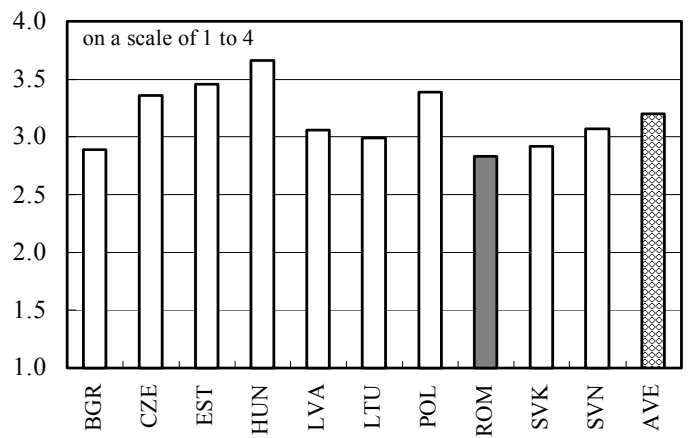

Cumulative FDI Per Capita, 1996-03

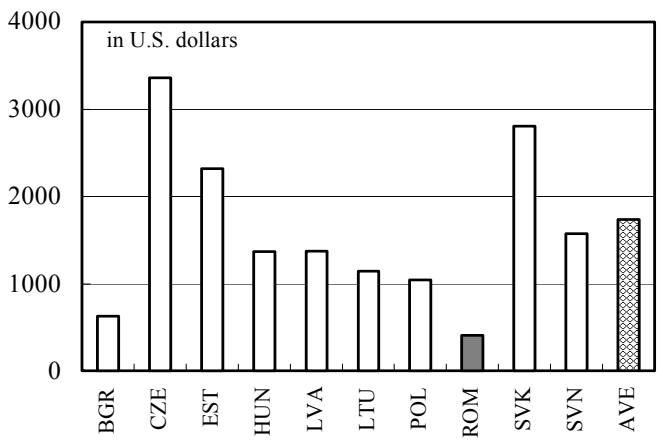

Total Public Debt

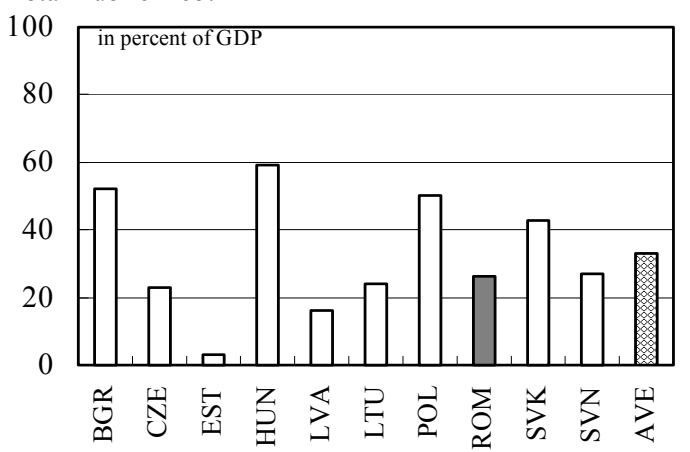

\section{External Debt}

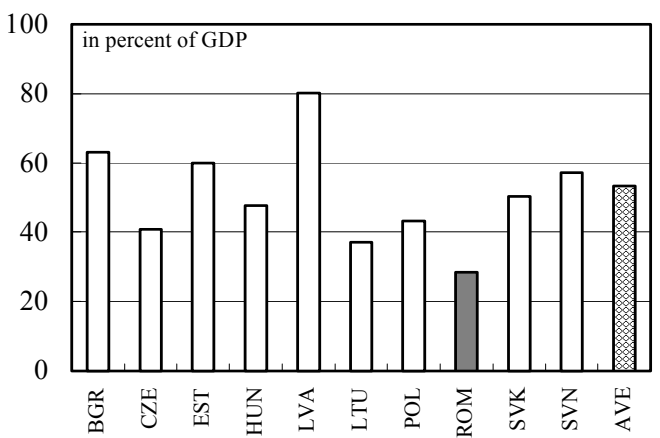

Sources: World Economic Outlook, Global Development Finance 2002, World Bank and Transition Report 2003, European Bank for Reconstruction and Development.

1/ EBRD transition score, averaged across enterprise, markets, infrastructure and financial institutions. 
Table 1. Romania: Main Economic Indicators, 2000-2004Q1

\begin{tabular}{lccccc}
\hline & 2000 & 2001 & 2002 & 2003 & $2004 \mathrm{Q} 11 /$ \\
\hline & (year-on-year real growth unless indicated otherwise) \\
GDP & 2.1 & 5.7 & 5.0 & 4.9 & 6.1 \\
Final domestic demand & 2.1 & 6.9 & 3.5 & 7.3 & 7.9 \\
Total consumption & 1.5 & 6.3 & 2.4 & 6.9 & 8.1 \\
Gross fixed capital formation & 5.5 & 10.1 & 8.2 & 9.2 & 7.3 \\
Net exports (contribution) & -2.3 & -3.1 & 0.9 & -2.8 & -1.1 \\
Exports of goods and services & 23.4 & 12.1 & 17.6 & 11.1 & 10.2 \\
Imports of goods and services & 27.1 & 18.4 & 12.0 & 16.3 & 12.4 \\
Current account & -3.9 & -5.5 & -3.4 & -5.9 & -0.5 \\
(percent of annual GDP) & & & & 14.1 & 11.8 \\
12-month inflation (eop) & 40.7 & 30.3 & 17.8 & 6975 \\
Official reserves (eop, US\$ million) & 3466 & 5090 & 6975 & 7994 & 8303 \\
\hline
\end{tabular}

Sources: National Institute for Statistics; Ministry for Economic Development and Forecasting; and Fund staff projections.

$1 /$ Preliminary data and staff estimates.

Figure 2. Romania: Inflation and Exchange Rate Movements, 2001-04

12 month percent change

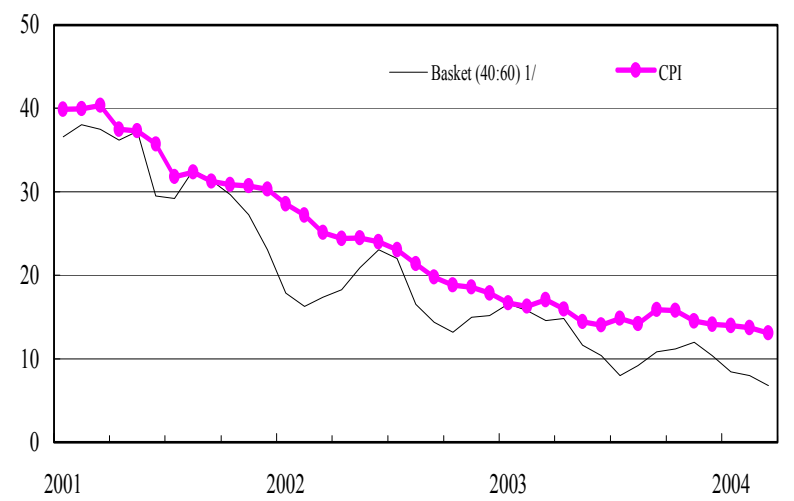

Source: Romanian authorities and Fund staff estimates.

1/ Basket consists of 40 percent of U.S. dollar and 60 percent euro, which approximates nominal effective exchange rate for lei.
Figure 3. Romania: Industrial Production and Exports, 2000-04 1/

$(1999=100)$

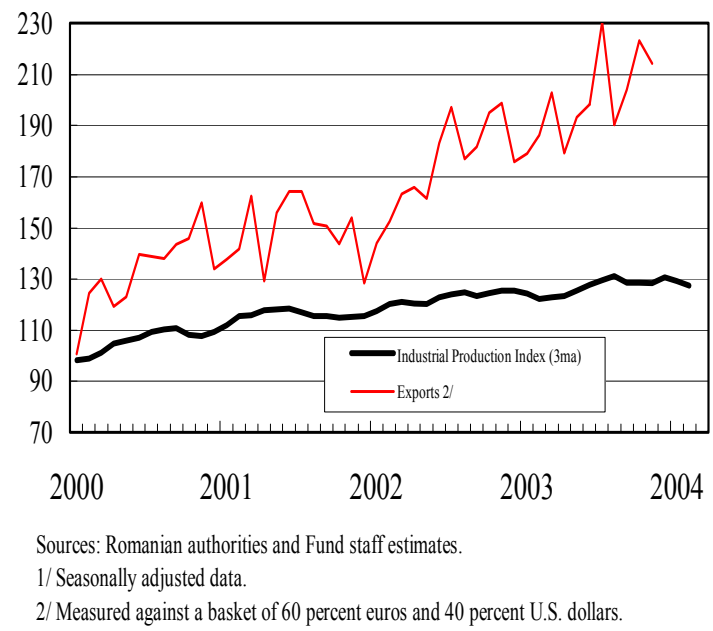


9. In 2003, domestic demand picked up and the current account deficit widened, notwithstanding continued strong competitiveness and export growth:

- $\quad$ Reflecting confidence of banks and households, a sharp increase in credit to the private sector contributed $2 \frac{1}{2}$ percentage points to the growth of domestic demand, which grew by $7 \frac{1}{4}$ percent, compared to $3 \frac{1}{2}$ percent in 2002 ; a large minimum wage increase and the ensuing strong economy-wide wage growth contributed another 0.6 percentage point to higher domestic demand growth. Delays in adjusting energy prices to higher import costs in early 2003, which increased the losses in the sector by 0.4 percent of GDP, also adversely affected the current account deficit. As a result, final domestic demand grew much faster than output and the current account deficit widened to almost 6 percent of GDP, increasing macroeconomic risks.

- $\quad$ Romania has preserved competitiveness, despite the slowdown in depreciation and recently strong domestic demand. Exports remained the strongest component of aggregate demand and Romania continued to increase market share in its main trading partners (Figures 4 and 5). The real effective exchange rate (REER) in CPI terms appreciated only modestly in 2002-03. The ULC-based REER

Figure 4. Trading Partners' Import Demand and Romania's Exports, 2000-03

(Percent change from four quarters earlier)

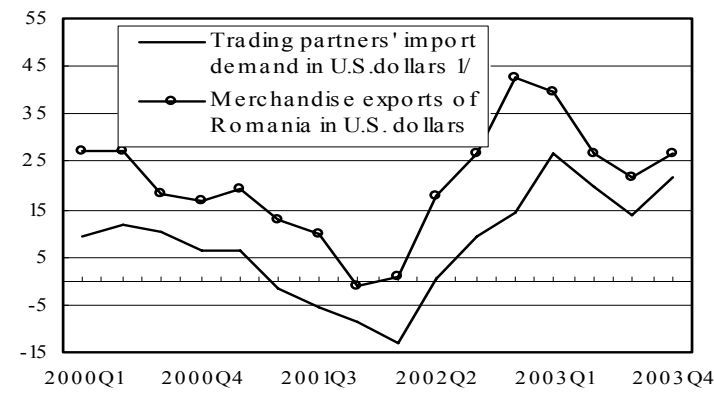

Sources: Romanian authorities, Direction of Trade Statistics (DOTS) and Fund staff estimates.

1/ Trade-weighted average for Romania's all trading partners. even depreciated, with strong productivity gains and cuts in payroll taxes offsetting wage increases (Figure 6).

\section{Public sector policies provided mixed support for stabilization:}

Budgetary developments were helpful as the general government deficit was reduced, primarily through savings on interest payments, but also with expenditure reduction in 2001-02, far-reaching tax reforms in 2002, and Table 2. Romania: Public Sector Deficit, 2000-04 (In percent of GDP) improved collections in 2003 (Text Table 2). In 2003, the authorities overperformed, for the third year in a row, by reducing the deficit to 2.3 percent of GDP, relative to the target of 2.7 percent of GDP. Progress in reforming tax administration and the effects of the new VAT

\begin{tabular}{lrrrrr}
\hline & 2000 & 2001 & 2002 & 2003 & $20041 /$ \\
\hline General Consolidated Government 2/ & & & & & \\
$\quad$ Revenues & 31.2 & 30.1 & 29.7 & 30.0 & 29.8 \\
$\quad$ of which: tax revenue (excl. contributions) & 18.5 & 17.3 & 16.9 & 18.3 & 18.9 \\
$\quad$ contributions & 10.8 & 10.7 & 10.7 & 9.8 & 9.4 \\
$\quad$ Expenditures & 35.3 & 33.3 & 32.3 & 32.3 & 31.9 \\
Overall balance & -4.0 & -3.2 & -2.6 & $-2.34 /$ & -2.1 \\
State-Owned Enterprise Sector & & & & & \\
SOE financing requirement & 3.1 & 3.3 & 2.9 & 2.8 & 1.5 \\
Implicit Subsidies Gas Sector 3/ & 3.6 & 3.4 & 1.9 & 2.2 & 1.4 \\
\hline
\end{tabular}

1/ Staff estimates.

2/ Figures include the revenue and expenditure of the National Road Administration from 2002 onwards. 3 / Reflects the difference between the domestic gas producer price and the price of imports, as well as the loss on collection.

4/ Financing data suggest a lower deficit and are still in proces of reconciliation. 
Figure 5. Romania: Exports, Imports and Trade Balance, $2000-04$
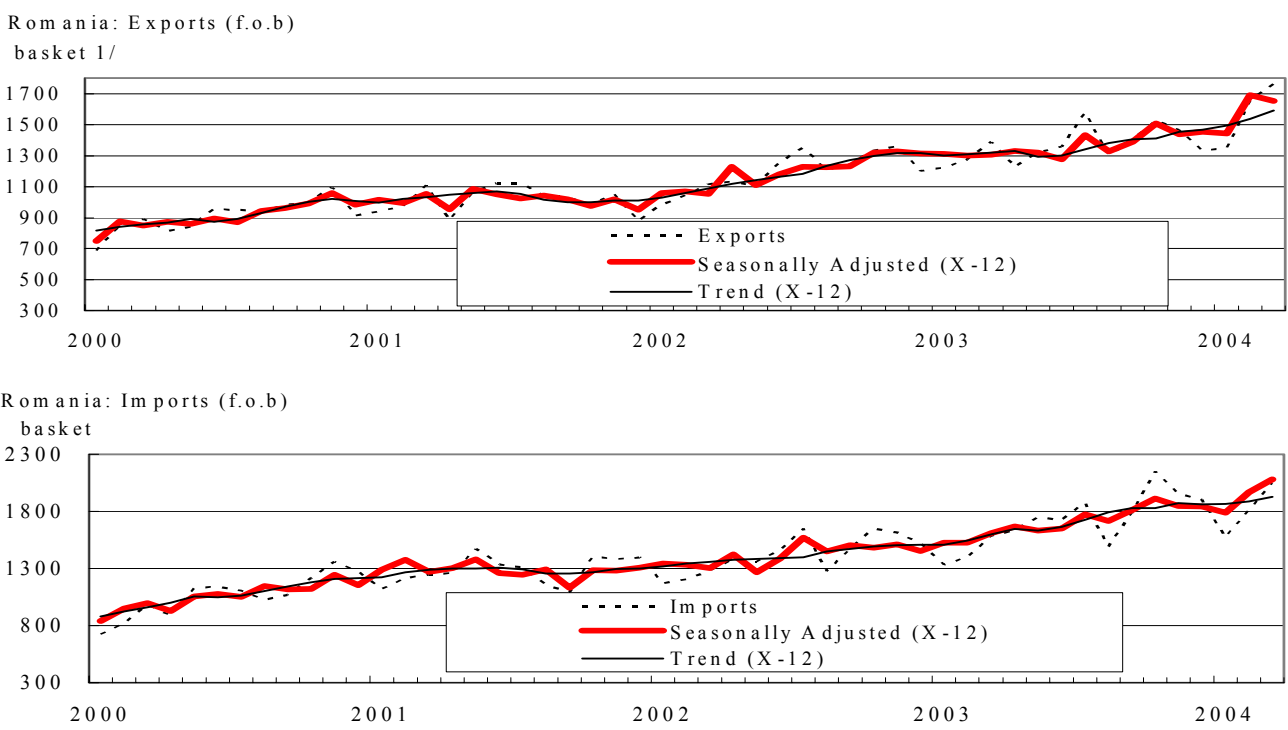

Rom ania: Trade Balance (f.o.b)

basket

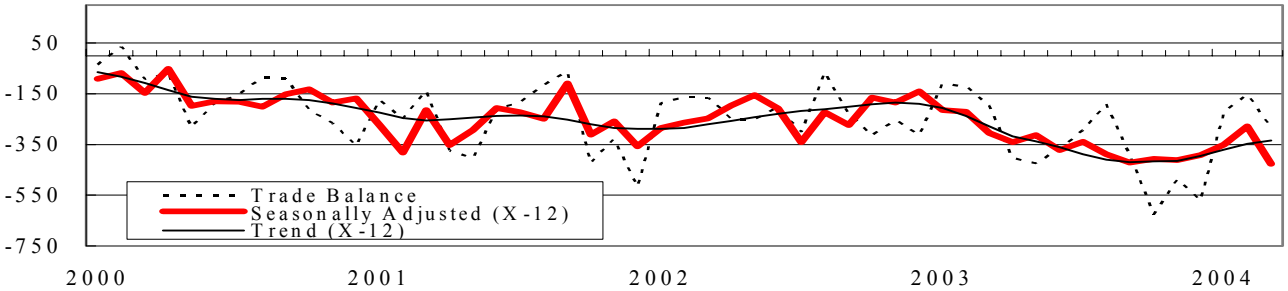

Source: Romanian authorities and Fund staff estimates.

$1 /$ Basket consists of 40 percent of U.S. dollar and 60 percenteuro, which approximates nom inal effective exchange rate for lei.

Figure 6. Romania: Real Effective Exchange Rates, 2000-04 (3-Month Moving Average; 1998=100)

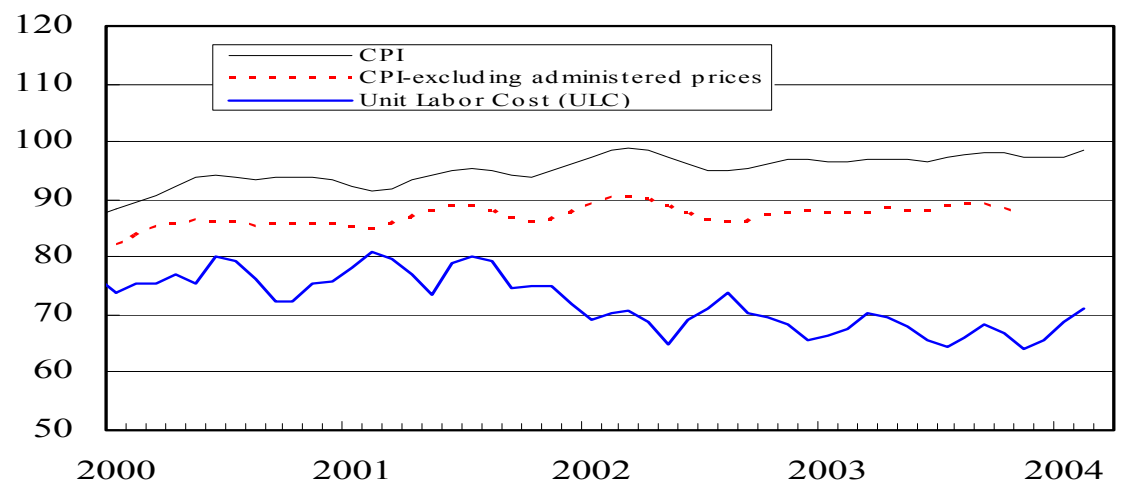

Sources: Romanian authorities, and Fund staff estimates. CPI based measures use INS weights, while ULC-based REER includes advanced economy partners only. 
and profit tax laws, which broadened the tax base and eliminated distortionary preferences, increased tax collections (excluding social security contributions) by an impressive 17 percent in real terms in $2003 .^{2}$ Following a 3 percentage point cut in 2002 , the authorities further cut the social security tax rates by 5 percentage points in 2003 , and another 3 percentage points in 2004, while collections recently improved. On the expenditure side, the social safety net was strengthened to alleviate the impact of energy sector reforms.

- $\quad$ Fiscal developments outside of the general government were on balance also helpful. After a delayed policy response to import prices in early 2003, gas prices were increased substantially in the second half of 2003 and early 2004 (Text Table 3). Electricity prices were brought to the cost recovery in September 2003, but further increases will be needed to provide an appropriate return on equity. Consumer heating prices were also raised toward cost recovery levels. Collections in the gas and electricity sectors are now high, but district heating collections remain weak, although they improved in Q1 2004.

Table 3. Romania: Energy Prices, 2000-04 1/

(In U.S. dollars, excl. VAT)

\begin{tabular}{lccccr}
\hline & 2000 & 2001 & 2002 & 2003 & March 2004 \\
\hline Electricity & 37 & 38 & 47 & 54 & 71 \\
Natural Gas & & & & & \\
$\quad$ Households & 49 & 60 & 83 & 100 & 129 \\
Other users & 49 & 74 & 80 & 93 & 115 \\
Producer wellhead prices & $\ldots$ & $\ldots$ & $\ldots$ & 29 & 52 \\
& 11 & 12 & 18 & 20 & 21 \\
District Heating 2/ & & & & & \\
& & &
\end{tabular}

1/ Units of measurement: Electricity, USD/MWh; Gas, USD/1000m3; District Heating, USD/Gcal.

2/ National Reference Price.

${ }^{2}$ Scope for further improvement remains: according to the MoF's database, the net increase in tax arrears (excluding interest and penalties) of the largest 549 debtors was equivalent to 0.6 percent of GDP in 2003, with two private oil refineries responsible for a large share of the increase. 
- Wage discipline, often a weak point in the past, remained mixed in 2003 (Figure 7). Following low wage growth in 2002, net economy-wide real wages grew by about $83 / 4$ percent in 2003, pushed by the large minimum wage increase. ${ }^{3}$ Strong wage growth continued in Q1 2004. On the positive side, owing to a cut in the payroll taxes, labor costs increased by $53 / 4$ percent in real terms in 2003, broadly in line with productivity. The ceiling on SOE wage bills was more successful in reducing employment than wages: while wages in 76 large monitored SOEs moved in line with economy-wide wages in

Figure 7. Romania: Real Wage Growth, 2000-04 (percent change over 12-months earlier 3-month moving average)

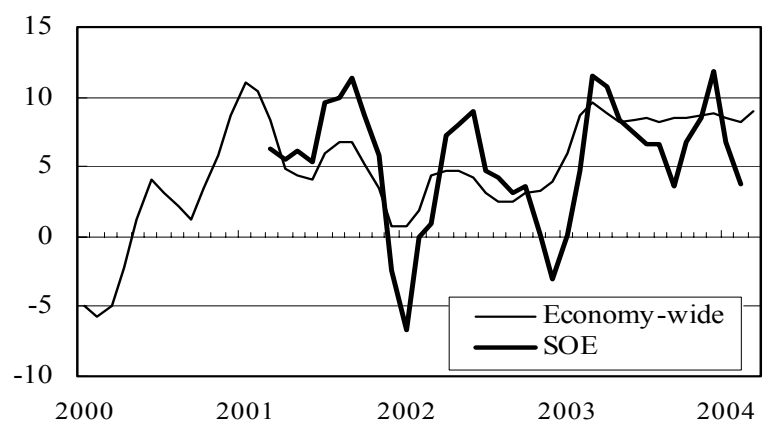

Sources: Romanian Authorities; and Fund staff estimates. 2003, employment was reduced by 8.4 percent by attrition and layoffs.

\section{An exchange-rate-based monetary policy has been successful in accomplishing disinflation but has faced challenges in containing credit growth; systemic financial risks are low but growing:}

- $\quad$ Since early 2001, the NBR has used the exchange rate as an implicit nominal anchor. The NBR has gradually reduced the depreciation rate, in line with its announced inflation target, while allowing substantial short-term variability of the exchange rate. Moreover, restrictions on short-term capital inflows have given the NBR a degree of autonomy in setting the policy interest rate, which it has used to support disinflation by keeping lei interest rates positive in real terms. Nominal

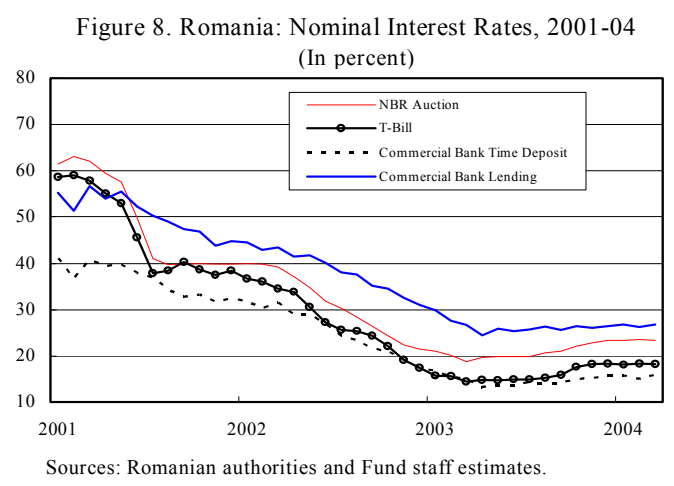
interest rates declined until mid-2003, but in the second half of the year the NBR reversed the trend in response to some weakening in the balance of payments, rapid credit growth, and the slowdown in disinflation (Figures 8 and 9).

\footnotetext{
${ }^{3}$ High wage growth particularly hurt railways, where the minimum wage adjustment pushed the entire wage scale up almost proportionally, and the mining sector, substantially increasing the losses and arrears in these two sectors.
} 
Figure 9. Romania: Reserves, Exchange Rates, and Bond Spreads, 2000-04

\section{Reserves}

Millions of U.S. dollars, with fixed cross rates

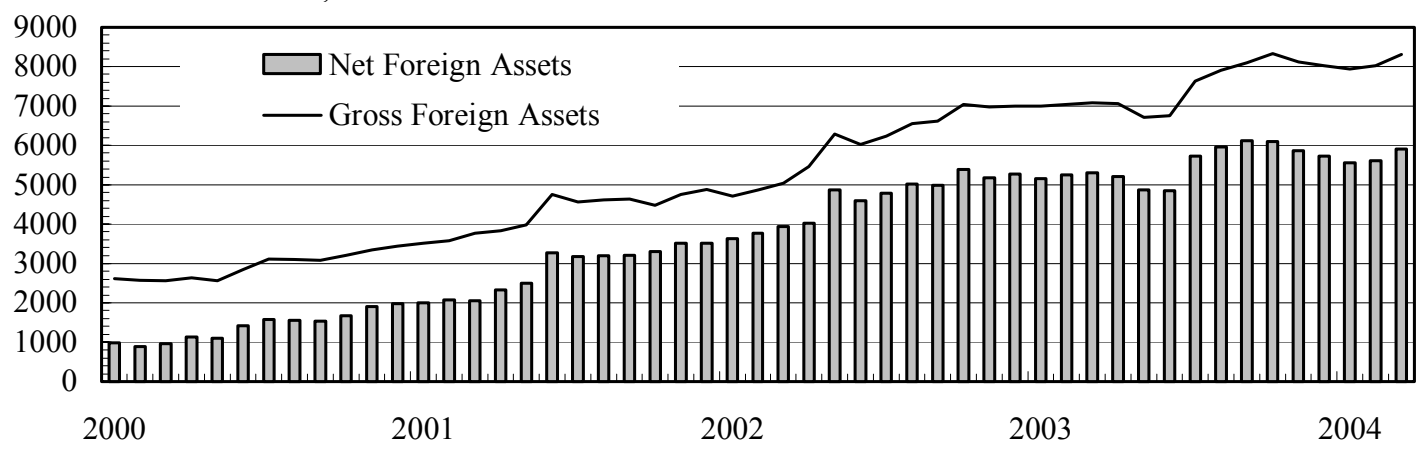

Monthly Depreciation Rate of Lei

Three-month Moving Average

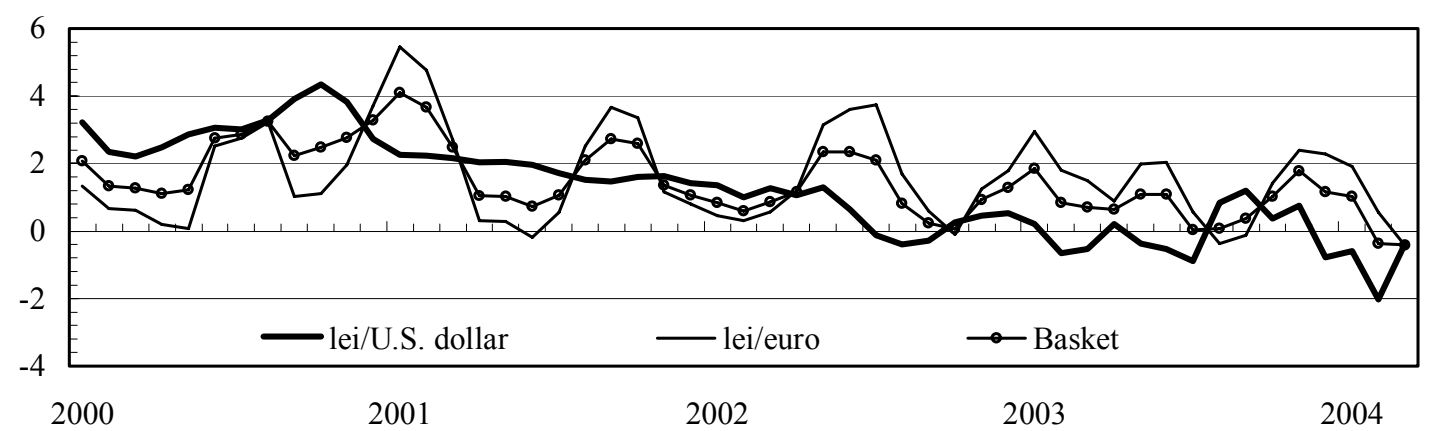

Bond Spreads Against Comparable-Maturity German Bonds

\section{Basis points}

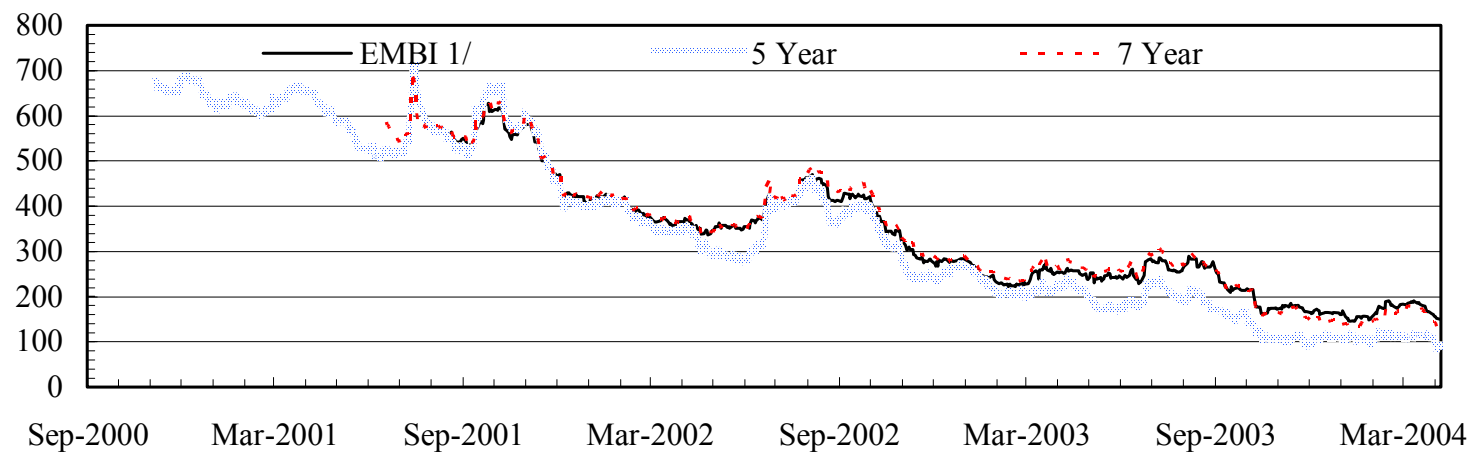

Sources: Romanian authorities; Fund staff calculations and Bloomberg.

1/ J.P Morgan Global EMBI+, excluding Latin American Bonds. 
- The improved confidence of banks and households and lower perception of country risk led to very rapid credit growth of about 55 percent in real terms in 2003. Consumer and mortgage credit tripled in real terms, albeit from a low base, while corporate credit also remained strong.

- According to the 2003 FSAP assessment, systemic risks for the financial system, while growing, are still low. Banks are well capitalized and liquid, and financial soundness indicators and stress tests suggest that banks can withstand various shocks. Loans classified as "doubtful" and "loss" have stabilized at about 4 percent of total loans. Banks have insured about half of their household loans with domestic insurance companies, which in turn have reinsured some of this exposure abroad. However, owing to strong credit growth, banks are rapidly increasing exposure to credit and market risks.

\section{Progress in structural reforms was mixed, and governance remains a problem:}

- Years of slow privatization still hold back the economy. However, progress is now evident. As indicated by the most recent data, the private sector accounted for only 65 percent of GDP in 2002, the smallest share among new member states of the EU and accession candidates. Recently, the authorities stepped up their efforts and implemented a large-scale employment reduction program to facilitate privatization. Overall, 35 large companies with over 112,000 employees were privatized in 2001-03, of which half in the last year. Although energy sector privatization has been slow, a number of projects are now in the pipeline, the most important of which is the privatization of the largest company in the country, the oil and gas producer Petrom. However, short deadlines for some privatization projects, including those in which minority private shareholders benefited from the write-off of tax arrears, have raised transparency concerns.

- In addressing governance and corruption problems, Romania stills lags other countries in the region. Based on the World Bank governance database (Figures 10 and 11), Romania lags particularly with respect to government effectiveness and the control of corruption. And while the indicator on effectiveness improved between 1996 and 2002, the indicator on corruption worsened.

\section{ARTicle IV Policy Discussions}

13. The Article IV discussions focused on external current account risks, rapid credit growth, and the medium-term fiscal stance; on the structural side, governance issues and the need to accelerate privatization played a prominent role. Growth in the past few years benefited from progress with stabilization and a favorable competitive position. However, to sustain this performance, further efforts are needed to reduce inflation to low single digits and to keep the current account deficit within a safe range. The main risks for these 
objectives are large wage increases, rapid credit growth and fiscal pressures, which could lead to overheating and an unsustainable real effective appreciation of the leu. Moreover, maintaining strong growth performance requires an improvement in the business climate and a decisive break with the past in terms of governance.

Figure 10. Romania: Control of Corruption

Regional comparision, 1996 and 2002, on a 0 to 100 scale $1 /$

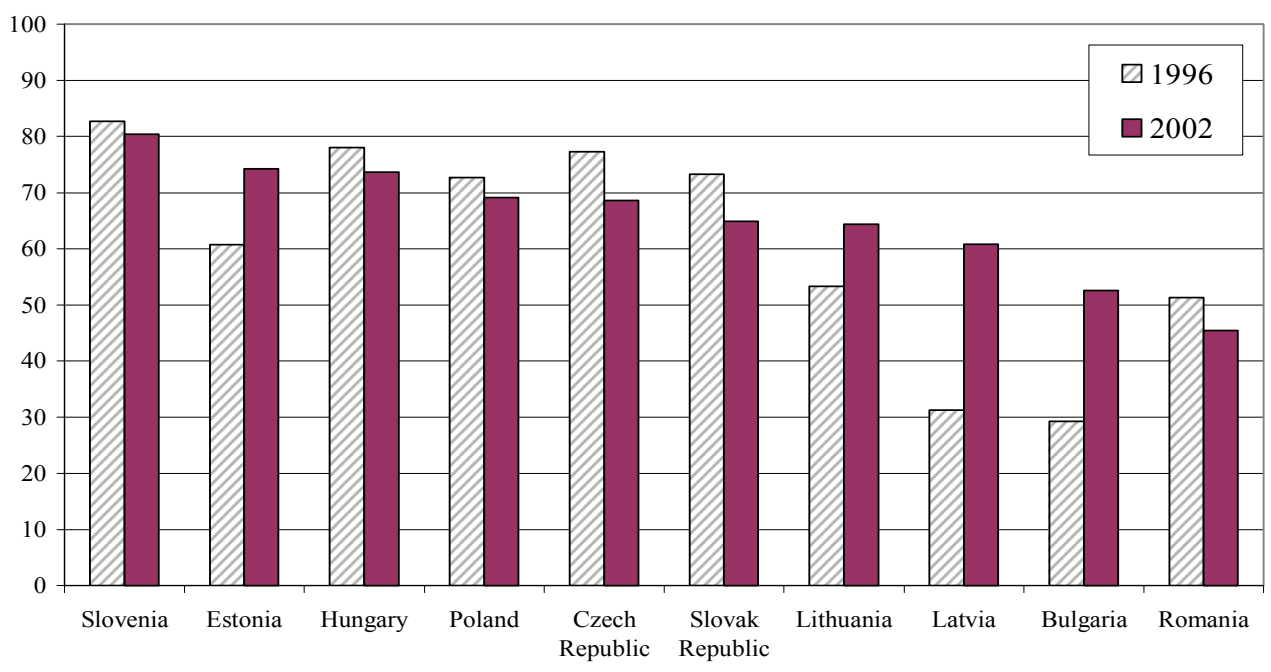

Source: D. Kaufmann, A. Kraay, and M. Mastruzzi, 2003, Governance Matters III: Governance Indicators for 1996-2002, World Bank. 1/ A higher number signifies better control of corruption, i.e., less.

Figure 11. Romania: Government Effectiveness Regional comparision, 1996 and 2002, on a 0 to 100 scale 1/

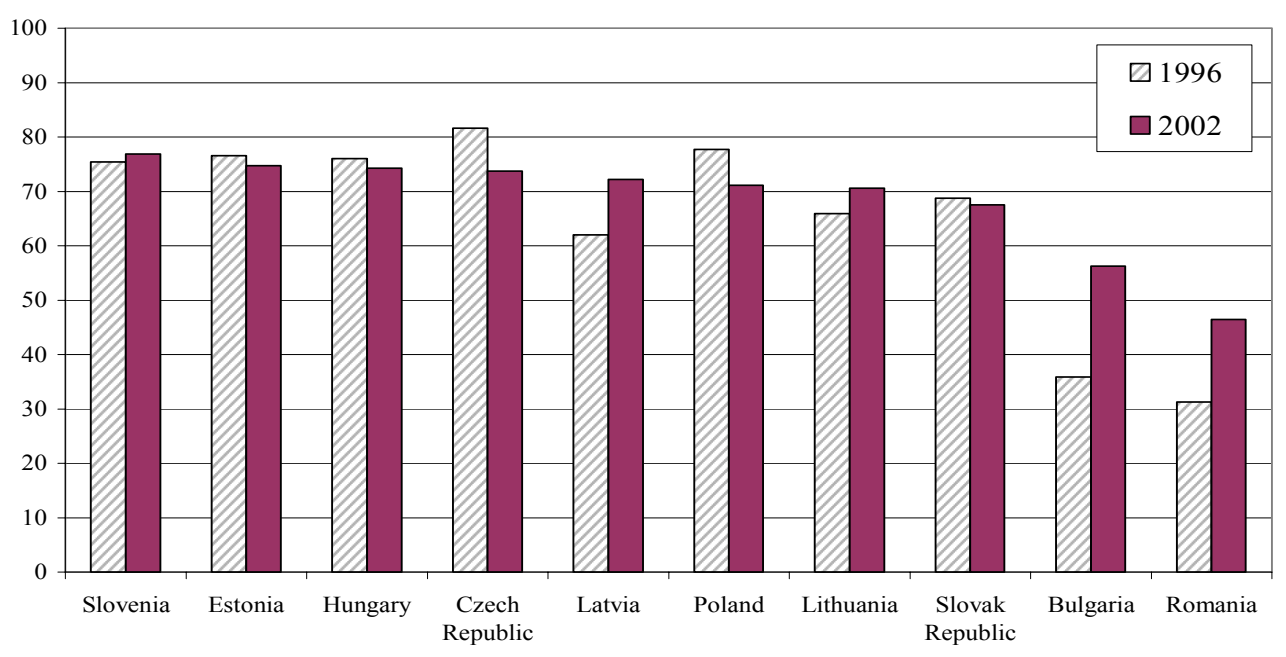

Source: D. Kaufmann, A. Kraay, and M. Mastruzzi, 2003, Governance Matters III: Governance Indicators for 1996-2002, World Bank 1/ A higher number signifies a more effective government. 


\section{A. Macroeconomic Framework}

\section{Staff viewed continuing macroeconomic stabilization and tight fiscal policy as} crucial for sustaining strong growth. Staff pointed out that the exchange rate-based stabilization, even in Romania's soft variant, had inherent risks and could be sustained only if competitiveness were preserved and the current account deficit kept well within safe margins, with fiscal policy playing a central role in this process. In particular, as neither low inflation nor monetary policy credibility had yet been established, while wage policies had often slipped, fiscal policy needed to be more supportive. Moreover, the experience of other transition economies demonstrated the importance of reducing the budget deficits during periods of high growth to prevent a deterioration to unsustainable levels during recessions. Staff therefore argued for a general government deficit target of less than 2 percent of GDP over the medium term, supported by measures to contain credit growth, to facilitate a current account deficit of about 5\%/4 percent of GDP (Box 1). Regarding potential GDP growth rate, staff saw 5 percent as achievable, provided the reform effort was strong, although downside risks dominated (Box 2). The target to reduce inflation gradually to 4 percent by 2008 was seen as appropriate, given the need for further relative price adjustments.

\section{The authorities were more sanguine than staff about medium-term risks.}

Pointing to trends in other transition economies, they saw the sustainable level of the current account deficit in a range of 5 $\frac{1}{2}-5 \frac{3}{4}$ percent of GDP, which would be consistent with a general government deficit of $2 \frac{1}{2}-3$ percent of GDP over the medium term. The authorities justified the budget relaxation by the need to catch up with neighboring countries in infrastructure and accommodate the costs of EU accession. They also indicated their intention to expand investment in infrastructure via public-private partnerships (PPPs). The expansionary budgetary stance was expected to be offset by improvement in SOEs' financial performance, which would keep the current account deficit at a prudent level. Staff, however, pointed out that the authorities' fiscal target would lead to a widening in the external current account deficit to about $6 \frac{1}{2}$ percent of GDP, which could threaten Romania's external position (Text Table 4). Both sides agreed on the need for further structural reforms, particularly on financial and payment discipline, privatization, and governance, to prepare the economy for EU accession. However, the authorities pointed to the tension between the socially acceptable and the economically desirable speed of implementation.

Table 4. Romania: Savings-Investment Balance, 2003-07 (In percent of GDP)

\begin{tabular}{|c|c|c|c|c|c|}
\hline & \multirow[t]{2}{*}{2003} & \multicolumn{2}{|c|}{2004} & \multicolumn{2}{|c|}{2007} \\
\hline & & Auth. 1/ & Program & Auth. 1/ & Program \\
\hline Savings Rate & 18.7 & 19.4 & 19.4 & 20.9 & 21.0 \\
\hline Non-government & 17.5 & 18.9 & 18.0 & 19.4 & 18.4 \\
\hline Private Sector & 18.9 & 19.0 & 18.1 & 18.2 & 17.2 \\
\hline SOEs & -1.4 & 0.0 & 0.0 & 1.3 & 1.3 \\
\hline Government & 1.2 & 0.4 & 1.4 & 1.5 & 2.6 \\
\hline Investment Rate & 24.6 & 25.4 & 24.6 & 27.3 & 26.3 \\
\hline of which: fixed investment & 22.5 & 22.9 & 22.9 & 25.5 & 25.5 \\
\hline Non-government & 21.1 & 21.9 & 21.1 & 22.9 & 21.9 \\
\hline Private Sector & 19.7 & 20.2 & 19.4 & 21.0 & 20.0 \\
\hline SOEs & 1.4 & 1.7 & 1.7 & 1.9 & 1.9 \\
\hline Government & 3.5 & 3.5 & 3.5 & 4.4 & 4.4 \\
\hline Savings-Investment Balance & -5.9 & -6.0 & -5.2 & -6.4 & -5.2 \\
\hline Non-government & -3.6 & -2.9 & -3.1 & -3.5 & -3.4 \\
\hline Private Sector & -0.8 & -1.2 & -1.3 & -2.8 & -2.8 \\
\hline SOEs & -2.8 & -1.8 & -1.8 & -0.7 & -0.7 \\
\hline Government & -2.3 & -3.1 & -2.1 & -2.9 & -1.8 \\
\hline Current Account Balance & -5.9 & -6.0 & -5.2 & -6.4 & -5.2 \\
\hline External Debt & 34.6 & 35.0 & 33.2 & 39.3 & 33.3 \\
\hline Public Debt 2/ & 19.7 & 19.5 & 18.6 & 22.1 & 19.7 \\
\hline Public Debt 3/ & 26.2 & 27.5 & 26.6 & 28.4 & 26.0 \\
\hline
\end{tabular}

Sources: Romanian Authorities and Fund staff estimates.

1/ The projection in this column reflects the authorities' original fiscal target for the general government deficit of 3 percent of GDP.

2/ Excluding government guarantees.

3/ Including government guarantees. 


\section{Box 1. Medium-Term Current Account Developments}

Romania's sustainable current account deficit is now estimated somewhat higher than at the previous Article IV consultation. Non-debt-creating inflows are projected at $3 \frac{1}{2}$ percent of GDP on average over the next five years (2004-08), reflecting the large-scale privatization projects in the pipeline (BCR, Petrom, the two gas distribution companies, estimated conservatively at US\$1.1 billion), rising greenfield FDI as EU accession approaches, and the utilization of pre-accession funds. A current account deficit of $5 \frac{1}{4}$ percent of GDP, in line with the recent trends and projections for the region (Figure 12), would cut the gross external debt-to-GDP ratio by 1 percentage point (Appendix IV). Under this scenario, Romania's public debt would slightly decline relative to GDP (Appendix V), reducing further external vulnerability.

The analysis is sensitive to assumptions about FDI and growth: with a lower level of FDI, close to its 1998-2003 average, and GDP growth of only 3 percent, the debt-toGDP-stabilizing current account deficit would be $4 \frac{1}{4}$ percent of GDP. Some of the adjustment would be

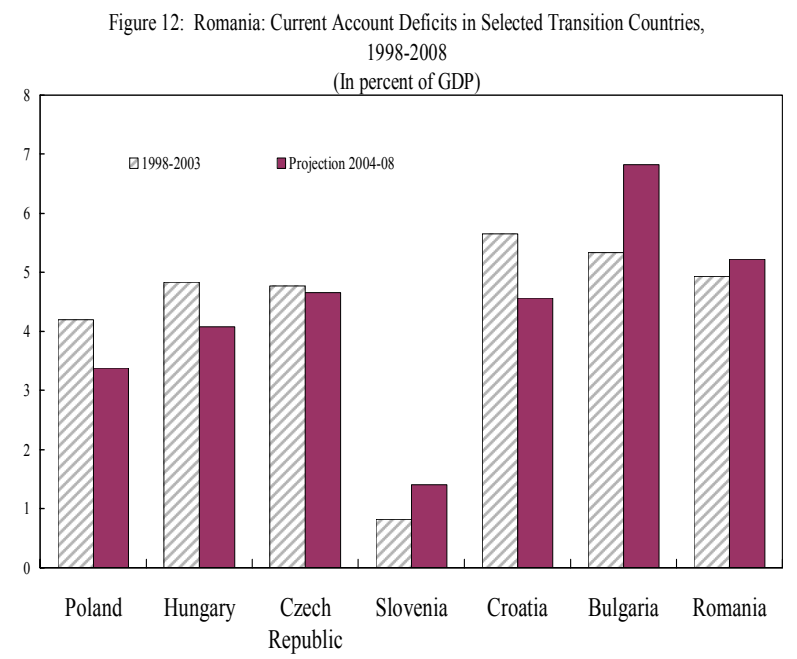
automatic as FDI-related imports would decline, while policies would need to address the remainder. If the debt-to-GDP ratio were limited to 40 percent, the sustainable current account deficit would be $43 / 4$ percent of GDP, or $1 / 2$ percentage point less than in the baseline projection.

The analysis is less sensitive to exchange rate developments. Even a large real effective depreciation of 15 percent (such as triggered by the 1999 balance of payments crisis, about a half of which was reversed in 2000) would increase the external debt to GDP ratio to 45 percent, which, based on available evidence, would not put external sustainability at risk. 


\section{Box 2. Romania's Medium-Term Growth Potential}

The targeted GDP growth rate appears feasible, assuming that macroeconomic stabilization and structural reforms continue. After mediocre performance over the 1990 s, Romania's GDP growth averaged about $4 \frac{1}{2}$ percent in 2000-03. The gradually accelerating privatization and restructuring process increased total factor productivity (TFP) by shedding surplus labor, importing FDI-related know-how, and improving managerial practices. Macroeconomic stabilization and the improved prospects for EU accession attracted strong investment in a number of industries and services. Employment, which fell throughout the 1990s, continued to drop, but more slowly.

Looking ahead, an increase in fixed capital formation relative to GDP by $23 / 4$ percentage points over the next five years, consistent with a somewhat higher current account deficit, could push up capital's contribution to output growth to almost 3 percentage points. Recent investment trends and the appeal of EU accession bode well for Romania: Growth Accounting such prospects. Privatization and SOE restructuring could sustain annual productivity gains above 2 percent. Employment is expected to stabilize just below its present level, with job creation in the private sector broadly matching the layoffs from further restructuring.

\section{B. Fiscal Policy Over the Medium Term}

16. The government's medium-term budget plans are driven by the intention to cut taxes and increase investment (Text Table 5). The authorities envisage a revenue loss relative to GDP of about 1.3 percentage points by 2007 as a result of cuts in social security contributions, a planned VAT rate differentiation and lower dividends as privatization progresses. The loss would be partly offset by higher excises and improved collections. Investment would increase relative to GDP by about 1 percentage point, while spending on maintenance and operating expenditure would decline substantially. 
Table 5. Romania: Fiscal Adjustment, 2003-07

\begin{tabular}{|c|c|c|c|}
\hline & 2003 & \multicolumn{2}{|c|}{2007} \\
\hline & \multicolumn{3}{|c|}{ (In percent of GDP) } \\
\hline & Est. & Authorities & S taff \\
\hline Total Revenue and Grants & 30.0 & 28.7 & 29.4 \\
\hline Total Expenditure & 32.3 & 31.7 & 31.1 \\
\hline Primary Expenditure & 30.2 & 29.6 & 29.2 \\
\hline Primary Current Expenditure & 26.5 & 25.1 & 24.7 \\
\hline Capital Expenditure & 3.5 & 4.4 & 4.4 \\
\hline Overall Balance & -2.3 & -3.0 & -1.8 \\
\hline
\end{tabular}

Source: Romanian authorities and Fund staff projections.

\section{Staff advised against tax cuts, except for social security taxes, and supported} improvements in revenue administration. In light of the need to maintain a tight budget balance and increase expenditure on EU accession-related items, staff felt that plans for broadening the scope of goods subject to the reduced VAT rate were unwarranted. Moreover, the proposed tax relief for reinvested profits would be unnecessary and costly alongside the already well-functioning scheme for accelerated depreciation. Staff supported the reduction in the number of income tax brackets from five to three, but advised that the reform be revenue neutral. Further cuts in the still high social security taxes were appropriate, but they needed to be compensated by broadening the tax base. Staff welcomed progress in implementing the FAD TA recommendations in tax administration.

\section{The authorities' medium-term expenditure plans included reducing subsidies} and increasing sharply spending on motorway construction. They acknowledged that spending on various forms of subsidies needed to be cut in line with their commitment to reduce state aid in the run-up to EU accession and improve the financial performance of SOEs. In response to staff's concerns about fiscal commitments created by the recent decisions to start numerous motorway projects, the authorities agreed to seek World Bank advice on prioritizing the program. Moreover, to address concerns about awarding a large motorway project without a competitive bidding procedure, the authorities hired a consultant, financed by the World Bank, to assess the fairness of the unit prices in the contract.

\section{The authorities agreed with staff on the need for further reform of the pension}

system. The current pay-as-you-go system could be improved by broadening the tax base, accelerating the schedule for increasing the statutory retirement age, and equalizing the retirement age for men and women, as recommended by the World Bank (Box 3). Staff also advised against a new scheme for compensating specific categories of pensioners for lowerthan-average adjustments during 1990-98 (so-called recorrelation), as most of their pensions had been granted on a more generous accrual formula than under the current, reformed system. The mission discussed the authorities' plans for introducing a second, fully-funded pillar in January 2006, which was subsequently postponed to 2008. In staff's view, the stable projected old-age dependency ratio over the next 10-15 years provided a window of opportunity for such a reform, before the aging of the population made the reform more difficult. 


\section{Box 3. Romania's Pension System}

The pension system has recently incurred only small deficits, but further reform is important for keeping the deficits under control. Stable spending of about 7 percent of GDP and a deficit below 1 percent of GDP over the last few years reflected a low and declining replacement rate, which compensated for a high and rising dependency ratio. Staff project that the deficit could increase relative to GDP by almost 1 percentage point by 2008, reflecting: (i) the authorities' intention to further reduce the social security tax rate by 5 percentage points; (ii) limited scope for further decline in the replacement ratio; and (iii) an increase in the dependency ratio as employment remains flat while the number of retirees continues to increase (Text Table 6). In the long run, the Pension Fund balance will be affected by two opposing forces. On one hand, the low replacement rate could create pressures to increase spending, given discretion in annual pension adjustments. On

Table 6. Romania: Pension Fund Medium-term Projection

\begin{tabular}{lrrrr}
\hline & 2002 & \multicolumn{1}{c}{2004} & 2008 & $2008 / 2002$ \\
\hline & \multicolumn{5}{c}{ (in percent of GDP) } \\
Total revenue & 6.3 & 5.9 & 5.1 & -1.1 \\
Total expenditure & 7.1 & 7.1 & 6.9 & -0.2 \\
Deficit & -0.9 & -1.1 & -1.8 & -0.9 \\
Replacement ratio (state pensioners) & 31.1 & 28.6 & 28.6 & -2.5 \\
Dependency ratio (state pensioners) & 103.7 & 104.6 & 106.9 & 3.2 \\
\hline
\end{tabular}

Source: Staff projection.

the other hand, the fact that the pension system's dependency ratio is five times higher than the old-age dependency ratio suggests that the current pension fund balance reflects a transition-induced early retirement surge.

\section{Wage Policy}

\section{Staff and the authorities agreed that prudent wage policies are critical for} maintaining macroeconomic stability. Staff emphasized that wage policy was one of the pillars of the disinflation strategy, and that wage and employment controls in SOEs would need to remain in place until hard budget constraints were firmly established. The framework of multi-layered collective contracts, while helpful in preserving social peace, needed to be modified to ensure that labor contracts reflect specific conditions in each enterprise.

Moreover, further real increases in the minimum wage, which is now high compared to the economy-wide average wage, would be detrimental to competitiveness. The authorities saw the minimum wage tool as an instrument to ensure a fairer distribution between labor and capital, but also acknowledged the importance of wage policy for macroeconomic management. 


\section{Monetary and Exchange Rate Policies}

21. The authorities believed strongly that the gradual disinflation strategy had been and remained appropriate. With the strong persistence of inflation (Selected Issues, Chapter II) and the need for further adjustment in relative prices, the risks of rapid disinflation would exceed its benefits. The strategy of anchoring monetary policy on the exchange rate (see 11 above), restricting short-term capital inflows, and keeping interest rates high had proved effective in reducing inflation over the past three years. Staff agreed with the authorities that such a framework could deliver further disinflation until the introduction of inflation targeting planned for 2005. Recent favorable developments in respect to inflation and the excess supply in the foreign exchange market suggested that the next step of the NBR might be to cut the policy interest rate, which at $231 \frac{1}{2}$ percent was high relative to the inflation rate of $12 \frac{1}{2}$ percent. While such a cut was unlikely to affect domestic demand owing to low interest rate sensitivity of demand for credit, it would reduce appreciation pressures on the leu. No change in the targeted depreciation rate seemed necessary, as competitiveness has remained appropriate (see 9 above, and Figures 4-6), but developments in competitiveness and export performance would need to be carefully monitored.

\section{The NBR has long considered inflation targeting (IT) as the appropriate medium-term monetary policy framework for Romania and intended to adopt it in} 2005. The Bank wanted to be able to credibly commit to focusing on inflation, shifting the responsibility for the external current account to fiscal and income policies. Moreover, IT was seen as conducive to further strengthening NBR independence, which the Bank occasionally felt was under pressure. The NBR also considered that the various forms of explicit fixed exchange rate regimes would be overly risky and would expose Romania, in the absence of strong fiscal and wage policies, to volatile short-term capital flows. This left IT as the preferred framework.

\section{Staff pointed out that a move to IT would require strong efforts to complete} technical preparations and clarify the policy framework. Staff welcomed the authorities' decision to approve amendments to the NBR law to facilitate its independence in line with the relevant EU acquis. However, an MFD TA mission on IT indicated that substantial technical work was still needed in the areas of information gathering, analysis and policy decision-making procedures. Staff also noted that the challenge of implementing IT reflected difficulties in estimating the transmission of interest rates to activity and inflation.

Consequently, the NBR would need to continue to rely on exchange rate interventions to control inflation. In contrast to the use of the exchange rate as an intermediate policy objective, the exchange rate path would need to be regularly adjusted in line with the evolving inflation outlook. 


\section{E. Financial Sector Policies}

24. While the authorities believed that the financial system was strong, they remain vigilant. In line with the FSAP recommendations, staff advised the authorities to stress-test banks' portfolios periodically for credit, foreign exchange, interest rate, and interbank risks, by simulating a broad range of shocks, which the authorities accepted. Other recommendations included measures for ensuring a safe introduction of the RTGS payment system, and improving the oversight of the nascent capital market. The authorities are also drafting, with assistance from the World Bank, a new capital market law.

25. The FSAP also noted the risks created by rapid credit growth, an issue that staff and the authorities had discussed since late 2002. The authorities considered that banks' capital adequacy ratios, exceeding BIS standards by large margins, provided comfort, as did the fact that about half of the banking sector was owned by reputable foreign banks. The stock of bank credit to the nongovernment sector was also low (16 percent of GDP at end2003), and growth in credit reflected the improved confidence in macroeconomic stabilization. Staff, however, expressed concerns about the massive flows of consumer and mortgage credit, which were raising domestic demand, slowing disinflation, and pushing the current account deficit beyond prudent limits. Furthermore, credit screening could deteriorate with such a rapid expansion, a problem aggravated by the lack of a credit bureau.

26. The authorities agreed that the macroeconomic and prudential risks required a policy response. They noted that the NBR had tightened eligibility criteria for consumer and mortgage loans in January 2003. The Insurance Supervision Commission had imposed limits on insurers' retained exposure on consumer and mortgage loans. ${ }^{4}$ The NBR also prompted commercial banks to organize a credit bureau, now under way. The measures had had a noticeable effect in slowing consumer credit growth in February and March. Recently, the authorities have also extended the eligibility-tightening measures to non-bank financial and retail sectors and drafted a truth-in-lending act to improve consumer awareness of credit terms. Nevertheless, they indicated willingness to implement additional measures if necessary, including imposing mandatory reporting by all creditors to the credit bureau. Together with MFD staff, they are preparing a study on the macroeconomic and prudential risks of rapid credit growth, following up on the 2003 FSAP recommendations.

\section{F. Structural Policies and the Trade Regime}

\section{The authorities saw structural reforms as crucial for continuing rapid GDP} growth but expressed concerns about possible adverse social effects. The Ministry of Economy and Commerce, which attributed delays in the energy sector privatization to weak market conditions, intended now to accelerate this process. The authorities also acknowledged the need for continuing gas price adjustments, reversing their previous

${ }^{4}$ See 6 of the MEFP. 
reluctance motivated by social concerns. On the privatization of Romgaz, the country's main natural gas extraction company, they expressed concerns given its large market share, and indicated preference for joint ventures with foreign investors. Following discussion with staff, the authorities agreed to consider the privatization option after the successful privatization of Petrom. They also agreed to restructure the mining, railways, and district heating sectors, but pointed to the need for retraining and relocation support for the redundant employees. Staff urged the authorities to come up with realistic budgets for the mining and railway companies, to prevent further accumulation of arrears in these sectors. In the banking sector, the authorities accepted staff's suggestions to accelerate the privatization of the Savings Bank, which will be completed in 2005.

28. Labor markets need to be made more flexible. The new labor code, approved in March 2003, is seen by the business community as overly restrictive in many areas. Particularly at issue are provisions on hiring and firing, the collective contracts, and a new wage-guarantee fund for bankrupt companies. The authorities pointed out that the Labor Code was an attempt to modernize Romania's labor legislation in accordance with ILO principles, while seeking a compromise between the interests of employers and employees. They agreed, however, to address the issues that have raised concerns by amending the law in early 2005, in line with the recommendations of the World Bank (MEFP - 44).

29. Staff welcomed the authorities' efforts to liberalize the trade regime. The average overall effective barriers to trade are small. Owing to the agreement with the EU and other countries, the average effective tariff rate, measured by import duty revenue relative to imports, is very low, only 1.6 percent in 2003 . Trade in industrial products with the EU is free from tariffs, but agricultural tariffs are expected to be eliminated only upon accession. Romania also maintains a large number of Free Trade Agreements with the CEE countries, and is in negotiations with some South East European countries. Staff welcomed the ongoing efforts at liberalizing trade with non-EU partners, including plans to lower the MFN tariffs.

\section{Discussions on a Precautionary SBA}

\section{Romania has requested a new Fund arrangement to strengthen macroeconomic} stabilization and structural reforms in the run-up to EU accession. The authorities' program aims at addressing risks identified in the Article IV discussions, in particular the recent surge in the current account deficit, and the need to bring inflation to single digits. The fiscal consolidation and measures to contain credit growth will play a crucial role in containing domestic demand. Specifically, the fiscal stance of the broad public sector (general government and SOEs) will be tightened relative to GDP by $1 \frac{1 / 4}{4}$ percentage points compared with the 2003 outcome. Credit growth, reflecting measures implemented in early 2004, is expected to slow to about 35 percent in real terms on average, which will reduce the contribution to growth in domestic demand by about 2 percentage points relative to 2003 . As a result, the external current account deficit in 2004 is projected to decline by $3 / 4$ percentage points relative to 2003, to $5 \frac{1}{4}$ percent of GDP, while end-period inflation would be lowered to 9 percent. The saving-investment balance of the private sector would still have scope to 
worsen by about $1 / 2$ percent of GDP, as private consumption and savings are expected to react only gradually to lower growth in credit and wages. On the structural side, the priorities are accelerated privatization, including of the largest company in the country, Petrom, and measures to arrest the accumulation of arrears, and improved governance.

\section{A. Fiscal Policy in 2004}

\section{To support the program objectives, the authorities will amend the 2004 budget.} The supplementary budget, to be approved in July, will reduce the 2004 general government deficit ceiling to no more than 2.1 percent of GDP, compared to 3 percent of GDP in the approved budget ( $\Phi$ 12-14 of the MEFP). Owing to very strong revenue performance, this reduction can be achieved exclusively by saving surplus revenue, which the authorities estimated at 0.9 percent of GDP. Moreover, any revenue surplus over that amount would also be used for reducing the deficit, instead of increasing spending. ${ }^{5}$ Spending on motorway construction under the PPPs will be included in this target unless it satisfies strict criteria established by an FAD TA mission. As one of the measures to eliminate arrears, the budget will provide resources for clearing the health system arrears accumulated in 2002, while expenditure controls in this sector will be strengthened.

\section{Energy price adjustments and wage policy will be the main instruments for} improving the SOEs' financial position. The gas and electricity price adjustments are expected to increase savings relative to GDP by 1.1 percentage point. The wage program for 70 large SOEs is expected to deliver savings relative to GDP of $1 / 2$ percentage point. These savings, partly offset by an increase in SOEs' investment of 0.3 percent of GDP, will improve, with sufficient cushion, the SOEs' S-I balance relative to GDP by about 1 percentage point of GDP.

\section{The authorities will step up the fight against the nonpayment of taxes. Besides} measures to avoid the accumulation of new arrears of SOEs, the authorities accepted that the reduction in tax arrears of the largest private debtors to the budget be a performance criterion under the program (MEFP $\mid 18$ ). Moreover, as a prior action, the authorities initiated bankruptcy procedures against a large private refinery and a number of other companies that had incurred arrears to the budget and suppliers. ${ }^{6}$

\footnotetext{
${ }^{5}$ Based on April data, staff estimates that this surplus could amount to at least 1.1 percent of GDP relative to the approved 2004 budget.

${ }^{6}$ Chapter I of the accompanying Selected Issues paper addresses the issue of arrears in the Romanian economy.
} 


\section{B. Wage Policy}

\section{Wage policy in 2004 will aim at containing domestic demand (MEFP I 21-22) .} Realizing that the sharp statutory minimum wage hike in 2003 was partly responsible for the widening of the current account deficit, the authorities raised it by only 12 percent in January 2004 and committed to keep it constant throughout the year. The adopted SOE wage program requires that net wage growth be contained at 1 percent in real terms, while employment is reduced by 5 percent. However, recent developments have put this program at risk, as labor unions are pushing for a higher minimum wage in a nation-wide collective contract, which would supersede the statutory minimum wage for all medium-size and large enterprises. To address this issue, the government will instruct managers in SOEs and use its influence so that the agreed minimum wage in the national collective contract does not deviate substantially from the statutory minimum wage (MEFP $q 21$ ).

\section{Energy Sector Policies, Privatization and SOE Restructuring}

\section{The authorities are intensifying efforts to improve collections of the main}

utilities. Based on input from the World Bank, the authorities are preparing a strategy for a comprehensive overhaul of district heating, including credible measures to improve collections (MEFP I 25). The policy of disconnections will continue in other utilities.

\section{The program provides for decisive steps to increase domestic gas producers'} price toward import parity by 2007 and adjust electricity prices. In 2004, the final user gas prices will be increased by 5 percent every quarter, which combined with the carryover effects of adjustment in late 2003, will facilitate an increase in domestic producer prices from US\$29/tcm in 2003 to US\$61/tcm in 2004 (MEFP 923 ). The authorities also announced a schedule for further increases in producer prices through 2007. Electricity prices will continue to be adjusted in line with rising costs and to provide an appropriate margin for the return on equity in the distribution sector, to facilitate privatization (MEFP $\$ 24$ ).

37. Privatization in the energy sector will proceed. In cooperation with the World Bank, the mission advised the authorities to relax constraints on the restructuring of Petrom, to improve the chances for its successful privatization. In response, the authorities have shortened the restriction on major reorganizations to four years and eliminated penalties for labor reduction faster than stipulated in the tender documents (MEFP 9 27). They also indicated that they would consider proposals for divesting one refinery before that deadline, and assume all pre-privatization ecological indemnities. For two electricity distributors, the authorities are close to signing a contract, while two other distributors are scheduled to be privatized later in the year (MEFP $\$ 28)$. For the two gas distribution companies, bids are now expected by mid-July.

\section{Staff and authorities discussed measures for keeping the momentum in the} privatization of other large companies. Staff welcomed the plans of the Agency for Privatization to divest all remaining companies in its portfolio, by end-2004, and to reduce employment in such enterprises in advance of privatization if necessary (MEFP 929 ). On the 
$\mathrm{BCR}$, the authorities indicated their intention to proceed with selling their remaining shares as son as possible, in agreement with the EBRD and IFC.

\section{The authorities will initiate decisive restructuring in the large loss-making} mining and railway sectors, responsible for the bulk of arrears to the budget and the energy suppliers. To prevent the incurrence of new arrears in the mining sector, the authorities agreed to close 30 mines and lay off 8,000 miners in two steps in 2004 (MEFP 9 33). The government has also approved an ambitious strategy for restructuring the mining sector. The strategy aims at phasing out state support for the minerals sector by 2007 and for the coal sector by 2010 , reducing employment in the sector by over 40 percent by 2007, in line with commitments to the EU. The World Bank is to provide support for social mitigation schemes in the affected regions. In the railways, staff supported the authorities' proposal to close or give in concessions 3,000 kilometers of low-traffic lines (MEFP - 32). In view of the labor unions' demand for higher wages, the authorities proposed an overall employment reduction of 8,000 positions, about half of which will be layoffs.

\section{Governance Issues}

\section{In cooperation with the World Bank and in response to the EU Commission} recommendations, the authorities are making significant efforts to improve governance. The agreed program includes conditionality for a judicial reform, including strengthening the role of the Superior Council of the Magistrates as the guarantor of judicial independence (MEFP 9 41). Moreover, the law on the declaration of politicians' assets was amended and the office of the special anticorruption prosecutor will be strengthened (MEFP $942-43$ ). The authorities also agreed to implement legislation that would eliminate immunity granted to former cabinet members. To address concerns raised by the recent privatization of a large tobacco company, the authorities have hired a reputable consultancy firm to review the privatization (MEFP 131 ). They will continue with the practice of publishing the list of largest tax nonpayers on a web site and will also regularly publish financial statements of large SOEs on the web. The agreed measures to enforce tax collections against large nonpayers also aim at improving the business climate.

\section{E. Monetary Policy Under the Program}

\section{Monetary policy will focus on lowering inflation to single digits in 2004. The} current exchange-rate-based framework remains appropriate, and the NBR will use both interest rate policy and selective market interventions to steer the exchange rate consistent with the inflation target and a modest real appreciation (MEFP \ 38). However, the authorities will need to remain vigilant in keeping the current account deficit well within safe margins. While fiscal policy would have to lead in this process, the NBR would closely watch credit growth and implement additional measures if necessary (MEFP \ 39). 


\section{F. Vulnerabilities and Balance of Payments Prospects}

42. Vulnerability indicators point to reasonably low short-term risks, but mediumterm prospects depend on persevering with stability-oriented policies and structural reforms. External debt, and public and publicly guaranteed debt-to-GDP ratios are on the low side. The level of official reserves is high relative to money aggregates and short-term debt, and comfortable relative to prospective imports of goods and services (Appendices IV and $\mathrm{V}$ on debt sustainability). Romania's haphazard policy implementation has proved to be the main source of macroeconomic risks. An election-motivated deterioration in the fiscal stance and the postponement of structural reforms in 2004-05 could lead to a loss of market confidence, reversal in disinflation, and current account pressures. These developments would likely be accompanied by rising sovereign spreads, and weakening FDI. While losing access to external financing seems unlikely, the prospects of significantly improving living standards and putting in place the reforms needed to successfully compete in the EU could be pushed back.

\section{In general, the outlook for growth and inflation is expected to be robust to} moderately adverse changes in the external environment. Export resilience despite slow partner demand in 2003 indicates that Romania could weather a slow recovery in the EU.

\section{The balance of payments outlook in $\mathbf{2 0 0 4}$ and over the medium term appears} favorable. The improved confidence in the economy in the run-up to the EU accession will spur an increase in FDI and business confidence. Foreign borrowing will be reduced in line with the lower budget deficit.

45. Banking system vulnerability remains low for the immediate future; however, the recent speed of credit expansion has been excessive. The overall indebtedness of the private sector and its exposure to foreign-currency-denominated credit (both to domestic banks and foreign creditors) are low compared with other accession countries. Should, however, the recent excessive pace of credit expansion not abate, the authorities would need to implement additional measures to protect the solvency of banks.

46. Staff is presently completing a safeguards assessment with respect to the precautionary SBA. Preliminary conclusions do not indicate serious vulnerabilities. Moreover, the NBR has considerably strengthened its safeguards framework since the 2002 assessment that was conducted under the previous SBA.

\section{Access, Phasing, Monitoring, And Other Issues}

47. The authorities intend to treat the proposed 24-month arrangement as precautionary. The length of the arrangement reflects the need to implement structural reforms, in line with EPA recommendations. Total access of SDR 250 million (24.3 percent of quota) would be made available in nine purchases (Table 13). The precautionary nature and the low access level reflect the absence of an immediate balance of payments need. 


\section{Front-loaded conditionality ensures the implementation of crucial} macroeconomic and structural policies, in line with recommendations in the Ex-post Assessment. The macroeconomic objectives of reducing inflation and containing the current account deficit are addressed, in addition to conventional quantitative PCs, with a quantitative PC on the wage bill of SOEs and several structural measures to improve the financial performance of the energy sector. The important issue of arrears is addressed via quantitative targets for collection rates of the main utilities, targets for tax arrears, and other arrears of SOEs, and structural conditionality on reforms in the mining, railways, and district heating sectors, developed in close coordination with the World Bank. The Bank has also considered that more frequent Fund reviews could be more effective in implementing energy price reforms. Reflecting the Executive Directors' views expressed on EPA, the program includes conditionality on governance issues, which builds upon the work of the World Bank and the authorities' discussions with the EU Commission. A broad consensus has developed that Fund conditionality would be most effective for a timely implementation of these measures.

49. Reviews will be conducted on a quarterly basis. In addition to the main financial performance indicators, they will assess progress in implementing the structural elements of the program.

\section{Staff Appraisal}

\section{Romania's notable progress in addressing long-standing policy deficiencies has} improved its macroeconomic performance. After the "lost decade" of the 1990s, Romania has gone a long way toward cutting its budget and broader public sector deficits The resulting reduction in macroeconomic imbalances, together with a strong improvement in competitiveness stemming from the 1999 devaluation, has boosted confidence and private investment, leading to a strong pick-up in growth. Inflation has fallen steadily and both the saving and investment rates have risen. Declining unit labor costs and the considerable resilience of exports to the slowdown in the main trading partner economies suggest favorable supply conditions.

51. However, the structural reform agenda remains large. Romania's share of the public sector in the economy is still the largest among accession countries. While recently the Agency for Privatization successfully accelerated the privatization of enterprises in its portfolio, privatization projects in the energy sector have been delayed, and no project has yet been completed. The financial performance of SOEs remains a problem, particularly in the railways and mining sectors. Weak governance and corruption problems continue to be significant obstacles for larger FDI.

52. Macroeconomic stabilization needs to be completed. To proceed with the stabilization that relies on exchange rate policy, the current account deficit has to be kept well within safe margins. Fiscal policy is crucial for this purpose and, over the medium-term, 
the general government budget deficit should be kept below 2 percent of GDP. This is particularly important because neither low inflation nor monetary policy credibility has yet been established, while wage policies have often slipped.

\section{Efforts to contain the general government deficit will need to be pursued in} tandem with measures to improve the structure of revenues and expenditures. Social security contribution rates need to be lowered further; meanwhile, excise taxes will need to increase gradually to EU levels and tax collection should be strengthened further.

Expenditures must be carefully prioritized to make room for accession-related investment spending.

\section{Completing the task of stabilization hinges crucially on progress in imposing} hard budget constraints on the state-owned enterprise sector. Large and volatile losses of these enterprises, particularly in the energy sector, mines, and railways, have undermined previous stabilization efforts. In the energy sector, the emphasis must be on raising gas prices to import parity, and timely adjustment of electricity and heating prices in line with costs. The fight against the nonpayment of utility bills and tax arrears should also continue. Significant downsizing of the loss-making mining and railway sectors should be accompanied by enhancing the social safety net and programs for retraining and relocation.

\section{Prudent wage policies are critical for maintaining macroeconomic stability.}

Every effort is needed to prevent that collective contracts derail the SOEs wage program and invalidate the government's decision on the statutory minimum wage. Moreover, further real increases in the minimum wage, which is now high compared to the economy-wide average wage, should be avoided, as they would aggravate demand pressures and harm Romania's competitiveness. Employment and wage controls in SOEs need to continue.

\section{The authorities' plans for privatization need to be pursued vigorously. It is} encouraging that the authorities plan to sell or close by end-2004 most of the companies remaining in the portfolio of the Agency for Privatization. In the energy sector, the privatization of the largest company in the country, Petrom, and several distribution companies is crucial.

57. The Labor Code needs to be overhauled to increase labor market flexibility. The recent favorable growth performance reflected a flexible labor market, but the new Labor code includes many regulations that take steps in the wrong direction and have adversely affected the flexibility of the labor market. Staff welcomes the authorities' willingness to amend the law.

58. The authorities are aware that comprehensive governance reforms are necessary for further improving the business climate. Catching up with other EU accession countries requires stepping up the fight against corruption, perceived as a key impediment to a better business climate. Reform of the judiciary system to improve its effectiveness and independence, in particular, stands out. Romania must also demonstrate that it has 
established an efficient bankruptcy mechanism, a crucial element of a fully functioning market economy.

59. The current monetary policy of guiding the exchange rate consistent with the inflation target and real appreciation in line with the differentials in sectoral productivity remains appropriate for the near future. This guidance is achieved with market interventions combined with interest rate policy. Recent NBR measures seem to have moderated consumer credit growth; nevertheless, the authorities will need to strengthen bank supervision and strictly enforce the new regulations on consumer and mortgage lending.

60. With further progress in stabilization and the completion of technical preparations, it will be appropriate to move to an IT framework for monetary policy. The introduction of IT needs to be well prepared by establishing the institutional, operational, and analytical prerequisites for its success. The strengthening of the NBR's independence, accomplished by the amendments to the NBR law in June 2004, is an important step in this direction. However, extensive changes in the structure of information gathering, analysis, and monetary policy decision-making remain to be accomplished. In case of delays, the authorities should consider postponing the switch to IT. They should also consider introducing joint announcements by the NBR and the government of the annual inflation target, to better coordinate monetary, fiscal, and incomes policies and increase the credibility of the target.

61. The financial system appears healthy, although risks from rapid credit growth cannot be ignored. Financial soundness indicators suggest that banks can withstand considerable stress as they are liquid and well capitalized. However, in the context of exceptionally rapid credit growth, enhanced on-site supervision is a must, together with a systematic assessment of risk exposure through stress-testing of portfolios. While the overall exposure of the private sector to foreign currency risk is currently limited, additional measures will be needed should rapid growth in foreign currency loans re-emerge.

\section{In staff's view, the authorities program presented in the attached Letter of} Intent and the Memorandum of Economic and Financial Policies, includes the policies necessary to achieve further progress in macroeconomic stabilization. Staff therefore recommends that the authorities' request for the SBA, which they intend to treat as precautionary, be approved.

63. It is suggested that the Article IV Consultation with Romania be held on the twentyfour-month cycle, subject to the provisions of the decision on consultation cycles approved by the Board on July 15, 2002. 
Table 1. Romania: Selected Economic and Financial Indicators, 1999-2004

\begin{tabular}{|c|c|c|c|c|c|c|}
\hline & 1999 & 2000 & 2001 & 2002 & 2003 & 2004 \\
\hline & & & & & & Proj. \\
\hline \multicolumn{7}{|l|}{ Real economy (change in percent) $1 /$} \\
\hline Real GDP & -1.2 & 2.1 & 5.7 & 5.0 & 4.9 & 5.0 \\
\hline Final domestic demand & -2.9 & 2.1 & 6.9 & 3.5 & 7.3 & 6.0 \\
\hline CPI (end of period) & 54.8 & 40.7 & 30.3 & 17.8 & 14.1 & 9.0 \\
\hline CPI (period average) & 45.8 & 45.7 & 34.5 & 22.5 & 15.3 & 11.5 \\
\hline Unemployment rate (end of period; percent) & 11.8 & 10.5 & 8.6 & 8.1 & 7.2 & 6.5 \\
\hline Gross national saving (percent of GDP) & 11.9 & 15.6 & 17.0 & 20.1 & 18.7 & 19.6 \\
\hline Gross domestic investment (percent of GDP) & 16.1 & 19.5 & 22.6 & 23.5 & 24.6 & 24.8 \\
\hline \multicolumn{7}{|l|}{ Public finance (general government, percent of GDP) } \\
\hline Overall balance & -3.6 & -4.0 & -3.2 & -2.6 & -2.3 & -2.1 \\
\hline Primary balance & 2.4 & 0.9 & 0.6 & 0.4 & -0.2 & 0.0 \\
\hline Total public debt (in percent of GDP) 2/ & 30.5 & 29.9 & 27.4 & 26.8 & 26.2 & 26.5 \\
\hline \multicolumn{7}{|l|}{ Money and credit (end of year, percent change) } \\
\hline Real domestic credit 3/ & -7.6 & 9.9 & 27.9 & 33.1 & 55.4 & 21.4 \\
\hline Broad money & 44.9 & 38.0 & 46.2 & 38.1 & 23.3 & 27.2 \\
\hline \multicolumn{7}{|l|}{ Interest rates (percent) } \\
\hline NBR interest rates (end of period) 4/ & 88.7 & 60.1 & 39.9 & 21.5 & 23.4 & ... \\
\hline Treasury bill rate (end of period) & 104.8 & 59.4 & 38.4 & 17.4 & 18.4 & ... \\
\hline \multicolumn{7}{|l|}{ Balance of payments (percent of GDP) } \\
\hline Trade balance & -3.5 & -4.5 & -7.4 & -5.7 & -8.0 & -7.0 \\
\hline Current account balance & -4.0 & -3.9 & -5.5 & -3.4 & -5.9 & -5.2 \\
\hline External debt & 25.6 & 28.7 & 30.7 & 34.3 & 34.6 & 33.2 \\
\hline Official reserves (end-year, US\$ million) & 2,472 & 3,466 & 5,090 & $6,975.0$ & $7,994.0$ & $9,664.0$ \\
\hline Reserve cover (months of prospective imports) & 2.1 & 2.5 & 3.2 & 3.5 & 3.3 & 4.2 \\
\hline \multicolumn{7}{|l|}{ Exchange rate } \\
\hline Lei per US\$ (end of period) & 18,250 & 25,926 & 31,597 & 33,500 & 33,013 & $\ldots$ \\
\hline NEER appreciation $(+)$ (annual average in percent) & -39.8 & -22.8 & -22.3 & -14.4 & -11.1 & $\ldots$ \\
\hline REER appreciation $(+)$ (CPI-based, annual average in percent) & -15.0 & 9.3 & 1.5 & 2.6 & 0.4 & $\ldots$ \\
\hline REER appreciation $(+)(\mathrm{CPI}$ excl. admin. prices, annual average in percent) & $\ldots$ & 6.0 & 1.8 & 1.0 & 0.0 & $\ldots$ \\
\hline REER appreciation (+) (ULC-based, annual average in percent) & -21.8 & -0.3 & -0.9 & -6.7 & -5.6 & $\ldots$ \\
\hline
\end{tabular}

Sources: Romanian authorities; and Fund staff estimates and projections.

1/ National accounts data 1998-2004 are based on ESA95 guidelines. Revision was implemented in 2002.

2/ Including domestic public debt and external public debt (public and publicly guaranteed).

3/ Credit to nongovernment sector. From 1999 onwards, weighted average of real lei credit growth and U.S. dollar-measured foreign currency credit growth.

4/ NBR deposit auction interest rate. 
Table 2. Romania: Balance of Payments, 2003-04

(In millions of U.S. dollars unless indicated otherwise)

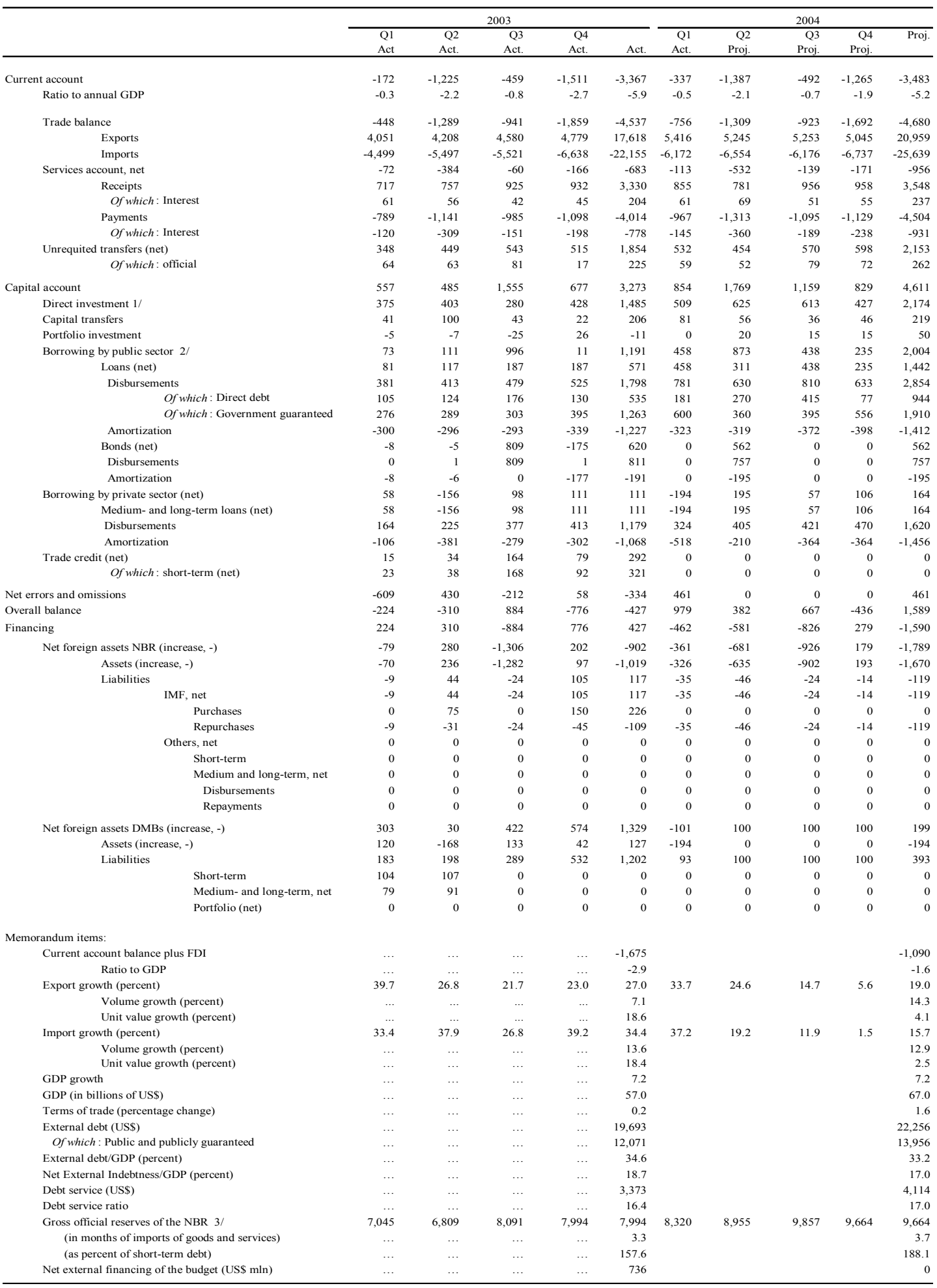

Sources: Romanian authorities; and Fund staff estimates.

1/ Includes 2004Q1 privatization proceeds from BCR and the two Distrigaz companies.

2/ Includes public enterprises.

$3 /$ Includes gold. 
Table 3. Romania: Summary of Consolidated General Government, 2000-2004

\begin{tabular}{|c|c|c|c|c|c|c|c|c|c|c|c|c|}
\hline & \multirow{2}{*}{$\begin{array}{l}2000 \\
\text { Actual }\end{array}$} & \multirow{2}{*}{$\begin{array}{c}2001 \\
\text { Actual }\end{array}$} & \multirow{2}{*}{$\begin{array}{c}2002 \\
\text { Actual 3/4/ }\end{array}$} & \multirow{2}{*}{$\begin{array}{c}2003 \\
\text { Actual 4/ }\end{array}$} & \multicolumn{2}{|c|}{2004} & \multirow{2}{*}{$\begin{array}{l}2000 \\
\text { Actual }\end{array}$} & \multirow{2}{*}{$\begin{array}{c}2001 \\
\text { Actual }\end{array}$} & \multirow{2}{*}{$\begin{array}{c}2002 \\
\text { Actual 3/ 4/ }\end{array}$} & \multirow{2}{*}{$\begin{array}{c}2003 \\
\text { Actual 4/ }\end{array}$} & \multicolumn{2}{|c|}{2004} \\
\hline & & & & & Budget 4/ & $\begin{array}{c}\text { Staff } \\
\text { estim. 4/5/ } \\
\end{array}$ & & & & & Budget 4/ & $\begin{array}{c}\text { Staff } \\
\text { estim. 4/ 5/ } \\
\end{array}$ \\
\hline & \multicolumn{6}{|c|}{ (In billion lei) } & \multicolumn{6}{|c|}{ (In percent of GDP) } \\
\hline Total revenue and grants & 251,095 & 351,741 & 449,012 & 566,727 & 651,975 & 669,798 & 31.2 & 30.1 & 29.7 & 30.0 & 29.1 & 29.9 \\
\hline Current & 249,945 & 351,108 & 447,645 & 564,314 & 645,826 & 663,698 & 31.1 & 30.1 & 29.6 & 29.8 & 28.8 & 29.6 \\
\hline Tax & 235,048 & 326,699 & 418,166 & 532,482 & 612,821 & 633,154 & 29.2 & 28.0 & 27.6 & 28.2 & 27.3 & 28.2 \\
\hline Profits & 20,334 & 22,206 & 30,190 & 44,167 & 49,610 & 56,809 & 2.5 & 1.9 & 2.0 & 2.3 & 2.2 & 2.5 \\
\hline Wages and salaries & 26,998 & 37,203 & 41,661 & 53,541 & 64,921 & 66,332 & 3.4 & 3.2 & 2.8 & 2.8 & 2.9 & 3.0 \\
\hline Social security & 86,557 & 125,106 & 161,867 & 186,147 & 215,453 & 211,502 & 10.8 & 10.7 & 10.7 & 9.8 & 9.6 & 9.4 \\
\hline Other direct taxes & 8,081 & 13,025 & 14,637 & 17,450 & 21,900 & 20,373 & 1.0 & 1.1 & 1.0 & 0.9 & 1.0 & 0.9 \\
\hline VAT & 50,439 & 73,604 & 104,495 & 136,357 & 156,189 & 158,673 & 6.3 & 6.3 & 6.9 & 7.2 & 7.0 & 7.1 \\
\hline Customs & 8,702 & 9,038 & 9,362 & 12,882 & 13,824 & 14,647 & 1.1 & 0.8 & 0.6 & 0.7 & 0.6 & 0.7 \\
\hline Excise & 20,636 & 27,293 & 32,434 & 60,408 & 68,915 & 81,738 & 2.6 & 2.3 & 2.1 & 3.2 & 3.1 & 3.6 \\
\hline Other indirect taxes & 13,301 & 19,224 & 23,521 & 21,530 & 22,009 & 23,079 & 1.7 & 1.6 & 1.6 & 1.1 & 1.0 & 1.0 \\
\hline Nontax & 14,897 & 24,409 & 29,479 & 31,832 & 33,005 & 30,544 & 1.9 & 2.1 & 1.9 & 1.7 & 1.5 & 1.4 \\
\hline Capital & 826 & 387 & 682 & 1,524 & 1,342 & 1,276 & 0.1 & 0.0 & 0.0 & 0.1 & 0.1 & 0.1 \\
\hline Grants & 325 & 246 & 685 & 889 & 4,807 & 4,824 & 0.0 & 0.0 & 0.0 & 0.0 & 0.2 & 0.2 \\
\hline Total expenditure & 283,351 & 389,321 & 488,523 & 610,603 & 716,274 & 716,904 & 35.3 & 33.4 & 32.3 & 32.3 & 31.9 & 32.0 \\
\hline Current & 255,275 & 351,794 & 438,494 & 542,261 & 635,777 & 636,407 & 31.8 & 30.1 & 29.0 & 28.7 & 28.3 & 28.4 \\
\hline Wages and salaries & 43,894 & 58,174 & 73,555 & 90,888 & 107,159 & 107,289 & 5.5 & 5.0 & 4.9 & 4.8 & 4.8 & 4.8 \\
\hline Materials and operating expenditures & 56,503 & 81,119 & 107,295 & 143,612 & 145,755 & 146,255 & 7.0 & 6.9 & 7.1 & 7.6 & 6.5 & 6.5 \\
\hline $\mathrm{o} / \mathrm{w}$ : health insurance func & 24,997 & 36,779 & 47,687 & 61,048 & 63,289 & 63,289 & 3.1 & 3.2 & 3.2 & 3.2 & 2.8 & 2.8 \\
\hline Reserve & & & & & 901 & 901. & $\ldots$ & 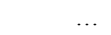 & & $\ldots$ & 0.0 & 0.0 \\
\hline Interest $1 /$ & 38,973 & 44,610 & 45,351 & 40,229 & 46,992 & 46,992 & 4.8 & 3.8 & 3.0 & 2.1 & 2.1 & 2.1 \\
\hline Subsidies and transfers & 115,905 & 167,891 & 212,293 & 267,532 & 334,970 & 334,970 & 14.4 & 14.4 & 14.0 & 14.1 & 14.9 & 14.9 \\
\hline Subsidies & 17,581 & 24,294 & 29,900 & 43,566 & 47,781 & 47,781 & 2.2 & 2.1 & 2.0 & 2.3 & 2.1 & 2.1 \\
\hline Transfers & 98,324 & 143,597 & 182,393 & 223,965 & 287,189 & 287,189 & 12.2 & 12.3 & 12.1 & 11.8 & 12.8 & 12.8 \\
\hline$o / w:$ Pensions & 53,579 & 79,578 & 102,185 & 118,182 & 144,141 & 144,141 & 6.7 & 6.8 & 6.8 & 6.3 & 6.4 & 6.4 \\
\hline Capital & 24,482 & 36,549 & 48,864 & 66,226 & 78,621 & 78,621 & 3.0 & 3.1 & 3.2 & 3.5 & 3.5 & 3.5 \\
\hline Lending minus repayments & 3,594 & 978 & 1,165 & 2,116 & 1,877 & 1,877 & 0.4 & 0.1 & 0.1 & 0.1 & 0.1 & 0.1 \\
\hline Overall balance (cash, including grants) & $-32,256$ & $-37,580$ & $-39,512$ & $-43,877$ & $-64,299$ & $-47,106$ & -4.0 & -3.2 & -2.6 & -2.3 & -2.9 & -2.1 \\
\hline Financing & 28,322 & 36,948 & 34,818 & 23,631 & 64,299 & 47,106 & 3.5 & 3.2 & 2.3 & 1.2 & 2.9 & 2.1 \\
\hline Domestic & $-1,913$ & 10,730 & 4,383 & $-13,303$ & 19,884 & 13,031 & -0.2 & 0.9 & 0.3 & -0.7 & 0.9 & 0.6 \\
\hline External & 22,575 & 20,104 & 22,826 & 30,636 & 38,215 & 20,275 & 2.8 & 1.7 & 1.5 & 1.6 & 1.7 & 0.9 \\
\hline Privatization proceeds & 5,062 & 3,460 & 5,532 & 4,277 & 5,000 & 12,600 & 0.6 & 0.3 & 0.4 & 0.2 & 0.2 & 0.6 \\
\hline Bank asset recoveries & 2,597 & 2,654 & 2,077 & 2,021 & 1,200 & 1,200 & 0.3 & 0.2 & 0.1 & 0.1 & 0.1 & 0.1 \\
\hline Discrepancy $2 /$ & $-3,934$ & -632 & $-4,694$ & $-20,246$ & 0 & 0 & -0.5 & -0.1 & -0.3 & -1.1 & 0.0 & 0.0 \\
\hline Memorandum i & & & & & & & & & & & & \\
\hline Primary expenditure 4 / & 244,167 & 344,711 & 443,172 & 570,374 & 669,282 & 669,912 & 30.4 & 29.5 & 29.3 & 30.2 & 29.8 & 29.9 \\
\hline Primary current expenditure $4 /$ & 216,302 & 307,184 & 393,143 & 502,032 & 588,785 & 589,415 & 26.9 & 26.3 & 26.0 & 26.6 & 26.2 & 26.3 \\
\hline Primary balance (cash, including grants) 3/ & 6,928 & 7,030 & 5,839 & $-3,647$ & $-17,307$ & -114 & 0.9 & 0.6 & 0.4 & -0.2 & -0.8 & 0.0 \\
\hline Nominal GDP (billions lei) & 803,773 & $1,167,243$ & $1,512,617$ & $1,890,778$ & $2,243,160$ & $2,243,160$ & 803,773 & $1,167,243$ & $1,512,617$ & $1,890,778$ & $2,243,160$ & $2,243,160$ \\
\hline
\end{tabular}

Sources: Ministry of Public Finance; and Fund staff estimates.

$1 /$ Including called-up loan guarantees.

2/ Difference between financing and the deficit of the consolidated general government.

3/ As the 2003 budget incorporated various extrabudgetary revenues and expenditures, the budgets for 2002 and 2003 are not fully comparable. On a comparable basis, they are by 0.3 percent of G 4/ Including National Administration of Roads (AND).

5/ Owing to the merger between the privatization agency (APAPS) and the asset recovery agency (AVAB) on May 1, 2004, revenues and expenditures of the consolidated general government are by lei 630 billion higher than in the budget approved by parliament on December 3, 2003, as the latter did not comprise AVAB revenues and expenditures. 
Table 4. Romania: Monetary Survey, 2002-04

(In billions of lei, actual/program exchange rates)

\begin{tabular}{|c|c|c|c|c|c|c|c|c|c|}
\hline & \multirow{2}{*}{$\begin{array}{c}2002 \\
\begin{array}{c}\text { December } \\
\text { actual }\end{array} \\
\end{array}$} & \multicolumn{4}{|c|}{2003} & \multicolumn{4}{|c|}{2004} \\
\hline & & $\begin{array}{l}\text { March } \\
\text { actual }\end{array}$ & $\begin{array}{c}\text { June } \\
\text { actual }\end{array}$ & $\begin{array}{c}\text { September } \\
\text { actual }\end{array}$ & $\begin{array}{c}\text { December } \\
\text { actual }\end{array}$ & $\begin{array}{l}\text { March } \\
\text { actual }\end{array}$ & $\begin{array}{c}\text { June } \\
\text { program }\end{array}$ & $\begin{array}{c}\text { September } \\
\text { program }\end{array}$ & $\begin{array}{l}\text { December } \\
\text { program }\end{array}$ \\
\hline \multicolumn{10}{|l|}{ Monetary Survey } \\
\hline Net foreign assets (including valuation changes) & 222,271 & 212,784 & 201,431 & 230,180 & 247,028 & 268,973 & 289,797 & 321,862 & 316,533 \\
\hline In millions of U.S. dollars & 6,635 & 6,411 & 6,101 & 6,985 & 7,579 & 8,043 & 8,624 & 9,450 & 9,172 \\
\hline Of which: Commercial banks & 87 & -216 & -246 & -668 & $-1,242$ & $-1,139$ & $-1,239$ & $-1,339$ & $-1,439$ \\
\hline NBR 4/ & 6,548 & 6,627 & 6,347 & 7,653 & 8,821 & 9,182 & 9,863 & 10,789 & 10,611 \\
\hline Net domestic assets & 151,441 & 156,667 & 187,068 & 184,289 & 213,723 & 212,488 & 213,818 & 214,137 & 269,571 \\
\hline Domestic credit & 200,221 & 215,324 & 246,397 & 242,184 & 300,943 & 324,105 & 327,693 & 339,164 & 382,916 \\
\hline Government & 21,493 & 18,505 & 22,871 & $-18,126$ & $-1,936$ & -926 & $-17,443$ & $-27,313$ & $-9,896$ \\
\hline Non-government & 178,728 & 196,819 & 223,525 & 260,310 & 302,879 & 325,031 & 345,136 & 366,477 & 392,812 \\
\hline In foreign currency & 111,999 & 119,710 & 128,407 & 146,269 & 167,839 & 181,458 & 192,339 & 205,421 & 219,371 \\
\hline (in millions of U.S. dollars) & 3,343 & 3,607 & 3,889 & 4,439 & 5,149 & 5,426 & 5,724 & 6,031 & 6,356 \\
\hline In lei & 66,729 & 77,109 & 95,118 & 114,041 & 135,040 & 143,573 & 152,796 & 161,056 & 173,441 \\
\hline Other items net & $-48,780$ & $-58,657$ & $-59,328$ & $-57,895$ & $-87,220$ & $-111,617$ & $-113,874$ & $-125,027$ & $-113,345$ \\
\hline Broad money & 373,712 & 369,451 & 388,499 & 414,468 & 460,751 & 481,460 & 503,615 & 535,999 & 586,105 \\
\hline Of which: Lei denominated (M2) & 226,901 & 223,134 & 235,809 & 254,848 & 289,583 & 293,250 & 306,087 & 327,277 & 364,252 \\
\hline Currency in circulation & 45,578 & 45,868 & 52,535 & 58,143 & 57,978 & 57,773 & 63,478 & 68,679 & 70,579 \\
\hline Lei deposits & 181,322 & 177,267 & 183,274 & 196,706 & 231,604 & 235,477 & 242,609 & 258,598 & 293,672 \\
\hline Foreign currency deposits & 146,812 & 146,317 & 152,691 & 159,620 & 171,169 & 188,211 & 197,528 & 208,722 & 221,853 \\
\hline In millions of U.S. dollars & 4,382 & 4,409 & 4,625 & 4,844 & 5,251 & 5,628 & 5,878 & 6,128 & 6,428 \\
\hline \multicolumn{10}{|l|}{ Memorandum items: 1 / } \\
\hline Broad money (M2X) growth & 38.2 & 34.2 & 29.1 & 30.6 & 23.3 & 30.3 & 29.6 & 29.3 & 27.2 \\
\hline NFA contribution $1 /$ & 18.6 & 12.5 & 1.3 & 6.6 & -5.3 & 2.5 & 11.0 & 10.6 & 15.1 \\
\hline NDA contribution 1/ & 19.5 & 21.7 & 27.8 & 24.0 & 28.6 & 27.8 & 18.1 & 18.8 & 12.1 \\
\hline Lei-denominated money growth (M2) & 46.6 & 41.5 & 33.7 & 34.5 & 27.6 & 31.4 & 29.8 & 28.4 & 25.8 \\
\hline Growth of currency in circulation & 27.9 & 37.3 & 32.6 & 37.3 & 27.2 & 26.0 & 20.8 & 18.1 & 21.7 \\
\hline Real broad money growth & 17.2 & 14.6 & 13.2 & 12.7 & 8.1 & 15.3 & 15.2 & 16.7 & 16.7 \\
\hline Real lei-denominated money growth (M2) & 24.4 & 20.8 & 17.3 & 16.1 & 11.9 & 16.2 & 15.4 & 15.8 & 15.4 \\
\hline Real growth of currency in circulation & 8.5 & 17.2 & 16.3 & 18.6 & 11.5 & 11.4 & 7.4 & 6.6 & 11.7 \\
\hline Growth of lei credit to nongovernment, adjusted 2/ & 40.4 & 49.4 & 76.5 & 92.9 & 99.3 & 83.5 & 61.7 & 41.8 & 28.7 \\
\hline Growth of lei credit to nongovernment, adjusted, real $2 /$ & 19.1 & 27.6 & 54.8 & 66.5 & 74.7 & 62.3 & 43.7 & 27.9 & 18.1 \\
\hline Growth of foreign currency credit, adjusted, in US\$ $2 /$ & 40.4 & 37.8 & 29.1 & 36.1 & 38.2 & 39.6 & 39.8 & 31.2 & 24.9 \\
\hline Growth of credit to nongovernment, composite $2 / 3 /$ & 32.4 & 33.7 & 40.3 & 49.9 & 55.4 & 50.2 & 41.6 & 29.6 & 21.7 \\
\hline CPI inflation (in percent) & 17.8 & 17.1 & 14.0 & 15.8 & 14.1 & 13.1 & 12.5 & 10.9 & 9.0 \\
\hline M2X (Broad Money) velocity & 4.3 & 4.9 & 4.8 & 4.7 & 4.4 & 4.5 & 4.4 & 4.2 & 4.0 \\
\hline M2 (Domestic Broad Money) velocity & 7.1 & 8.2 & 7.9 & 7.6 & 7.0 & 7.5 & 7.3 & 7.0 & 6.4 \\
\hline $\mathrm{M} 2 \mathrm{X}+\mathrm{Tbill}$ velocity & 3.9 & 4.4 & 4.3 & 4.2 & 4.0 & 4.1 & 4.0 & 3.8 & 3.6 \\
\hline $\mathrm{M} 2 \mathrm{X}+\mathrm{Tbill}$ growth & 38.0 & 32.8 & 25.9 & 27.2 & 21.6 & 28.8 & 29.6 & 29.2 & 27.0 \\
\hline
\end{tabular}

Sources: Romanian authorities; and Fund staff estimates.

1/ All changes are 12-month rates of change, unless indicated otherwise. The NFA/NDA contribution rates are adjusted for the change in the euro/US\$ exchange rate from December 2003.

2/ Adjusted for write-offs in the last 12 months and changes in the US\$/euro exchange rate.

3/ Real lei credit growth and foreign currency credit growth, weighted by their respective shares.

4/ Numbers before and after December 2003 are not strictly comparable, owing to an update in the US\$/euro exchange rate used to convert euro stocks in US\$-equivalent. 
Table 4. (continued) Romania: Monetary Survey, 2002-04 1/

(In billions of lei, actual/program exchange rates, monthly averages)

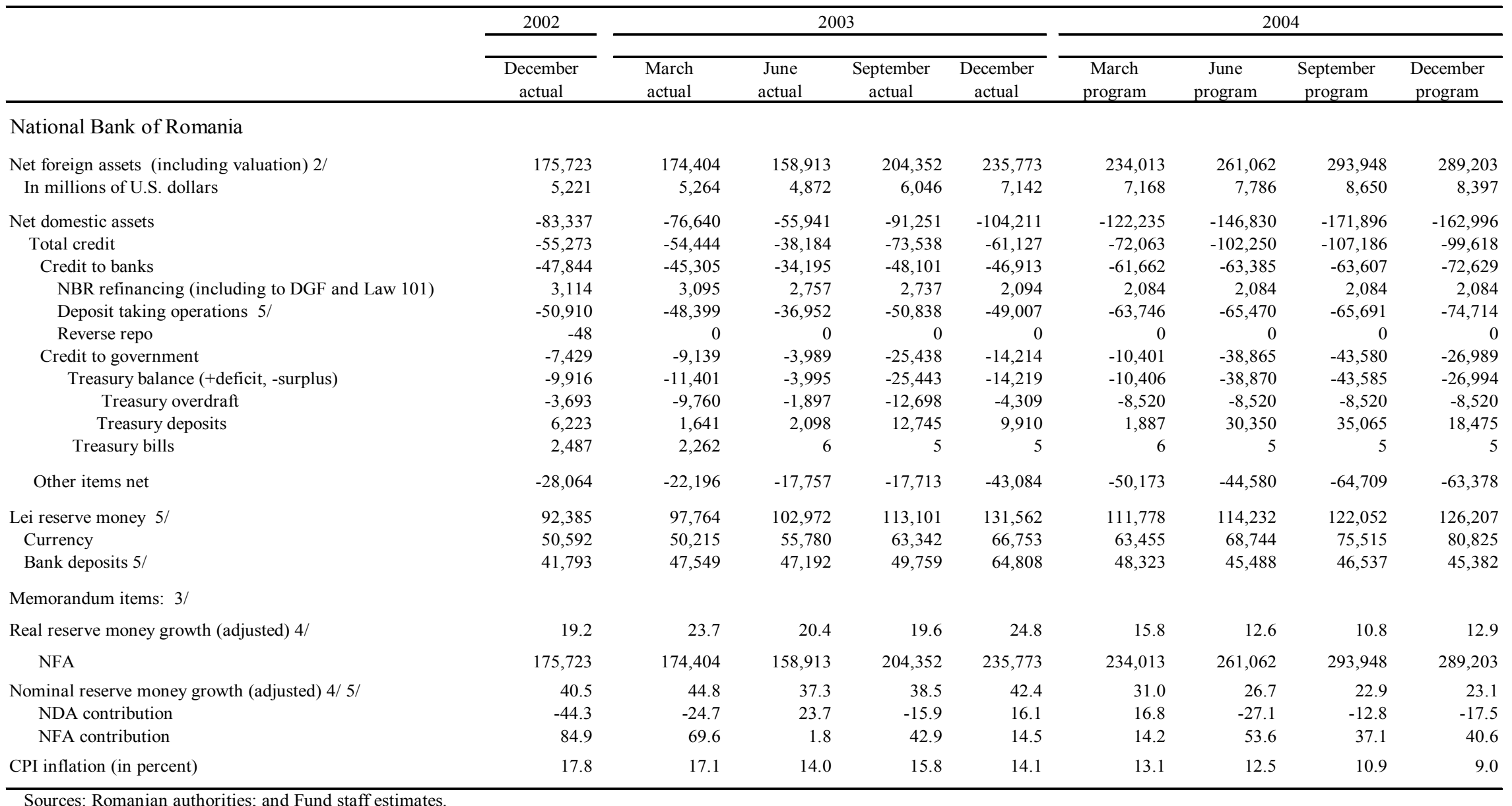

1/ For program purposes, all values are defined on a monthly average basis.

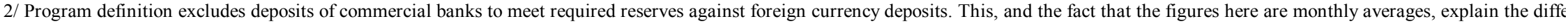

3/ All changes are 12-month rates of change, unless indicated otherwise.

4/ Adjusted for changes in minimum reserve requirements.

The minimum reserve requirement for lei deposits was decreased in 2002 from 25 percent to 22 percent in April and further to 18 percent in December.

5/ Adjusted to correspond to a 25 percent reserve requirement until end-2003 and 18 percent afterwards. 
Table 5. Implicit Subsidies and Losses in the Energy Sector

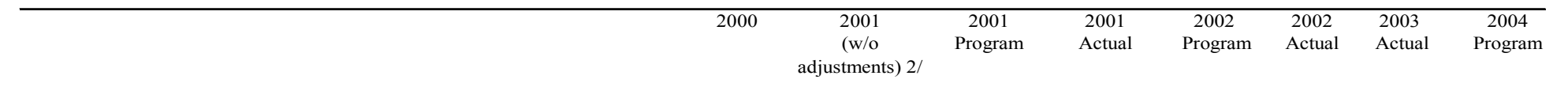

\section{HEATING}

Cost recovery price $(\$ /$ Gcal) 1

Current prices (\$/Gcal, year-average)

Termoelectrica's heating output sold (million Gcal)

Termoelectrica's losses from heating $(\$ \mathrm{~m})$

Losses from non-collection (\$m)

\section{ELECTRICITY}

rice (\$/Mwh) $1 /$

Actual prices ( $\$$ Mwh, year-average)

Termoelectrica's electricity output sold (million Mwh)

Termoelectrica's losses from electricity $(\$ \mathrm{~m})$

Collection rate $(\%)$

Losses from non-collection $(\$ \mathrm{~m})$

Total losses from operations $(\$ \mathrm{~m})$

In percent of GDP

(

In percent of GDP

In percent of GDP

NATURAL GAS PRODUCTION

Import price (average $\$ /$ tcm

Domestic wellhead price (average, incl. excise tax, $\$ / \mathrm{tcm}$ )

Domestic output (million tem)

Loss from low prices $(\$ \mathrm{~m})$

Total supply to end-users, incl. transp. \& dist. (\$m)

Losses from non-collection (\$m)

Total losses and implicit subsidy $(\$ \mathrm{~m})$

In percent of GDP

TOTAL IMPLICIT SUBSIDIES AND LOSSES (\$m)

In percent of GDP

Estimated change in saving - investment balance of public enterprises 3/

Memorandum item:
GDP (in USD Mill.)

\section{Losses at Termoelectrica and the externalized units}

$\begin{array}{cccccccc}19.2 & 20.0 & 20.0 & 20.2 & 20.0 & 20.2 & 22.9 & 24.5 \\ 11.2 & 10.4 & 12.0 & 12.3 & 17.0 & 16.6 & 21.0 & 22.9 \\ 22 & 26 & 26 & 23 & 26 & 23 & 23.4 & 23.4 \\ 181 & 249 & 198 & 180 & 77 & 84 & 45 & 36 \\ & & & 86 & 86 & 81 & 83 & 90 \\ & & & 41 & 62 & 75 & 82 & 54 \\ & & & & & & & \\ 35.4 & 40.0 & 40.0 & 38.1 & 40.0 & 38.4 & 44.1 & 45.4 \\ 34.2 & 28.5 & 32.0 & 32.2 & 38.0 & 36.3 & 40.8 & 42.3 \\ 26 & 29 & 29 & 28 & 29 & 28 & 27.9 & 28 \\ 30 & 329 & 234 & 165 & 47 & 58 & 92 & 88 \\ & & & 86 & 93 & 94 & 90 & 98 \\ & & & 131 & 83 & 57 & 119 & 24 \\ 210 & 578 & 432 & 346 & 124 & 142 & 137 & 124 \\ 0.6 & 1.5 & 1.1 & 0.9 & 0.3 & 0.3 & 0.2 & 0.2 \\ 208 & 270 & 61 & 171 & 145 & 132 & 200 & 77 \\ 418 & 848 & 493 & 517 & 269 & 273 & 337 & 201 \\ 1.1 & 2.1 & 1.2 & 1.3 & 0.6 & 0.6 & 0.6 & 0.3\end{array}$

\section{Implicit Subsidies from Natural Gas}

\begin{tabular}{|c|c|c|c|c|c|c|c|}
\hline 124 & 130 & 130 & 130 & 120 & 110 & 137 & 141.5 \\
\hline 35 & 26 & 35 & 35 & 46 & 40 & 35.6 & 67.1 \\
\hline 14.0 & 14.0 & 14.0 & 13.0 & 14.0 & 12.1 & 12.7 & 12.5 \\
\hline 1246 & 1456 & 1327 & 1230 & 1025 & 842 & 1286 & 930 \\
\hline 566 & 1103 & 1103 & 974 & 1155 & 981 & 1248 & 1569 \\
\hline 87 & 76 & 95 & 86 & 90 & 99 & 99 & 98 \\
\hline 74 & 270 & 55 & 141 & 29 & 12 & 16 & 27 \\
\hline 1320 & 1726 & 1382 & 1371 & 1054 & 854 & 1302 & 958 \\
\hline 3.6 & 4.3 & 3.5 & 3.4 & 2.3 & 1.9 & 2.3 & 1.4 \\
\hline 1738 & 2574 & 1875 & 1888 & 1323 & 1127 & 1639 & 1159 \\
\hline 4.7 & 6.5 & 4.7 & 4.7 & 2.9 & 2.46 & 2.88 & 1.73 \\
\hline & 1.8 & 0.0 & 0.0 & -1.8 & -2.24 & 0.42 & -1.15 \\
\hline$\ldots$ & -0.6 & 0.0 & 0.0 & 0.6 & 0.75 & -0.21 & 0.57 \\
\hline 37,060 & 39,721 & 39,721 & 40,172 & 45,135 & 45,760 & 56,950 & 66,994 \\
\hline
\end{tabular}

Sources: ANRE (electricity regulatory agency), Termoelectrica and Distrigaz Nord and Sud; World Bank; Fund staff estimates.

$1 /$ Cost recovery price estimates based on WEO fuel price projections.

/ Estimates, as of September 2001, based on the assumption that the adjustments as envisaged under the program were not implemented.

i) increase in losses in other public enterprises,

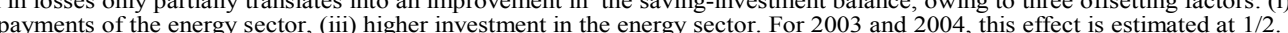


Table 6. Romania: Medium-Term Balance of Payments Outlook, 2000-08

(In millions of U.S. dollars)

\begin{tabular}{|c|c|c|c|c|c|c|c|c|c|}
\hline & $\begin{array}{r}2000 \\
\text { Act. }\end{array}$ & $\begin{array}{r}2001 \\
\text { Act. }\end{array}$ & $\begin{array}{r}2002 \\
\text { Act. }\end{array}$ & $\begin{array}{l}2003 \\
\text { Proj. }\end{array}$ & $\begin{array}{l}2004 \\
\text { Proj. }\end{array}$ & $\begin{array}{l}2005 \\
\text { Proj. }\end{array}$ & $\begin{array}{l}2006 \\
\text { Proj. }\end{array}$ & $\begin{array}{l}2007 \\
\text { Proj. }\end{array}$ & $\begin{array}{l}2008 \\
\text { Proj. }\end{array}$ \\
\hline Current account & $-1,435$ & $-2,223$ & $-1,572$ & $-3,367$ & $-3,483$ & $-3,862$ & $-4,141$ & $-4,544$ & $-4,955$ \\
\hline Ratio to GDP & -3.9 & -5.5 & -3.4 & -5.9 & -5.2 & -5.3 & -5.2 & -5.2 & -5.2 \\
\hline Trade balance & $-1,684$ & $-2,969$ & $-2,612$ & $-4,537$ & $-4,680$ & $-4,980$ & $-5,249$ & $-5,552$ & $-5,855$ \\
\hline Exports & 10,366 & 11,385 & 13,870 & 17,618 & 20,959 & 22,719 & 24,642 & 26,696 & 28,963 \\
\hline Imports & $-12,050$ & $-14,354$ & $-16,482$ & $-22,155$ & $-25,639$ & $-27,699$ & $-29,891$ & $-32,248$ & $-34,818$ \\
\hline Services account, net & -254 & -397 & -496 & -683 & -956 & $-1,221$ & $-1,394$ & $-1,593$ & $-1,826$ \\
\hline Of which: interest, net & -382 & -288 & -413 & -575 & -694 & -864 & -941 & $-1,033$ & $-1,142$ \\
\hline Unrequited transfers & 860 & 1,143 & 1,536 & 1,854 & 2,153 & 2,339 & 2,503 & 2,601 & 2,726 \\
\hline Capital account & 2,738 & 3,140 & 3,342 & 3,273 & 4,611 & 4,210 & 4,624 & 5,307 & 5,838 \\
\hline Direct investment & 1,051 & 1,175 & 1,090 & 1,485 & 2,174 & 2,540 & 2,385 & 2,385 & 2,373 \\
\hline Capital transfers & 36 & 95 & 88 & 206 & 219 & 244 & 255 & 350 & 400 \\
\hline Portfolio Investment & 50 & 71 & 129 & -11 & 50 & 50 & 50 & 50 & 50 \\
\hline Borrowing by public sector 1 / & 882 & 1,087 & 931 & 1,191 & 2,004 & 924 & 1,155 & 1,484 & 1,824 \\
\hline Loans (net) & 805 & 314 & 668 & 571 & 1,442 & 517 & 405 & 734 & 1,759 \\
\hline Disbursements & 1,544 & 1,337 & 1,926 & 1,798 & 2,854 & 2,467 & 2,805 & 3,156 & 3,525 \\
\hline Of which: direct debt & 959 & 465 & 732 & 535 & 944 & 1,013 & 1,213 & 1,413 & 1,613 \\
\hline Of which: government guaranteed & 584 & 873 & 1,194 & 1,263 & 1,910 & 1,454 & 1,592 & 1,743 & 1,912 \\
\hline Amortization & -739 & $-1,023$ & $-1,259$ & $-1,227$ & $-1,412$ & $-1,950$ & $-2,400$ & $-2,422$ & $-1,766$ \\
\hline Bonds (net) & 77 & 773 & 263 & 620 & 562 & 407 & 750 & 750 & 65 \\
\hline Disbursements & 259 & 922 & 723 & 811 & 757 & 750 & 750 & 750 & 750 \\
\hline Amortization & -182 & -149 & -460 & -191 & -195 & -343 & 0 & 0 & -685 \\
\hline Borrowing by private sector & 748 & 565 & 624 & 111 & 164 & 452 & 780 & 1,038 & 1,192 \\
\hline Medium- and long-term loans (net) & 748 & 565 & 624 & 111 & 164 & 452 & 780 & 1,038 & 1,192 \\
\hline Disbursements & 1,059 & 1,090 & 1,333 & 1,179 & 1,620 & 2,026 & 2,532 & 3,038 & 3,494 \\
\hline Amortization & -311 & -525 & -710 & $-1,068$ & $-1,456$ & $-1,573$ & $-1,752$ & $-2,000$ & $-2,302$ \\
\hline Short-term (net) & 5 & 193 & 458 & 321 & 0 & 0 & 0 & 0 & 0 \\
\hline Credit extended & -34 & -45 & 23 & -29 & 0 & 0 & 0 & 0 & 0 \\
\hline Net errors and ommisions & 340 & 992 & -574 & -334 & 461 & 0 & 0 & 0 & 0 \\
\hline Overall balance & 1,643 & 1,909 & 1,196 & -427 & 1,589 & 348 & 482 & 763 & 883 \\
\hline Financing & $-1,643$ & $-1,909$ & $-1,196$ & 427 & $-1,590$ & -348 & -482 & -763 & -883 \\
\hline Net foreign assets NBR (increase, -) & $-1,170$ & $-1,949$ & $-1,975$ & -902 & $-1,789$ & -728 & -862 & $-1,143$ & $-1,263$ \\
\hline Assets (increase, -) & $-1,004$ & $-1,624$ & $-1,885$ & $-1,019$ & $-1,670$ & -658 & -753 & -990 & $-1,170$ \\
\hline Liabilities & -166 & -325 & -90 & 117 & -119 & -70 & -110 & -153 & -92 \\
\hline IMF, net & 20 & -50 & 10 & 117 & -119 & -70 & -110 & -153 & -92 \\
\hline Purchases & 115 & 67 & 107 & 226 & 0 & 0 & 0 & 0 & 0 \\
\hline Repurchases & -95 & -117 & -98 & -109 & -119 & -70 & -110 & -153 & -92 \\
\hline Other, net & -186 & -275 & -100 & 0 & 0 & 0 & 0 & 0 & 0 \\
\hline Short-term & -14 & 0 & -100 & 0 & 0 & 0 & 0 & 0 & 0 \\
\hline Medium- and long-term, net & -172 & -275 & 0 & 0 & 0 & 0 & 0 & 0 & 0 \\
\hline Net foreign assets DMBs (increase, -) & -473 & 40 & 779 & 1,329 & 199 & 380 & 380 & 380 & 380 \\
\hline Assets (increase, -) & -336 & -99 & 433 & 127 & -194 & -20 & -20 & -20 & -20 \\
\hline Liabilities & -137 & 139 & 346 & 1,202 & 393 & 400 & 400 & 400 & 400 \\
\hline Short-term & 4 & 146 & 120 & 0 & 0 & 0 & 0 & 0 & 0 \\
\hline Medium- and long-term, net & -111 & -5 & 226 & 0 & 0 & 0 & 0 & 0 & 0 \\
\hline Financing gap & 0 & 0 & 0 & 0 & 0 & 0 & 0 & 0 & 0 \\
\hline Export growth (percent) & 21.9 & 9.8 & 21.8 & 27.0 & 19.0 & 8.4 & 8.5 & 8.3 & 8.5 \\
\hline Import growth (percent) & 23.7 & 19.1 & 14.8 & 34.4 & 15.7 & 8.0 & 7.9 & 7.9 & 8.0 \\
\hline Net Resource Balance/GDP (percent) & -2.9 & -4.8 & -2.4 & -4.7 & -3.9 & -3.9 & -3.8 & -3.8 & -3.8 \\
\hline External debt/GDP (percent) & 28.7 & 30.7 & 34.3 & 34.6 & 33.2 & 33.1 & 33.1 & 33.3 & 33.7 \\
\hline Public and publicly guaranteed debt/GDP (percent) & 18.8 & 19.4 & 21.1 & 21.6 & 20.8 & 20.4 & 19.9 & 19.7 & 19.8 \\
\hline Net External Indebtedness/GDP (\%) & 15.3 & 14.0 & 16.6 & 18.7 & 17.0 & 17.1 & 17.6 & 18.0 & 18.4 \\
\hline Debt service ratio & 16.9 & 20.2 & 20.1 & 16.4 & 17.0 & 19.4 & 19.5 & 19.4 & 19.2 \\
\hline Gross reserves of NBR (in millions of US\$) $2 /$ & 3,466 & 5,090 & 6,975 & 7,994 & 9,664 & 10,323 & 11,075 & 12,065 & 13,236 \\
\hline (over short-term debt by remaining maturity) & 148.9 & 160.3 & 204.2 & 157.6 & 188.1 & 186.4 & 186.6 & 191.6 & .. \\
\hline (in months of imports of following year) & 2.5 & 3.2 & 3.3 & 3.3 & 3.7 & 3.7 & 3.7 & 3.7 & .. \\
\hline
\end{tabular}

Sources: Romanian authorities; and Fund staff estimates.

1/ Including public enterprises.

2/ Includes gold. 
Table 7. Romania: External Financing Requirements and Sources, 1999-2008 (In millions of U.S. dollars)

\begin{tabular}{|c|c|c|c|c|c|c|c|c|c|c|}
\hline & 1999 & 2000 & 2001 & 2002 & 2003 & 2004 & 2005 & 2006 & 2007 & 2008 \\
\hline & & & & & & \multicolumn{5}{|c|}{ Proj. } \\
\hline Gross financing requirements & 3,742 & 4,388 & 6,135 & 5,650 & 6,854 & 8,530 & $\mathbf{8 , 4 7 7}$ & 9,176 & 10,129 & 10,991 \\
\hline External current account deficit & 1,446 & 1,435 & 2,223 & 1,572 & 3,367 & 3,483 & 3,862 & 4,141 & 4,544 & 4,955 \\
\hline Debt amortization & 2,244 & 1,518 & 2,072 & 2,528 & 2,486 & 3,064 & 3,866 & 4,152 & 4,422 & 4,753 \\
\hline Public sector & 1,610 & 1,207 & 1,547 & 1,819 & 1,418 & 1,607 & 2,293 & 2,400 & 2,422 & 2,451 \\
\hline of which: Bonds and notes & 747 & 354 & 424 & 460 & 191 & 195 & 343 & 0 & 0 & 685 \\
\hline Private sector & 634 & 311 & 525 & 710 & 1,068 & 1,456 & 1,573 & 1,752 & 2,000 & 2,302 \\
\hline Repayment of arrears & 0 & 0 & 0 & 0 & 0 & 0 & 0 & 0 & 0 & 0 \\
\hline Gross reserves accumulation & -87 & 1,340 & 1,723 & 1,452 & 892 & 1,864 & 678 & 773 & 1,010 & 1,190 \\
\hline IMF repurchases and repayments & 139 & 95 & 117 & 98 & 109 & 119 & 70 & 110 & 153 & 92 \\
\hline Available financing & 3,203 & 3,828 & 5,968 & 5,375 & 6,572 & 8,243 & $\mathbf{8 , 4 7 7}$ & 9,176 & 10,129 & 10,991 \\
\hline FDI and capital transfers (net) & 1,070 & 1,087 & 1,270 & 1,178 & 1,691 & 2,393 & 2,784 & 2,639 & 2,735 & 2,773 \\
\hline Public sector borrowing & 815 & 1,458 & 2,259 & 2,481 & 2,554 & 3,325 & 3,217 & 3,555 & 3,906 & 4,275 \\
\hline Loans & 815 & 1,199 & 1,337 & 1,758 & 1,742 & 2,568 & 2,467 & 2,805 & 3,156 & 3,525 \\
\hline Bonds & 0 & 259 & 922 & 723 & 811 & 757 & 750 & 750 & 750 & 750 \\
\hline Private sector borrowing & 780 & 922 & 1,229 & 1,679 & 2,381 & 2,013 & 2,426 & 2,932 & 3,438 & 3,894 \\
\hline Other flows $1 /$ & 538 & 361 & 1,210 & 36 & -53 & 511 & 50 & 50 & 50 & 50 \\
\hline Financing gap & 539 & 560 & 167 & 275 & 281 & 287 & 0 & 0 & 0 & 0 \\
\hline Balance of payments financing & 539 & 560 & 167 & 275 & 281 & 286 & 0 & 0 & 0 & 0 \\
\hline IMF & 73 & 115 & 67 & 107 & 226 & 0 & 0 & 0 & 0 & 0 \\
\hline Other $2 /$ & 466 & 445 & 100 & 168 & 56 & 286 & 0 & 0 & 0 & 0 \\
\hline Accumulation of arrears (exceptional) & 0 & 0 & 0 & 0 & 0 & 0 & 0 & 0 & 0 & 0 \\
\hline Residual financing gap & 0 & 0 & 0 & 0 & 0 & 1 & 0 & 0 & 0 & 0 \\
\hline
\end{tabular}

Sources: Romanian authorities; and Fund staff estimates.

1/ Includes all other net financial flows, and errors and omissions.

2/ Includes World Bank PSAL2 and EU loans. 
Table 8. Romania: Indicators of External Vulnerability, 1998-2004 1/

(In percent of GDP unless otherwise specified)

\begin{tabular}{|c|c|c|c|c|c|c|c|}
\hline & 1998 & 1999 & 2000 & 2001 & 2002 & 2003 & $\begin{array}{c}2004 \\
\text { proj. }\end{array}$ \\
\hline \multicolumn{8}{|l|}{ Financial Indicators } \\
\hline Public sector debt & 27.6 & 30.5 & 29.9 & 27.4 & 26.8 & 26.2 & 26.7 \\
\hline Broad money (percent change, 12-month basis) & 48.9 & 44.9 & 38.0 & 46.2 & 38.1 & 23.3 & 27.2 \\
\hline Credit to non-government (percent change, 12 -month basis) 2/ & 64.7 & 45.8 & 50.5 & 59.9 & 46.3 & 77.3 & 32.3 \\
\hline Real credit to non-government (percent change, 12 -month basis) $2 /$ & 17.0 & -9.2 & 7.4 & 26.0 & 29.6 & 55.4 & 21.4 \\
\hline Monthly weighted average T-bill rate & 82.4 & 105.2 & 62.4 & 38.4 & 17.4 & 18.4 & $20.8 \quad 4 /$ \\
\hline Monthly weighted average real T-bill rate 3 / & 29.7 & 32.6 & 15.4 & 6.3 & -0.3 & 3.7 & $7.44 /$ \\
\hline \multicolumn{8}{|l|}{ External Indicators } \\
\hline Exports (percent change, 12-month basis in US\$) & -1.6 & 2.4 & 21.9 & 9.8 & 21.8 & 27.0 & 19.0 \\
\hline Imports (percent change, 12-month basis in US\$) & 4.8 & -12.1 & 23.7 & 19.1 & 14.8 & 34.4 & 15.7 \\
\hline Terms of Trade (percent change, 12-month basis) & -4.0 & 0.2 & 2.7 & 2.3 & 1.5 & 0.2 & 1.6 \\
\hline Current account balance & -6.9 & -4.0 & -3.9 & -5.5 & -3.4 & -5.9 & -5.2 \\
\hline Current account balance after FDI & -2.0 & -1.2 & -0.9 & -2.4 & -0.9 & -2.9 & -1.6 \\
\hline Errors and omissions & 0.8 & 2.3 & 0.9 & 2.5 & -1.2 & -0.6 & 0.7 \\
\hline Gross official reserves (in US\$ millions) & 2,278 & 2,462 & 3,466 & 5,090 & 6,975 & 7,994 & 9,664 \\
\hline (in months of imports GNFS of the following year) & 2.4 & 2.1 & 2.5 & 3.2 & 3.3 & 3.3 & 3.7 \\
\hline Central Bank short-term foreign liabilities (in US\$ millions) & 0 & 170 & 100 & 100 & 0 & 0 & 0 \\
\hline Gross reserves of the banking system (in US\$ millions) & 3,768 & 3,623 & 4,963 & 6,686 & 8,138 & 9,030 & 10,894 \\
\hline (in months of imports GNFS of the following year) & 3.9 & 3.1 & 3.6 & 4.3 & 3.9 & 3.7 & 4.2 \\
\hline Short term foreign liabilities of the commercial banks (in US\$) & 188 & 221 & 225 & 371 & 491 & 1,208 & $1,2645 /$ \\
\hline Open foreign currency position of the commercial banks (in US\$) & 1,933 & 724 & 318 & 355 & 380 & 403 & $5395 / 10 /$ \\
\hline Official reserves/Broad money (M2) & 27.0 & 33.5 & 48.6 & 59.5 & 62.5 & 55.8 & 56.9 \\
\hline Official reserves/Narrow money (M0) 6/ & 106.1 & 143.6 & 187.5 & 241.7 & 302.3 & 215.7 & 229.4 \\
\hline Total short term external debt by remaining maturity $7 /$ & 6.4 & 5.1 & 6.3 & 7.9 & 7.4 & 8.9 & 7.7 \\
\hline In percent of reserves & 119.1 & 74.2 & 67.2 & 62.4 & 49.0 & 63.4 & 53.2 \\
\hline In percent of total debt & 29.9 & 23.2 & 21.9 & 25.8 & 21.7 & 25.8 & 23.1 \\
\hline Total external debt (in US\$ millions) & 9,899 & 9,156 & 10,649 & 12,325 & 15,745 & 19,693 & 22,256 \\
\hline Of which: Public and Publicly guaranteed debt & 6,967 & 6,219 & 6,957 & 7,736 & 9,572 & 12,071 & 13,956 \\
\hline Total external debt (in percent of exports of G\&S) & 104.0 & 92.8 & 87.8 & 91.9 & 97.2 & 95.5 & 92.2 \\
\hline Total external debt/ GDP & 23.5 & 25.6 & 28.7 & 30.7 & 34.3 & 34.6 & 33.2 \\
\hline External interest payments (in percent of exports of G\&S) & 5.7 & 5.1 & 4.4 & 4.6 & 3.9 & 3.8 & 3.9 \\
\hline External amortization payments (in percent of exports of G\&S) & 18.0 & 23.9 & 12.5 & 15.6 & 16.2 & 12.6 & 13.2 \\
\hline Exchange rate (per US\$, period average) & 8,881 & 15,274 & 21,688 & 29,056 & 33,055 & 33,201 & $\ldots$ \\
\hline REER appreciation $(+)$ (12-month basis) & 30.0 & -14.8 & 9.5 & 1.6 & 2.7 & $\ldots$ & $\ldots$ \\
\hline \multicolumn{8}{|l|}{ Financial Market Indicators } \\
\hline \multicolumn{8}{|l|}{ Foreign currency debt ratings } \\
\hline Moody's & B3 & B3 & B3 & B2 & B1 & B1 & $\mathrm{Ba} 38 /$ \\
\hline Standard and Poor's & B- & B- & B- & $\mathrm{B}$ & $\mathrm{B}+$ & $\mathrm{BB}+$ & BB 8/ \\
\hline Spread of benchmark bonds (basis points, end of period) & 1,300 & 780 & 406 & 400 & 282 & 161 & $1868 / 9 /$ \\
\hline
\end{tabular}

Sources: Romanian authorities; and Fund staff estimates.

1/ All stocks are reported as of end of period.

2/ Adjusted for bad loans written off. Real credit growth is weighted average of real lei credit growth, and U.S. dollar-measured foreign currency growth.

3/ The real rate is based on the ex-post 12-month CPI inflation.

4/ Actual as of April 2004.

5/ Actual as of March 2004.

6/ Narrow money is defined as currency plus lei-denominated sight deposits.

7/ Defined as short-term debt by original maturity basis plus amortization falling due on medium-term loans and bonds.

8/ For 2004, entries as of June 9, 2004.

9/ In 1998-2000, the benchmark bond is the ' 02 ; in 2001-2003, it is the '05; in 2004, it is the ' 08.

10/ On-balance-sheet only. The overall open currency position, including off-balance-sheet items and capital paid in foreign exchange, was US\$40 million as of end-2003. 
Table 9. Romania: Indicators of Fund Credit, 2000-08

(In percent, unless otherwise indicated)

\begin{tabular}{|c|c|c|c|c|c|c|c|c|c|}
\hline & 2000 & 2001 & 2002 & 2003 & 2004 & 2005 & 2006 & 2007 & 2008 \\
\hline & \multicolumn{4}{|c|}{ Actual } & \multicolumn{5}{|c|}{ Projections } \\
\hline \multicolumn{10}{|l|}{$\begin{array}{l}\text { Outstanding Fund Credit } \\
\text { (end of period) }\end{array}$} \\
\hline In millions of SDRs & 347.9 & 308.0 & 314.9 & 400.4 & 339.0 & 287.4 & 206.3 & 92.7 & 23.8 \\
\hline In millions of U.S. dollars & 458.8 & 392.1 & 407.8 & 546.9 & 460.7 & 389.5 & 278.8 & 124.7 & 31.9 \\
\hline In percent of quota & 33.8 & 29.9 & 30.6 & 38.9 & 32.9 & 27.9 & 20.0 & 9.0 & 2.3 \\
\hline In percent of GDP & 1.2 & 1.0 & 0.9 & 1.0 & 0.7 & 0.5 & 0.4 & 0.1 & 0.0 \\
\hline In percent of exports of goods and services & 3.8 & 2.9 & 2.5 & 2.7 & 1.9 & 1.5 & 1.0 & 0.4 & 0.1 \\
\hline In percent of official reserves & 13.2 & 7.7 & 5.8 & 6.8 & 4.8 & 3.8 & 2.5 & 1.0 & 0.2 \\
\hline $\begin{array}{l}\text { Debt service due to the Fund } \\
\text { (in millions of U.S. dollars) }\end{array}$ & 120.3 & 117.0 & 111.3 & 123.4 & 92.8 & 80.5 & 118.4 & 158.7 & 95.1 \\
\hline In percent of quota & 8.9 & 8.9 & 8.3 & 8.8 & 6.6 & 5.8 & 8.5 & 11.4 & 6.9 \\
\hline In percent of GDP & 0.3 & 0.3 & 0.2 & 0.2 & 0.1 & 0.1 & 0.1 & 0.2 & 0.1 \\
\hline In percent of exports of goods and services & 1.0 & 0.9 & 0.7 & 0.6 & 0.4 & 0.3 & 0.4 & 0.5 & 0.3 \\
\hline In percent of official reserves & 3.5 & 2.3 & 1.6 & 1.5 & 1.0 & 0.8 & 1.1 & 1.3 & 0.7 \\
\hline
\end{tabular}

Sources: Finance Department, Romanian authorities. 
Table 10. Romania: Medium-Term Projections, 2000-08

(In percent of GDP unless otherwise specified)

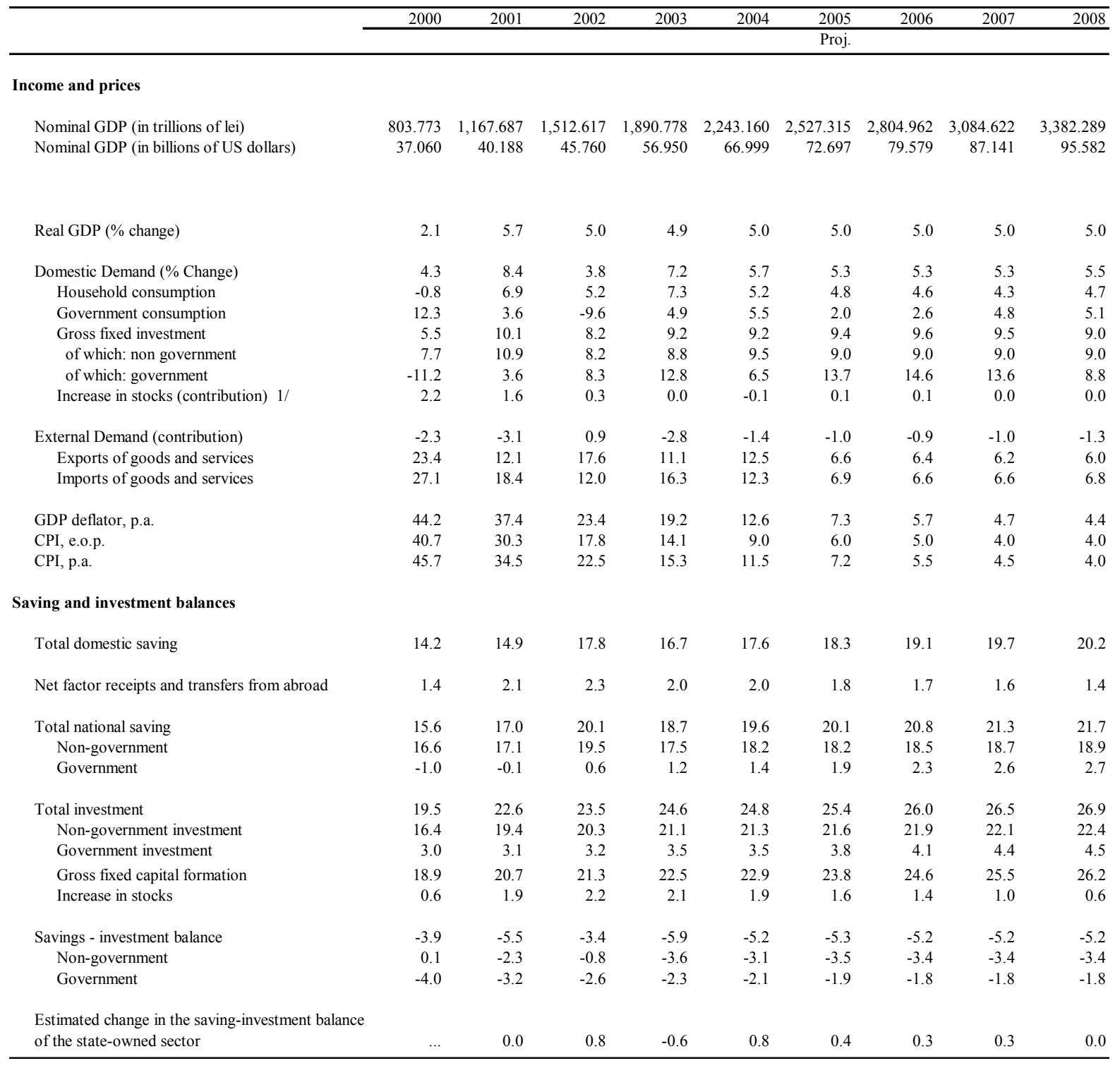

Sources: Romanian authorities; and Fund staff estimates and projections.

1/ Includes statistical discrepancy. 
Table 11. Romania: Millennium Development Goals 1/

\section{General Social Indicators}

\section{Population (millions)}

Adult literacy rate (percent of people of ages 15 and over)

23.2

97.1

1.8

69.7

Life expectancy at birth

\section{7}

97.6

1.3

69.5
22.4

98.2

1.3

69.9
22.4

1.3

70.0

\section{Goal 1. Eradicate extreme poverty and hunger}

Target: Halve between 1990 and 2015, the proportion of people who suffer from hunger.

1. Percentage share of income or consumption held by poorest $20 \%$

2. Prevalence of child malnutrition (percent of children under 5)

\section{Goal 2. Achieve universal primary education}

Target: Ensure that, by 2015, children everywhere will be able to complete a full curse of primary schooling.

3. Net primary enrollment ratio (percent of relevant age group)

\section{9}

92.0

92.8

4. Youth literacy rate ((in percent of ages 15-24)

Goal 3. Promote gender equality

Targets: Eliminate gender disparity in primary and secondary education preferably by 2005 and to all levels of education no later than 2015

5. Ratio of girls to boys in primary and secondary education (in percent)

6. Ratio of young literate females to males (percent of ages 15-24)

7. Proportion of seats held by women in national parliament (in percent)

$\begin{array}{rrrr}95.0 & 96.3 & 100.1 & \ldots \\ 99.9 & 100.0 & 100.2 & 100.2 \\ 34.0 & 7.0 & 11.0 & 11.0\end{array}$

Goal 4. Reduce child mortality

Target: Reduce by two-thirds, between 1990 and 2015, the under-five mortality rate

8. Under five mortality rate (per 1000)

9. Infant mortality rate (per 1000 live births)

10. Immunization, measles (percent of children under 12 months)

$\begin{array}{rrrrr}35.7 & 26.2 & 21.0 & 21.4 & 11.9 \\ 26.9 & 21.2 & 19.0 & 17.8 & \ldots \\ 92.0 & 93.0 & 98.0 & \ldots & \ldots\end{array}$

\section{Goal 5. Improve maternal health}

Target: Reduce by three quarters, between 1990 and 2015, the maternal mortality ratio.

11. Maternal mortality ratio (modeled estimate per 100,000 live births)

12. Births attended by skilled health staff (percent of total)

$\begin{array}{ll}\cdots & 60.0 \\ \cdots & 99.0\end{array}$




\section{Goal 6. Combat HIV/AIDS, malaria and other diseases}

Target: have halted by 2015, and begun to reverse, the spread of HIV/AIDS.

Have halted by 2015, and begun to reverse, the incidence of malaria and other major diseases.

13. Prevalence of HIV, female (percent of ages 15-24)

14. Contraceptive prevalence rate (percent of women of ages 15-49)

15. Incidence of tuberculosis (per 1,000 people)

16. Tuberculosis cases detected under DOTS (in percent)

$\begin{array}{rrr}\ldots & \ldots & 0.0 \\ \ldots & 57.3 & 48.0 \\ \ldots & \ldots & 134.9 \\ \ldots & \ldots & 9.0\end{array}$

\section{Goal 7. Ensure environmental sustainability}

Targets: Integrate the principles of sustainable development into country policies and programs and reverse the loss of environmental resources. Halve by 2015 , the proportion of people without sustainable access to safe drinking water. By 2020 , to have achieved a significant improvement in the lives of at least 100 million dwellers.

17. Forest area (percent of total land area)

18. Nationally protected areas (percent of total land area)

19. GDP per unit of energy use (PPP in US\$ per Kg. oil equivalent)

20. CO2 emissions (metric tons per capita)

21. Access to an improved water source (percent of population)

22. Access to improved sanitation (percent of population)

$\begin{array}{rrr}7.4 & \ldots & 28.0 \\ \ldots & 4.6 & 4.7 \\ 2.0 & 2.8 & 3.5 \\ 6.7 & 5.3 & 3.6 \\ \ldots & \ldots & 58.0 \\ \ldots & \ldots & 53.0\end{array}$

\section{Goal 8. Develop a Global Partnership for Development}

Targets: Develop further an open rule-based, predictable, non-discriminatory trading and financial system.

Address the special needs of the least developed countries and landlocked countries and small islands developing states.

Deal comprehensively with the debt problems of developing countries trough national and international measures in order to make debt sustainable in the long term. In cooperation with developing countries, develop and implement strategies for decent and productive work for youth. In cooperation with the private sector, make available the benefits of new technologies, specially information and communications.

23. Youth unemployment rate (percent of total labor force of ages 15-24)

24. Fixed line and mobile telephones (per 1,000 people)

25. Personal computers (per 1,000 people)

\begin{tabular}{rrrll}
$\ldots$ & 20.9 & 19.5 & $\ldots$ & $\ldots$ \\
$\ldots$ & 131.2 & 356.2 & $\ldots$ & $\ldots$ \\
2.2 & 13.2 & 35.7 & $\ldots$ & $\ldots$ \\
\hline
\end{tabular}

Source: World Development Indicators database, April 2002.

$1 /$ Includes only indicators for which data is available for any given year.

2/ Targets are indicated quantitatively wherever it is possible, but specifics are described in the goals' sections. 
Table 12. Romania: Public Sector Total Financing, 2000-04

\begin{tabular}{|c|c|c|c|c|c|c|c|c|c|c|c|c|c|}
\hline \multirow[b]{2}{*}{ lei trillion } & \multirow[t]{2}{*}{2000} & \multirow[t]{2}{*}{2001} & \multirow[t]{2}{*}{2002} & \multicolumn{5}{|c|}{2003} & \multicolumn{5}{|c|}{2004} \\
\hline & & & & Q1 & Q2 & Q3 & Q4 & Annual & Q1 & Q2 & Q3 & Q4 & Annual \\
\hline I. Consolidated General Government Financing & 34.6 & 33.1 & 41.7 & 2.5 & 4.7 & -5.5 & 21.9 & 23.6 & 6.8 & 17.0 & 4.9 & 18.4 & 47.1 \\
\hline - percent of annual GDP & 4.3 & 2.8 & 2.8 & 0.1 & 0.2 & -0.3 & 1.2 & 1.2 & 0.3 & 0.8 & 0.2 & 0.8 & 2.1 \\
\hline 1. External Financing, net & 22.6 & 25.5 & 23.6 & 3.5 & 1.5 & 31.6 & -5.2 & 31.5 & 1.1 & 31.7 & 7.9 & -1.5 & 39.2 \\
\hline - sovereign bonds and BOP support loans & 10.0 & 15.1 & 9.5 & -1.4 & -0.3 & 26.9 & -6.2 & 19.0 & -1.4 & 27.2 & 4.3 & -1.4 & 28.7 \\
\hline - project financing & 12.6 & 10.4 & 13.3 & 4.3 & 1.9 & 4.3 & 1.1 & 11.6 & 1.7 & 4.4 & 3.6 & -0.1 & 9.6 \\
\hline - leasing operations of ministries and local governme: & 0.0 & 0.0 & 0.8 & 0.7 & -0.1 & 0.1 & -0.1 & 0.4 & 0.0 & 0.0 & 0.0 & 0.0 & 0.2 \\
\hline - T-bills held by nonresidents $1 / 3 /$ & 0.0 & 0.0 & 0.0 & 0.0 & 0.0 & 0.4 & 0.0 & 0.4 & 0.8 & 0.0 & 0.0 & 0.0 & 0.8 \\
\hline 2. Non-Bank Financing & 19.4 & 19.5 & 21.2 & 6.2 & -2.3 & 2.6 & 3.4 & 10.0 & 10.3 & 2.2 & 9.8 & 2.3 & 24.6 \\
\hline - privatization receipts $7 /$ & 5.1 & 3.6 & 7.6 & 1.6 & 1.0 & 0.6 & 1.1 & 4.3 & 1.6 & 1.0 & 8.8 & 1.2 & 12.6 \\
\hline - asset recovery $8 /$ & 2.6 & 2.6 & 2.2 & 0.5 & 0.5 & 0.5 & 0.5 & 2.0 & 0.4 & 0.4 & 0.2 & 0.3 & 1.3 \\
\hline - municipal bonds held by the non-bank public & 0.0 & 0.0 & 0.1 & 0.0 & 0.0 & 0.3 & 0.1 & 0.4 & -0.2 & -0.2 & -0.2 & -0.2 & -0.9 \\
\hline - T-bills held by the non-bank public $1 / 2$ / & 11.7 & 13.3 & 11.3 & 4.1 & -3.8 & 1.3 & 1.7 & 3.3 & 8.6 & 1.0 & 1.0 & 1.0 & 11.6 \\
\hline 3. Bank Financing 1/ & -7.3 & -11.9 & -3.1 & -7.2 & 5.5 & -39.8 & 23.7 & -17.8 & -4.6 & -16.8 & -12.8 & 17.6 & -16.6 \\
\hline - T-bills and bonds in lei held by banks, incl. municip & 7.9 & -10.6 & -1.2 & 0.3 & 0.0 & -17.4 & -0.3 & -17.4 & 0.1 & & & & \\
\hline - T-bills and bonds in foreign currencies held by bank & -14.4 & 7.8 & -0.9 & -2.8 & 1.2 & 0.7 & -2.0 & -2.8 & -0.9 & & & & \\
\hline - bank loans in lei & -0.9 & 0.1 & 0.3 & -0.6 & 0.0 & 0.1 & 0.1 & -0.3 & 0.1 & & & & \\
\hline - bank loans in foreign currencies & & & & 0.3 & -0.2 & 0.4 & 1.0 & 1.4 & 0.5 & & & & \\
\hline - decrease in deposits of the Nat. Road Administration & & & & -0.2 & 0.8 & -1.7 & 0.7 & -0.4 & -0.9 & & & & \\
\hline - loans to the National Road Administration & & & 1.4 & 0.1 & 0.1 & 2.4 & 0.2 & 2.8 & -0.1 & & & & \\
\hline - decrease in government deposits in lei & 1.8 & -3.9 & -2.8 & -3.3 & 4.8 & -11.5 & 13.7 & 3.7 & -7.3 & & & & \\
\hline - decrease in government deposits in foreign currencie & -1.7 & -5.4 & 0.2 & -0.9 & -1.2 & -12.9 & 10.4 & -4.7 & 3.8 & & & & \\
\hline II. State Owned Enterprises Financing 4/ & 24.7 & 38.8 & 43.3 & 13.8 & 13.6 & 6.7 & 18.8 & 52.9 & -2.2 & 1.2 & 8.7 & 11.3 & 19.0 \\
\hline - percent of annual GDP & 3.1 & 3.3 & 2.9 & 0.7 & 0.7 & 0.4 & 1.0 & $\begin{array}{l}2.8 \\
1.4\end{array}$ & -0.1 & 0.1 & 0.4 & 0.5 & 0.8 \\
\hline 1. External Financing, net & 9.6 & 18.7 & 36.0 & 2.8 & 4.2 & 3.3 & 15.7 & 25.9 & 10.7 & 1.2 & 8.7 & 17.4 & 38.1 \\
\hline - bonds & -0.2 & 7.2 & 14.7 & 0.0 & 0.0 & 0.0 & 9.9 & 9.9 & 0.0 & -6.5 & 0.0 & 8.7 & 2.2 \\
\hline - state-guaranteed (excl. called guarantees) & -0.2 & 3.7 & 6.0 & 0.0 & 0.0 & 0.0 & 9.9 & 9.9 & 0.0 & -6.5 & 0.0 & 8.7 & 2.2 \\
\hline - without state guarantee & 0.0 & 3.4 & 4.1 & 0.0 & 0.0 & 0.0 & 0.0 & 0.0 & 0.0 & & & & 0.0 \\
\hline - loans & 9.9 & 11.5 & 21.3 & 2.8 & 4.2 & 3.3 & 5.8 & 16.0 & 10.7 & 7.7 & 8.7 & 8.7 & 35.9 \\
\hline - state-guaranteed (excl. called guarantees) & 8.9 & 9.7 & 19.5 & 2.8 & 4.1 & 3.2 & 5.9 & 15.9 & 8.0 & 7.7 & 8.7 & 8.7 & 33.1 \\
\hline - without state guarantee & 1.0 & 1.9 & 1.9 & 0.0 & 0.1 & 0.1 & -0.1 & 0.1 & 2.7 & & & & 2.7 \\
\hline 2. Bank Financing 1/, 10/ & -0.7 & 2.2 & -10.8 & 5.0 & 6.4 & 1.4 & -0.3 & 12.4 & -13.7 & 1.0 & 1.0 & -5.1 & -16.8 \\
\hline - increase in credit to SOEs & -0.2 & 4.0 & 5.3 & -1.4 & 1.5 & -0.2 & 3.6 & 3.5 & -3.6 & -0.5 & 0.0 & 0.0 & -4.1 \\
\hline - decrease in SOEs deposits & -0.5 & -1.8 & -16.1 & 6.4 & 4.9 & 1.6 & -3.9 & 8.9 & -10.1 & 1.5 & 1.0 & -5.1 & -12.7 \\
\hline 3. Accumulation of Arrears & 15.7 & 17.9 & 18.1 & 6.1 & 3.0 & 2.1 & 3.4 & 14.6 & 0.8 & -1.1 & -1.0 & -1.0 & -2.3 \\
\hline $\begin{array}{l}\text { - to the general government } 9 / \\
\text { - to the private sector }\end{array}$ & 15.7 & 17.9 & 18.1 & 6.1 & 3.0 & 2.1 & 3.4 & 14.6 & 0.8 & -1.1 & -1.0 & -1.0 & -2.3 \\
\hline III. Overall Public Sector Financing 5/ & 43.5 & 54.0 & 67.0 & 10.3 & 15.3 & -0.9 & 37.3 & 61.9 & 3.9 & 19.3 & 14.6 & 30.7 & 68.4 \\
\hline - percent of annual GDP & 5.4 & 4.6 & 4.4 & 0.5 & 0.8 & 0.0 & 2.0 & 3.3 & 0.2 & 0.9 & 0.6 & 1.4 & 3.0 \\
\hline 1. External Financing, net & 32.2 & 44.2 & 59.6 & 6.3 & 5.7 & 34.9 & 10.5 & 57.4 & 11.8 & 32.9 & 16.6 & 15.9 & 77.3 \\
\hline 2. Non-Bank Financing & 19.4 & 19.5 & 21.2 & 6.2 & -2.3 & 2.6 & 3.4 & 10.0 & 10.3 & 2.2 & 9.8 & 2.3 & 24.6 \\
\hline 3. Bank Financing & -8.0 & -9.7 & -13.8 & -2.2 & 11.9 & -38.4 & 23.4 & -5.4 & -18.3 & -15.8 & -11.8 & 12.5 & -33.4 \\
\hline Public Sector Borrowing Requirement 6/ & 35.9 & 47.8 & 57.2 & 8.2 & 13.7 & -2.0 & 35.7 & 55.6 & 1.9 & 17.9 & 5.6 & 29.2 & 54.6 \\
\hline - percent of annual GDP & 4.5 & 4.1 & 3.8 & 0.4 & 0.7 & -0.1 & 1.9 & 2.9 & 0.1 & 0.8 & 0.2 & 1.3 & 2.4 \\
\hline \multicolumn{14}{|l|}{ Memorandum Items: } \\
\hline $\begin{array}{l}\text { General Government Deficit (above the line), percent } \\
\text { of annual GDP }\end{array}$ & 4.0 & 3.2 & 2.6 & 0.3 & 0.5 & -0.2 & 1.6 & 2.3 & 0.4 & 0.6 & 0.3 & 0.8 & 2.1 \\
\hline \multicolumn{14}{|l|}{ Discrepancy (above-the-line minus below-the line } \\
\hline General Government Deficit) & -0.3 & 2.5 & 2.0 & 0.2 & 0.3 & 0.1 & 0.4 & 1.1 & 0.1 & -0.2 & 0.1 & 0.0 & 0.0 \\
\hline Cash Financing of the SOEs, percent of annual GDP & 1.1 & 1.8 & 1.7 & 0.4 & 0.6 & 0.2 & 0.8 & 2.0 & -0.1 & 0.1 & 0.4 & 0.6 & 1.0 \\
\hline GDP (annual) & 804 & 1,167 & 1,512 & 1,891 & 1,891 & 1,891 & 1,891 & 1,891 & 2,243 & 2,243 & 2,243 & 2,243 & 2,243 \\
\hline Average Exchange Rate (LEI/US\$) & 21,693 & 29,060 & 33,055 & 33,155 & 32,940 & 33,278 & 33,428 & 33,201 & 32,430 & .. & .. &.. & \\
\hline
\end{tabular}

1/ Calculated as difference between the end-of-period stocks. The foreign currency flows are converted in lei at the monthly average exchange rate. 2/ From the monetary survey.

3/ T-bills issued domestically by the Ministry of Finance.

4/ Including borrowing not guaranteed by the state

5 / Excludes arrears to the general government.

6/ Excludes non-debt-creating financing.

7/ Total privatization receipts of all components of the consolidated general government independent of whether they are transferred to the treasury.

8/ AVAS receipts from asset recovery transferred to the consolidated general government.

9/ Estimates for 2001 and Q3-Q4'2003.

10/ Excludes lending to the National Road Administration in 2003 and 2004. 
Table 13. Romania: Schedule of Purchases Under the Stand-By Arrangement

\begin{tabular}{|c|c|c|c|}
\hline Date & $\begin{array}{l}\text { Amounts } \\
\text { in millions } \\
\text { of SDRs }\end{array}$ & $\begin{array}{l}\text { In percent } \\
\text { of quota }^{7}\end{array}$ & Conditions \\
\hline July 8, 2004 & 27.778 & 2.70 & Board approval of Stand-By Arrangement \\
\hline August 15, 2004 & 27.778 & 2.70 & $\begin{array}{l}\text { Observance of end-June quantitative } \\
\text { performance criteria, structural performance } \\
\text { criteria and completion of quarterly review }\end{array}$ \\
\hline November 15, 2004 & 27.778 & 2.70 & $\begin{array}{l}\text { Observance of end-September performance } \\
\text { criteria and completion of quarterly review }\end{array}$ \\
\hline February 15,2005 & 27.778 & 2.70 & $\begin{array}{l}\text { Observance of end-December performance } \\
\text { criteria and completion of quarterly review }\end{array}$ \\
\hline May 15,2005 & 27.778 & 2.70 & $\begin{array}{l}\text { Observance of end-March performance } \\
\text { criteria and completion of quarterly review }\end{array}$ \\
\hline August 15, 2005 & 27.778 & 2.70 & $\begin{array}{l}\text { Observance of end-June performance } \\
\text { criteria and completion of quarterly review }\end{array}$ \\
\hline November 15, 2005 & 27.778 & 2.70 & $\begin{array}{l}\text { Observance of end-September performance } \\
\text { criteria and completion of quarterly review }\end{array}$ \\
\hline February 15, 2006 & 27.778 & 2.70 & $\begin{array}{l}\text { Observance of end-December performance } \\
\text { criteria and completion of quarterly review }\end{array}$ \\
\hline May 15, 2006 & 27.776 & 2.70 & $\begin{array}{l}\text { Observance of end-March performance } \\
\text { criteria and completion of quarterly review }\end{array}$ \\
\hline $\begin{array}{l}\text { Total Under } \\
\text { Arrangement }\end{array}$ & 250 & 24.27 & \\
\hline
\end{tabular}

\footnotetext{
${ }^{7}$ The quota is SDR 1,030.2 million.
} 


\section{ROMANIA-RELATIONS WITH THE FUND \\ (As of April 30, 2004)}

I. Membership Status: Joined 12/15/72; Article VIII

II. General Resources Account:

Quota

Fund holdings of currency

III. SDR Department:

Net cumulative allocation

Holdings

IV. Outstanding Purchases and Loans:

Stand-By Arrangements

Systemic Transformation $\underline{\text { SDR million }}$

$1,030.20$

$1,406.88$

$\frac{\text { SDR million }}{75.95}$

2.75

$\frac{\text { SDR million }}{360.97}$

15.71 $\frac{\% \text { Quota }}{100.00}$

136.56

$\frac{\% \text { Allocation }}{100.00}$

3.62

$\frac{\% \text { Quota }}{35.04}$

1.52

V. Financial Arrangements:

Type

Stand-By

Stand-By

Stand-By

Stand-By

Stand-By

Stand-By

\begin{tabular}{|c|c|c|c|}
\hline & $\begin{array}{l}\text { Expira- } \\
\text { tion }\end{array}$ & $\begin{array}{l}\text { Amount } \\
\text { Approved }\end{array}$ & $\begin{array}{c}\text { Amount } \\
\text { Drawn }\end{array}$ \\
\hline & Date & (SDR million) & (SDR million) \\
\hline
\end{tabular}

$\begin{array}{lll}10 / 31 / 01 & 10 / 15 / 03 & 300.00 \\ 08 / 05 / 99 & 02 / 28 / 01 & 400.00 \\ 04 / 22 / 97 & 05 / 21 / 98 & 301.50 \\ 05 / 11 / 94 & 04 / 22 / 97 & 320.50 \\ 05 / 29 / 92 & 03 / 28 / 93 & 314.04 \\ 04 / 11 / 91 & 04 / 10 / 92 & 380.50\end{array}$

300.00

139.75

120.60

94.27

261.70

318.10

\section{Projected Payments to Fund (Expectations Basis) ${ }^{1}$}

(SDR million; based on existing use of resources and present holdings of SDRs):

\begin{tabular}{lrrrrrr} 
& \multicolumn{5}{c}{ Forthcoming } & \\
& $\underline{2004}$ & $\underline{2005}$ & $\underline{2006}$ & $\underline{2007}$ & $\underline{2008}$ \\
Principal & 91.32 & 102.80 & 113.67 & 68.89 & \\
Charges/interest & 6.69 & 6.80 & 4.25 & 2.02 & 1.19 \\
Total & 98.02 & 109.60 & 117.91 & 70.91 & 1.19
\end{tabular}

\footnotetext{
${ }^{1}$ This schedule presents all currently scheduled payments to the IMF, including repayment expectations where applicable and repayment obligations otherwise. The IMF Executive Board can extend repayment expectations (within predetermined limits) upon request by the debtor country if its external payments position is not strong enough to meet the expectations without undue hardship or risk.
} 


\section{Exchange Rate Arrangements}

From August 1994, a decentralized direct dealing interbank market has been in operation. The official reference rate published by the NBR is an average of rates reported for interbank and client transactions. Romania has accepted the obligations of Article VIII, Sections 2, 3, and 4, with effect from March 25, 1998. Romania's exchange system is free of restrictions on the making of payments and transfers for current international transactions. Romania maintains de jure a managed floating exchange rate regime with no preannounced exchange rate path, while the de facto regime is an unannounced crawling band.

\section{Article IV Consultation}

Romania is on the 24-month consultation cycle subject to the provisions of the decision on consultation cycles approved by the Board on July 15, 2002. The last consultation was concluded on January 8, 2003.

\section{Technical Assistance}

The transition in Romania has been supported by substantial technical assistance from multilateral agencies and bilateral donors. The Fund has provided support in a number of areas with more than 40 technical assistance missions since 1990, although the authorities have had a mixed record with regard to implementation. Expert Fund assistance has focused on a number of key areas, including: fiscal reforms; modernization of the central bank and the banking system; creating a market-oriented legal structure; training; and improving the collection and reporting of statistics. The implementation of a comprehensive tax administration reform designed in line with the recommendations of several technical assistance missions of the Fund's Fiscal Affairs Department has started in January 2003. A report on the observance of standards and codes (ROSC) on fiscal transparency was completed on November 6, 2002 (IMF Country Report No. 02/254).

\section{Safeguards Assessment}

Under the Fund's safeguards assessment policy, the NBR is subject to an assessment with respect to the new precautionary Stand-By Arrangement, which is currently being finalized by the staff. The preliminary conclusions do not indicate material weaknesses in the safeguards in place at the NBR. Moreover, staff found a substantial strengthening of the NBR's safeguards framework since the last assessment, which was completed in 2002 under the previous SBA for Romania.

\section{Resident Representative}

The Fund has had a resident representative in Bucharest since 1991. Mr. Graeme Justice assumed the post in January 2003. 


\section{ROMANIA: RELATIONS WITH THE WORLD BANK}

\section{Partnership in Romania's Development Strategy}

1. The Romanian authorities are pursuing a strategy designed to maintain macroeconomic stability and establish sustainable economic growth and poverty reduction, moving towards the eventual goal of accession to the European Union. Key elements of this policy include tightening payments discipline throughout the economy, especially in the energy sector, hardening budget constraints for state-owned enterprises, actively pursuing enterprise and banking privatization and restructuring, and strengthening the social safety net. Over the medium term, continuation of the current economic recovery will depend critically on the maintenance of reform momentum and moving steadily ahead with governance and private sector development reforms. Such reforms would stress transparency and accountability in government, improvements in the business environment, and actions to strengthen the regulation and oversight of financial and capital markets.

2. In broad terms, the IMF has taken the lead in assisting Romania in maintaining macroeconomic stability. As such its program focus is on the fiscal framework, monetary policy and those elements of the structural reform program that have a direct bearing on the macroeconomic situation. The main vehicles for its dialogue with the authorities are the recently completed Stand-By Arrangement (SBA) covering the period October 31, 2001 to October 15, 2003 and the proposed precautionary SBA

3. The World Bank has taken the lead in policy dialogue on structural issues, including poverty reduction measures, private sector development, institution building and governance. It has a range of instruments through which it conducts dialogue, including adjustment lending operations such as PSAL 1 and PSAL 2, a planned series of Programmatic Adjustment Loans, several sector investment operations and economic work such as the recently completed Public Expenditure and Institutions Review (PEIR), and the Country Economic Memorandum (CEM).

4. In some areas where the Bank takes the lead in the dialogue, its analysis is shared with the IMF and is used as input for the fiscal framework, but there are no directly corresponding structural benchmarks or policy conditions in the IMF SBA. In other areas where the Bank takes the lead, the SBA does reflect certain elements in its conditionality. These are generally structural reform measures which have important fiscal implications, such as energy sector reform and restructuring. There are further areas of formal joint responsibility such as the Financial Sector Assessment Program (FSAP).

5. Overall the IMF and World Bank staff maintain a close collaborative relationship in supporting the Government's reform program and are coordinating their policy advice to the Romanian authorities. 


\section{A. IMF-World Bank Collaboration in Specific Areas}

\section{Areas in which the World Bank leads and there is no direct IMF involvement}

6. The policy areas in which the Bank leads and which are not directly incorporated into the IMF program or country dialogue include strengthening the social safety net, revitalizing the economy in rural areas, institution building and governance, and improving the business environment. Bank policy dialogue for strengthening the social safety net includes poverty monitoring, social assistance, pension reform, child welfare reform, health sector reforms, and labor retraining and redeployment. These have been supported by the Bank's Employment and Social Protection Loan, the Social Sector Development Loan, the Social Development Fund and the Mine Closure Loan. They are further supported by economic work such as the recently completed Poverty Profile and the Local Services Delivery Study, and by planned economic studies on poverty and vulnerability, pension reform and gender assessment.

7. The Bank has a range of programs to revitalize the economy in rural areas. These include the Rural Finance Loan which supports income generation activities and will be complemented by a Rural/Urban Linkage Growth Study to set the stage for a Rural Development Loan supporting infrastructure development and improved governance at the community level. The Irrigation Rehabilitation loan supports infrastructure rehabilitation and institutional reform. Other supporting economic work includes the Community Networks Study and the Jiu Valley Development Study.

8. The Bank has a strong institution building and governance program. This builds on recent reforms in local public finance and taxation and decentralization. Policy dialogue has been facilitated the Public Expenditure and Institutions Review (PEIR) which included analysis and recommendations relating to 1) improved resource allocation in the health sector; 2) delivery of social assistance at the local level; 3) pension reform; 4) institutions for budget management 5) fiscal decentralization; and 6) reforms to the budget process in the judiciary. The policy dialogue has also been supported by a Country Financial Accountability Assessment (CFAA). The Bank completed a Diagnostic Survey of Corruption in Romania prior to the Government's preparing of its National Program for Prevention of Corruption. A series of Programmatic Adjustment Loans (PAL) will be launched shortly. These will focus on institutional and governance reforms in the public service and the judiciary as well as public expenditure management as well as the remaining structural reform agenda. They will be supported by a $\$ 18.6$ million Private and Public Sector Institution Building Loan (PPIBL) which will provide technical assistance for these activities and others relating to privatization. Other institution-building support includes financing of a cadastral and land titling project, a project on the environmental aspects of mine closures, a hazards mitigation project cofinanced by a GEF grant which focuses on damage from earthquakes, floods toxic wastes and other hazards in high risk areas, and by a regional project on Trade and Transportation Facilitation in South East Europe. 
9. Policy advice and support for reforms in the business environment have been offered by the Bank in several areas. Through PSAL 1 and PSAL 2 the Bank has focused on reducing barriers to entry for firms and joint ventures, implementing internationally recognized accounting standards and introducing improved bankruptcy and liquidation procedures. The PALs will also address business environment issues, and all these initiatives will be supported by technical assistance provided under the PPIBL.

\section{Areas in which the World Bank leads and its analysis serves as input into the IMF program}

10. The Bank supports the GOR's privatization program through PSAL 2 which includes targets and timelines for privatization of commercial SOEs and financial institutions. The program builds on the progress established under PSAL 1 and identifies pools of SOEs from which set minimum numbers of enterprises are selected for case-by-case privatization and workout. Specific enterprises including Alro, Alprom, and Petrom, were also identified. Key to the success of this program is agreement with the Bank on strategies for the privatization of theses entities and the subsequent adoption of a clear, open and transparent tender process using the services of qualified investment advisors in a manner consistent with Bank policies.

11. The Bank has led the dialogue on restructuring, reform and eventual privatization of enterprises in the electricity, district heating and gas industries and on the adoption of regulatory legislation in preparation for privatization to strategic investors. As part of this process the Bank is supporting, inter alia, energy tariff reforms and the elimination of arrears in the electricity, district heat and gas sectors, and these objectives are woven into the policy conditions of PSAL 2, along with conditions related to the privatization of electricity distribution enterprises. These conditions have been closely coordinated with the IMF since the SBA also includes provisions for structural reforms in the energy sector including tariff setting, arrears clearance and collection rates. The Bank is leading the IFI dialogue with the Government on such critical long-term issues as power generation sector restructuring and the integration of the Romanian power sector with the South East European Regional Electricity Market and with the EU's electricity market, and provides assistance on the associated regulatory and market operation issues. The Bank has also provided technical assistance to the Ministry of Industry to establish a system of pricing and taxation of gas consistent with attracting further investment into the industry. Policy dialogue in these and other areas, notably including the district heating sector, will be further facilitated by ongoing dialogue with the Government on the recently completed Energy and Infrastructure Strategy paper and its operational recommendations. Again, the series of PALs will be used as vehicles for incorporating policy advice in these areas into Bank lending operations.

12. The Bank has taken the lead in dialogue and policy advice regarding regulation, restructuring, privatization and liquidation of banks. Under PSAL 1 the Law on Bank Privatization was modified and transparent privatization procedures established. Liquidity and solvency requirements of the NBR were tightened and provisions introduced for improved compliance with prudential regulations and external audits conducted according to International Accounting Standards. Legal and institutional reforms were introduced for 
orderly disposition of non-performing assets. These policy changes underpinned liquidation of the most troubled bank (Bancorex ) while Bank Agricola was restructured and eventually privatized as were two smaller state owned banks. This policy agenda is continued under proposed PAL with steps to complete the sale of Banca Comerciala Romana (BCR) the Savings Bank (CEC). The Bank is continuing dialogue with the government on the need to move forward with further improvements of the legal and regulatory framework for the securities and insurance sectors. The PPIBL will provide funding for these activities.

\section{Areas of shared responsibility}

13. While the Bank has taken the lead in privatization and in structural reforms in the energy sector as described above, the IMF has a strong interest from a macroeconomic perspective since privatization revenues are used to retire public debt, and quasi-fiscal deficits of the SOEs present a threat to macroeconomic stability. Accordingly, there is high degree of consultation and coordination between the two institutions on these matters. The IMF has introduced into its SBA conditions relating to electricity tariff rates, arrears in gas and electricity collections as well as the privatization of a subset of the enterprises covered under the Bank's program. While the terms of the respective programs are mutually consistent and supportive, the focus and motivation for the Bank's program are on the efficiency of the resulting market structures, improved enterprise operation, service delivery and financial performance, and the transparency of the process and improvement in overall sector governance, and that of the IMF are on immediate revenue generation and expenditure control, and containment of ongoing fiscal burdens.

14. The Bank and the IMF jointly conducted a Financial Sector Assessment Program which was completed in June 2003.

\section{Areas in which the IMF leads and its analysis serves as input into the World Bank program}

15. While the Bank has focused on simplifications to the taxation system as a means of improving the business environment the Fund leads the dialogue on fiscal matters. In addition to the achievement of overall fiscal targets the Fund's Stand-By program includes structural benchmarks and performance criteria relating to introduction of new VAT and profits tax laws, increases in specific excises, and elimination of tax preferences under the customs duty and profit tax systems. The IMF is also providing technical assistance in support of unification of the payroll tax systems.

16. The IMF leads the dialogue on certain polices to contain certain expenditures in the public sector. These include policies regarding wage-setting in both the public service and SOEs and the budgets of SOEs In addition the IMF has lead the discussions relating to requirements for disconnections of non-payers in the gas and electricity sectors.

17. In these areas the Bank takes into account the policy recommendations of the IMF and ensures that its own policy advice is consistent. 


\section{Areas in which the IMF leads and there is no direct World Bank involvement}

18. The IMF is fully responsible for the dialogue on monetary policy, interest rates, the exchange rate regime, the balance of payments and all the related statistical and measurement issues.

\section{B. World Bank Group Strategy and Lending Operations}

19. A Country Assistance Strategy (CAS) for Romania was presented to the World Bank's Board on June 19, 2001. The CAS defines the Bank's lending and advisory services based on the Government's priorities of poverty reduction and EU accession, and builds on the work initiated under the Comprehensive Development Framework, for which Romania was one of the pilot countries. About one half of the FY02-04 lending program is adjustment lending. Two distinct lending scenarios were outlined. A low case in which Romania in the event of a hesitant pace of reforms would result in significant reductions in Bank Group support to a level of $\$ 60$ million during FY02-04 with actions centered on a few poverty focused interventions. However, Romania has successfully remained in the high-case lending scenario under which Bank commitments of up to \$995 million during FY02-04 were envisaged, compared with $\$ 600$ million in FY98-00. This reflects the sustained fulfillment of the high-case triggers, which included progress in establishing a macroeconomic environment conducive to lower inflation and sustainable growth as well as progress on structural issues including privatization as initiated under PSAL 1, initiation of the privatization and work-out process for a number of remaining large state-owned enterprises, agreement on a plan and schedule for reducing energy arrears, agreement on a method and timetable for privatization of Romanian Commercial Bank and the Savings Bank, improvements in the financial sector legal and supervisory framework, an agreement on an anti-corruption strategy, and approval of social assistance legislation.

20. The high-case scenario embodies a program of accelerated structural and sectoral reforms that will pave the way for Romania's eventual accession to the EU. The first stage of this program has now been launched with the approval of PSAL 2 by the Bank Board in September 2002, and the delivery of the Public Expenditure and Institutions Review (PEIR) in July 2002. In the second stage to follow PSAL 2, the Bank would offer support through a series of Programmatic Adjustment Loans (PALs) focusing on institutional and governance reforms, completion of the privatization agenda, implementation of the recommendations of the Energy and Infrastructure Strategy Paper and improvements to the business environment, as well as a Country Financial and Accountability Assessment and a Country Economic Memorandum focusing on the reform agenda for Romania's accession to the EU.

21. The World Bank has been active in Romania since 1991 and has built up a portfolio of 39 Bank-financed operations with total commitments of US\$3.9 billion. Romania's portfolio is the second largest in ECA in terms of number of projects and the fourth largest in terms of commitments. The active portfolio as of April 30, 2004 consists of 19 projects with aggregate net commitments totaling $\$ 1,144.7$ million and a total undisbursed balance of 
$\$ 749.2$ million. Sector composition in terms of net commitments is dominated by energy and infrastructure (42 percent, seven projects) and the social sectors (15 percent, four projects).

22. The quality of the Bank's Romania portfolio has been improving over the past several years. While the overall performance indicators are positive, several cross-cutting implementation issues persist. These include: (i) project management capacity (specifically, issues relating to procedures, inter-agency coordination, and project implementation unit staffing and facilities), and (ii) the timely availability of counterpart contributions as well as the quality and processing of disbursement applications, to yield maximum development impact from the Bank's portfolio.

23. IFC has dedicated substantial resources to implementing a strategy intended to advance structural reform, assist the development of capital markets and infrastructure (utilities and telecommunication), and provide support for small and medium enterprises (SMEs). To date, IFC has committed US\$393 million in 26 projects. As of end December 2003, IFC portfolio in Romania stood at $\$ 267$ million. In addition to investments, IFC has undertaken a number of advisory assignments aimed at supporting the privatization and restructuring of large state-owned enterprises, public utilities and the health sector.

Questions may be referred to Ron Hood (473-0115) or Myla Williams (473-6997) 


\section{ROMANIA: STATISTICAL ISSUES}

1. Romania's data collection and reporting is adequate for surveillance and program monitoring. The authorities have made progress improving their economical and financial database with the help of Fund TA missions, although more needs to be done in the areas of balance of payments and fiscal statistics, and ensuring the consistency between monetary and fiscal data. Romania has participated in the GDDS since February 2001. The November 2000 STA mission assisted the authorities in preparing GDDS metadata and prepared a ROSC for the data module which is now posted on the IMF website. An STA monetary and financial statistics mission visited Bucharest during May 11-23, 2003 to review the status of the GDDS Plans for Improvement for the National Bank of Romania (NBR) and assist in adopting the recommendations of the IMF's Monetary and Financial Statistics Manual (MFSM). A BOP mission between June 23-July 8, 2003 undertook a detailed review of the compilation methodology on the balance of payments and the international investment position. Romania nominated an SDDS Coordinator in October 2003 and is currently working towards SDDS subscription.

\section{Real Sector}

2. The quarterly and annual national accounts statistics produced by the National Institute for Statistics (INS) are methodologically sound and are reported to the Fund on a timely basis for publication in the International Financial Statistics (IFS). However, harmonization of quarterly and annual national accounts is not done on a regular basis and late revisions can sometimes be significant. The INS has moved to update the framework from the European System of Accounts 1979 (ESA79) to ESA95; ESA95-based data were released at end-2000. Constant price estimates are in the process of being converted to annual chain-linked indices, as recommended by ESA95. The INS staff has been downsized significantly over the past few years, which might affect the quality and timeliness of the data in the period ahead.

3. The Consumer Price Index (CPI) is subject to standard annual re-weighting, and it is considered to be reliable. Based on technical assistance recommendations from the European Union's PHARE Program, the INS reduced the coverage of the Producer Price Index (PPI) from the value of all shipments of the covered industries to shipments for domestic uses only beginning with 1998 data. As of January 2004 the INS changed the coverage of the PPI back to include the domestic and non-domestic markets.

\section{Public Finance}

4. Consolidated data on central government operations are reported annually for the GFS Yearbook and quarterly for $I F S$, while EUR receives monthly budget data. The STA multisector statistics mission that visited Romania in December 1999 recommended that all major fiscal categories be reported on a quarterly and monthly basis. The mission also called for the documentation and reporting of all government transactions related to the Agency for Bank Asset Recovery (AVAB) which has received large amounts of nonperforming bank claims in exchange for the 'bank receipts of government securities. The mission also 
recommended the introduction of detailed financing and debt classifications in the Treasury's chart of accounts and budget classifications, but these recommendations have yet to be implemented. Work continues on the establishment of a new aid coordination unit to monitor external grants.

\section{Monetary and Financial}

5. The NBR reports monetary and financial statistics on a regular and timely basis for publication in the IFS. The overall assessment of the May 2003 monetary and financial statistics mission is that the NBR has implemented important recommendations of previous STA missions in the area of monetary statistics. The monetary statistics compiled and disseminated by the NBR meet, and in some instances exceed, the recommendations of the GDDS with respect to coverage, periodicity, and timeliness of dissemination.

6. Nevertheless, monetary statistics needs to be reconciled with government finance statistics. In line with 1993 SNA and MFSM, accrued interest on deposits and loans, and securities other than shares should be incorporated in the outstanding amount of financial assets or liquidity.

7. With the gradual harmonization of Romania's monetary and financial statistics with the 1995 ESA and European Central Bank statistical reporting requirements, important deviations from the IMF's statistical methodology are expected to diminish over time as a result of the strong concordance among the 1995 ESA, 1993 SNA, and MFSM.

\section{Balance of Payments}

8. The NBR routinely reports balance of payments statistics to the Fund in a timely fashion. Data collection and compilation have improved following technical assistance. The ROSC data module of November 2001 noted particular concerns with the coverage of the direct investment data (stocks and flows) and related income flows, and with the quality of data on current transfers, in particular with the general government sector. The NBR has decided to adopt a new balance of payments compilation system in consultation with Eurostat. In July 2003, a balance of payments statistics mission concluded that the proposed system is broadly appropriate. The mission supported the implementation of the new system in 2004 along with the conduct of the new FDI survey. A switch from annual to quarterly frequency in the outward portfolio survey could also be considered for implementation in 2004 (or later) as well as the collection of stock data on equity securities via the National Commission of Securities. 
Table 14. Romania: Core Statistical Indicators as of June 10, 2004

\begin{tabular}{|c|c|c|c|c|c|c|c|c|c|c|c|c|}
\hline & $\begin{array}{c}\text { Exchange } \\
\text { Rates }\end{array}$ & $\begin{array}{l}\text { Interna- } \\
\text { tional } \\
\text { Reserves }\end{array}$ & $\begin{array}{c}\text { Central } \\
\text { Bank } \\
\text { Balance } \\
\text { Sheet }\end{array}$ & $\begin{array}{c}\text { Reserve/ } \\
\text { Base } \\
\text { money }\end{array}$ & $\begin{array}{l}\text { Broad } \\
\text { Money }\end{array}$ & $\begin{array}{c}\text { Interest } \\
\text { Rates }\end{array}$ & \begin{tabular}{|c|} 
Consumer \\
Price \\
Index
\end{tabular} & $\begin{array}{l}\text { Exports/ } \\
\text { Imports }\end{array}$ & $\begin{array}{l}\text { Current } \\
\text { Account } \\
\text { Balance }\end{array}$ & \begin{tabular}{|c|} 
Overall \\
Govern- \\
ment \\
Balance
\end{tabular} & $\begin{array}{l}\text { GDP/ } \\
\text { GNP }\end{array}$ & \begin{tabular}{|} 
External \\
Debt/ \\
Debt \\
Service
\end{tabular} \\
\hline $\begin{array}{l}\text { Date of Latest } \\
\text { Observation }\end{array}$ & $\begin{array}{c}\text { June } 9, \\
2004\end{array}$ & $\begin{array}{c}\text { June 4, } \\
2004\end{array}$ & $\begin{array}{l}\text { Apr. } \\
2004\end{array}$ & $\begin{array}{c}\text { June 4, } \\
2004\end{array}$ & $\begin{array}{l}\text { Apr. } \\
2004\end{array}$ & $\begin{array}{l}\text { Apr. } \\
2004\end{array}$ & $\begin{array}{l}\text { Apr. } \\
2004\end{array}$ & $\begin{array}{l}\text { Apr. } \\
2004\end{array}$ & $\begin{array}{l}\text { Mar. } \\
2004\end{array}$ & $\begin{array}{l}\text { Apr. } \\
2004\end{array}$ & $\begin{array}{c}2004 \\
\text { Q1 }\end{array}$ & $\begin{array}{l}\text { Mar. } \\
2004\end{array}$ \\
\hline Date Received & $\begin{array}{c}\text { June } 10, \\
2004\end{array}$ & $\begin{array}{c}\text { June } 7, \\
2004\end{array}$ & $\begin{array}{l}\text { May } \\
2004\end{array}$ & $\begin{array}{c}\text { June } 7, \\
2004\end{array}$ & $\begin{array}{l}\text { May } \\
2004\end{array}$ & $\begin{array}{l}\text { May } \\
2004\end{array}$ & $\begin{array}{l}\text { May } \\
2004\end{array}$ & $\begin{array}{l}\text { May } \\
2004\end{array}$ & $\begin{array}{l}\text { May } \\
2004\end{array}$ & $\begin{array}{l}\text { May } \\
2004\end{array}$ & $\begin{array}{l}\text { June } \\
2004\end{array}$ & $\begin{array}{l}\text { May } \\
2004\end{array}$ \\
\hline $\begin{array}{l}\text { Frequency } \\
\text { of Data }\end{array}$ & Daily & Daily & Monthly & Daily & Monthly & Monthly & Monthly & Monthly & Monthly & Monthly & Quarterly & Monthly \\
\hline $\begin{array}{l}\text { Frequency of } \\
\text { Reporting }\end{array}$ & Daily & Weekly & Monthly & Weekly & Monthly & Monthly & Monthly & Monthly & Monthly & Monthly & Quarterly & Monthly \\
\hline $\begin{array}{l}\text { Source of } \\
\text { Update }\end{array}$ & $\begin{array}{c}\text { National } \\
\text { Bank of } \\
\text { Romania }\end{array}$ & $\begin{array}{c}\text { National } \\
\text { Bank of } \\
\text { Romania }\end{array}$ & $\begin{array}{c}\text { National } \\
\text { Bank of } \\
\text { Romania }\end{array}$ & $\begin{array}{c}\text { National } \\
\text { Bank of } \\
\text { Romania }\end{array}$ & $\begin{array}{c}\text { National } \\
\text { Bank of } \\
\text { Romania }\end{array}$ & $\begin{array}{c}\text { National } \\
\text { Bank of } \\
\text { Romania }\end{array}$ & $\begin{array}{c}\text { National } \\
\text { Institute } \\
\text { of } \\
\text { Statistics }\end{array}$ & $\begin{array}{c}\text { National } \\
\text { Institute } \\
\text { of } \\
\text { Statistic } \\
\mathrm{s}\end{array}$ & \begin{tabular}{|c|} 
National \\
Bank of \\
Romania
\end{tabular} & $\mathrm{MoF}$ & \begin{tabular}{|} 
National \\
Institute \\
of \\
Statistics
\end{tabular} & $\begin{array}{c}\text { National } \\
\text { Bank of } \\
\text { Romania/ } \\
\text { MoF }\end{array}$ \\
\hline $\begin{array}{l}\text { Mode of } \\
\text { Reporting }\end{array}$ & Electronic & Electronic & Electronic & $\begin{array}{c}\text { Electroni } \\
\mathrm{c}\end{array}$ & $\begin{array}{c}\text { Electroni } \\
\text { c }\end{array}$ & Electronic & Electronic & $\begin{array}{c}\text { Electron } \\
\text { ic }\end{array}$ & $\begin{array}{c}\text { Electroni } \\
\mathrm{c}\end{array}$ & $\begin{array}{c}\text { Electron } \\
\text { ic }\end{array}$ & $\begin{array}{c}\text { Electroni } \\
\mathrm{c}\end{array}$ & $\begin{array}{c}\text { Electroni } \\
\text { c }\end{array}$ \\
\hline Confidentiality & Published & Published & Published & $\begin{array}{c}\text { Publishe } \\
\mathrm{d}\end{array}$ & $\begin{array}{c}\text { Publishe } \\
\text { d }\end{array}$ & Published & Published & $\begin{array}{c}\text { Publishe } \\
\mathrm{d}\end{array}$ & $\begin{array}{c}\text { Publishe } \\
\mathrm{d}\end{array}$ & $\begin{array}{c}\text { Publishe } \\
\mathrm{d}\end{array}$ & $\begin{array}{c}\text { Publishe } \\
\mathrm{d}\end{array}$ & $\begin{array}{c}\text { Publishe } \\
\text { d }\end{array}$ \\
\hline $\begin{array}{l}\text { Frequency of } \\
\text { Publication }\end{array}$ & Daily & Monthly & Monthly & Monthly & Monthly & Monthly & Monthly & Monthly & Quarterly & Monthly & Quarterly & Quarterly \\
\hline
\end{tabular}




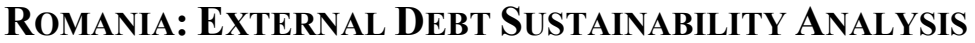

Following recent macroeconomic consolidation, Romania's external position appears robust. The external debt to GDP ratio under the baseline scenario is expected to remain at about 34 percent, the level at end-2003. Under standard stress tests, debt dynamics remain under control. Romania's gross external financing need is projected to remain stable relative to GDP throughout the projection period; under most of the stress tests it rises only marginally over the baseline.

The historical-average scenario (A1) shows results similar to the baseline, implying that forecasts are not overly optimistic. The debt-stabilizing level of the current account deficit is almost unchanged from the baseline, and the debt to GDP ratio rises to only 35 percent, compared to 34 percent under the baseline. The slight improvement in Romania's mediumterm prospects under the baseline over historical averages is justified due to continued structural reforms and conservative fiscal policies.

Even under the scenario of weak policy implementation (A2), debt levels and external financing needs do not rise far from the baseline. Romania's current-account deficit remains above 4 percent of GDP for 2004-2006, GDP growth is lower, and the adjustment currently envisioned for the program period is delayed. The gap relative to baseline is financed largely by debt-creating flows. However, while these factors cause a temporary deterioration in gross external financing, their effect on the debt ratio is minor compared to the baseline.

Among the standard stress tests (B1-B6), Romania's debt appears most vulnerable to a shock to GDP growth or worsening of the current account. Romania's GDP growth was fairly volatile during the past decade, which explains the large deviation under the slowgrowth scenario. The combined-shock scenario (lower U.S. inflation, larger Romanian current account deficit and slower GDP growth) increases the debt to GDP ratio to nearly 50 percent. Therefore, continued forbearance in consumption growth and the implementation of structural reforms to increase long-term growth potential are important to maintain Romania's sustainable position. 
Table 15. Romania: External Debt Sustainability Framework, 1999-2009

(In percent of GDP, unless otherwise indicated)

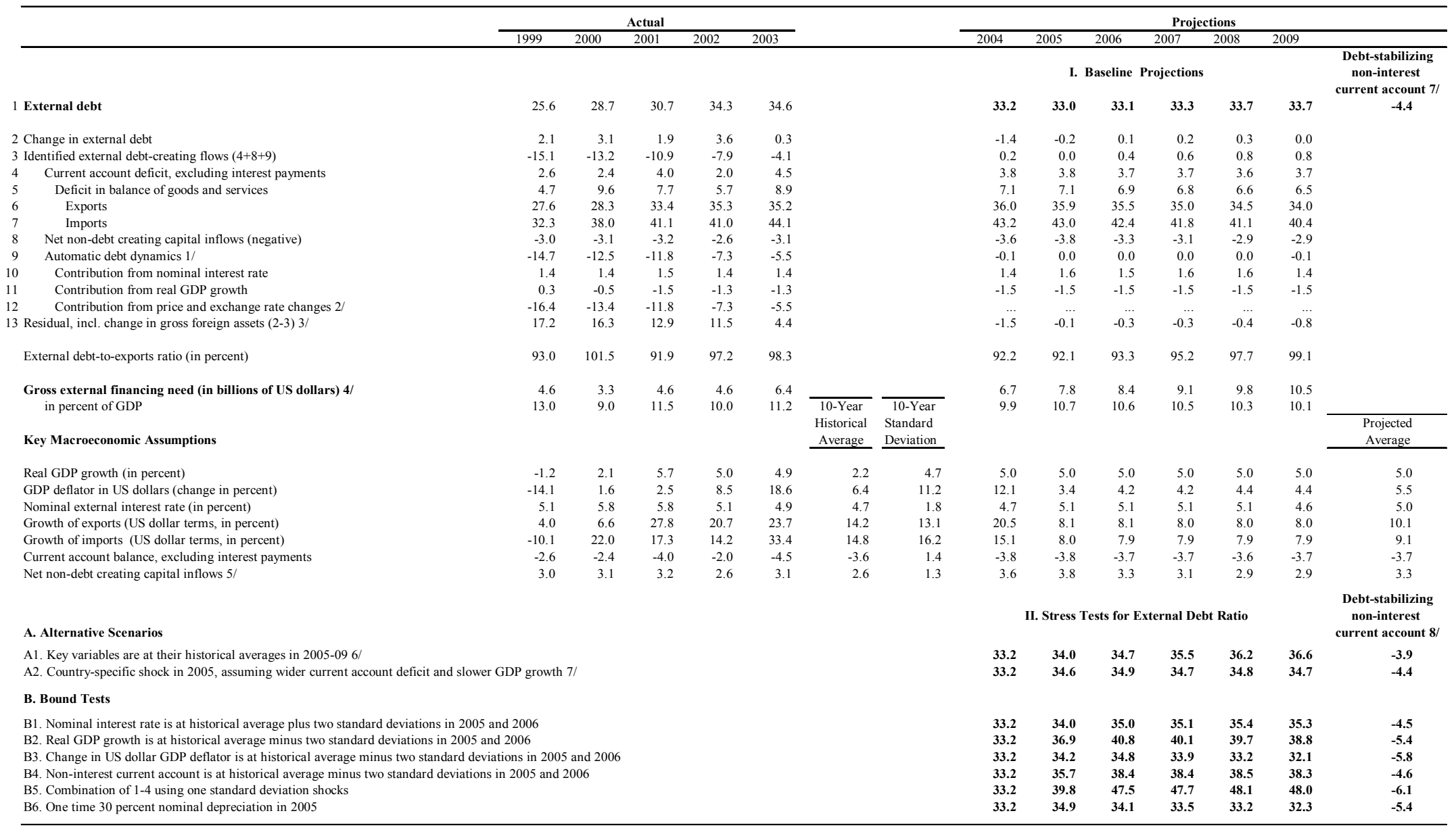

1/ Derived as $[\mathrm{r}-\mathrm{g}-\rho(1+\mathrm{g})+\varepsilon \alpha(1+\mathrm{r})](1+\mathrm{g}+\rho+\mathrm{g} \rho)$ times previous period debt stock, with $\mathrm{r}=$ nominal effective interest rate on external debt; $\rho=$ change in domestic GDP deflator in US dollar terms, $\mathrm{g}=$ real GDP growth rate,

$\mathrm{e}=$ nominal appreciation (increase in dollar value of domestic currency), and $\mathrm{a}=$ share of domestic-currency denominated debt in total external debt.

2/ The contribution from price and exchange rate changes is defined as $[-\rho(1+\mathrm{g})+\varepsilon \alpha(1+\mathrm{r})](1+\mathrm{g}+\rho+\mathrm{g} \rho)$ times previous period debt stock. $\rho$ increases with an appreciating domestic currency $(\varepsilon>0)$ and rising inflation (based on GDP deflator)

/ For projection, line includes the impact of price and exchange rate changes.

4/ Defined as current account deficit, plus amortization on medium- and long-term debt, plus short-term debt at end of previous period.

$5 /$ Includes foreign direct and portfolio investment, as well as capital transfers, including pre- and post-accession transfers from EU.

The key variables include real GDP growth; nominal interest rate; dollar deflator growth; and both non-interest current account and non-debt inflows in percent of GDP.

8/ Long-run, constant balance that stabilizes the debt ratio assuming that key variables (real GDP growth, nominal interest rate, dollar deflator growth, and non-interest current account and non-debt inflows in percent of GDP) remain at their levels

the last projection year. 
Table 16. Romania: External Sustainability Framework—Gross External Financing Need, 1999-2009

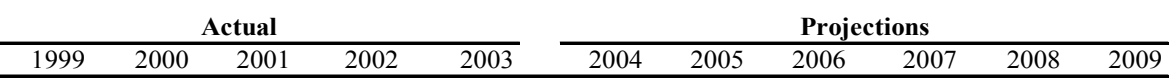

\begin{tabular}{|c|c|c|c|c|c|c|c|c|c|c|c|}
\hline $\begin{array}{l}\text { Gross external financing need in billions of U.S. dollars 1/ } \\
\text { in percent of GDP }\end{array}$ & $\begin{array}{r}4.6 \\
13.0\end{array}$ & $\begin{array}{l}3.3 \\
9.0\end{array}$ & $\begin{array}{r}4.6 \\
11.5\end{array}$ & $\begin{array}{r}4.6 \\
10.0\end{array}$ & $\begin{array}{r}6.4 \\
11.2\end{array}$ & $\begin{array}{l}6.7 \\
9.9\end{array}$ & $\begin{array}{r}7.8 \\
10.7\end{array}$ & $\begin{array}{r}8.4 \\
10.6\end{array}$ & $\begin{array}{r}9.1 \\
10.5\end{array}$ & $\begin{array}{r}9.8 \\
10.3\end{array}$ & $\begin{array}{l}10.5 \\
10.1\end{array}$ \\
\hline
\end{tabular}

Gross external financing need in billions of U.S. dollars 2/

II. Stress Tests

\section{A. Alternative Scenarios}

A1. Key variables are at their historical averages in 2005-09 3/

A2. Country-specific shock in 2005, with reduction in GDP growth (relative to baseline) of one standard deviation 4/

$\begin{array}{rrrrrr}6.7 & 7.7 & 8.5 & 9.2 & 9.9 & 10.7 \\ 6.7 & 8.8 & 8.9 & 9.3 & 9.7 & 10.4 \\ & & & & & \\ & & & & & \\ 6.7 & 8.6 & 9.5 & 9.4 & 10.1 & 10.9 \\ 6.7 & 7.4 & 7.6 & 8.1 & 8.6 & 9.1 \\ 6.7 & 6.7 & 5.9 & 6.1 & 6.4 & 6.7 \\ 6.7 & 10.0 & 11.4 & 10.0 & 10.7 & 11.5 \\ 6.7 & 8.6 & 8.9 & 9.3 & 10.0 & 10.8 \\ 6.7 & 6.1 & 6.3 & 6.7 & 7.1 & 7.5\end{array}$

B1. Nominal interest rate is at historical average plus two standard deviations in 2005 and 2006

B2. Real GDP growth is at historical average minus two standard deviations in 2005 and 2006

B3. Change in US dollar GDP deflator is at historical average minus two standard deviations in 2005 and 2006

B4. Non-interest current account is at historical average minus two standard deviations in 2005 and 2006

B5. Combination of 2-5 using one standard deviation shocks

B6. One time 30 percent nominal depreciation in 2005

\section{Gross external financing need in percent of GDP 2/}

\section{A. Alternative Scenarios}

A1. Key variables are at their historical averages in 2005-09 3/

A2. Country-specific shock in 2005, assuming wider current account deficit and slower GDP growth

$\begin{array}{rrrrrr}9.9 & 10.6 & 10.7 & 10.7 & 10.6 & 10.5 \\ 9.9 & 12.2 & 11.2 & 10.7 & 10.1 & 9.9 \\ & & & & & \\ 9.9 & 11.9 & 11.9 & 10.8 & 10.6 & 10.4 \\ 9.9 & 11.6 & 12.2 & 11.9 & 11.5 & 11.1 \\ 9.9 & 11.3 & 11.3 & 10.6 & 10.2 & 9.8 \\ 9.9 & 13.8 & 14.3 & 11.5 & 11.2 & 10.9 \\ 9.9 & 13.9 & 15.5 & 14.8 & 14.5 & 14.2 \\ 9.9 & 11.6 & 10.8 & 10.5 & 10.2 & 9.8\end{array}$

\section{B. Bound Tests}

B1. Nominal interest rate is at historical average plus two standard deviations in 2005 and 2006

B2. Real GDP growth is at historical average minus two standard deviations in 2005 and 2006

B3. Change in US dollar GDP deflator is at historical average minus two standard deviations in 2005 and 2006

B4. Non-interest current account is at historical average minus two standard deviations in 2005 and 2006

B5. Combination of 1-4 using one standard deviation shocks

B6. One time 30 percent nominal depreciation in 2005 
Figure 13. Romania: Debt Ratio and Gross External Financing Need, 2003-09
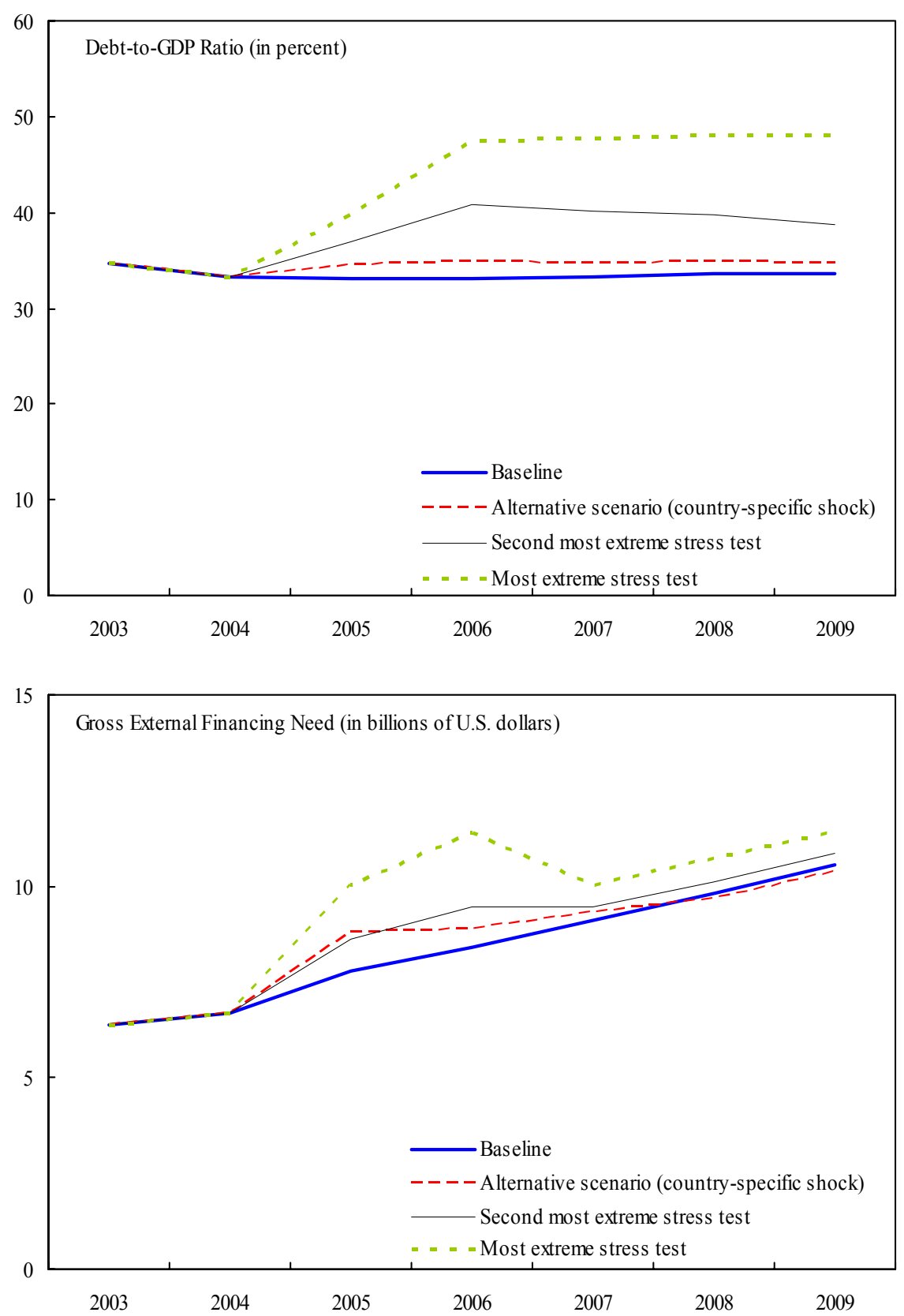

Source: IMF staff calculations. 


\section{FisCAL SUSTAINABILITY SimULATIONS}

Based on a continuing fiscal consolidation in the run up to $\mathrm{EU}$ accession, the debt to GDP ratio is projected to stay roughly stable under the governments' medium-term fiscal plans. The level of about 27 percent of GDP projected for end-2004 is low compared to most other transition countries. Stress tests indicate that the most likely shocks would increase the debt-to-GDP ratio only moderately. The combinations of shocks that could raise public debt to permanently higher levels are unlikely to occur.

The alternative scenarios appear to be benign. With key variables at their historical averages (Scenario A1), the public debt ratio drops considerably by 2009, but this is an artifact of the applied methodology, particularly the very low projection for the real interest rate. Similarly, the historical average nominal depreciation against the U.S. dollar is not a good guide for the future, as the depreciation rate has exhibited a declining trend since inflation was brought under control. Note that to mitigate these factors, all the alternative scenarios are based on historical averages for the last 3 years.

The bound tests do not raise concerns either. Using the standard assumption of a 30 percent sustained real depreciation in 2005, the debt-to-GDP ratio is projected to rise some 10 percentage points. The same follows from assumption that other debt creating flows increase by 10 percent of GDP in 2005 . These outcomes are judged moderate after such extreme shocks, which staff considers unlikely. Scenarios with a lower primary balance, lower GDP growth, or real interest rates at 5 percent for 2005-06 all increase public debt by less than 1.5 percentage points.

Nonetheless, further fiscal adjustment over the medium term is necessary to sustain rapid medium-term growth without jeopardizing hard-won progress in stabilization of the economy. The process of macroeconomic stabilization has not been completed and the credibility of fiscal policy is yet to be entrenched. With the expected further strengthening in private sector investment, fiscal policy will need to prevent widening in the external current account deficit. Medium-term fiscal plans should therefore aim at further reducing the general government deficit and improving the financial performance of state-owned enterprises. 
Table 17. Romania: Public Sector Debt Sustainability Framework, 1999-2009 (In percent of GDP, unless otherwise indicated)

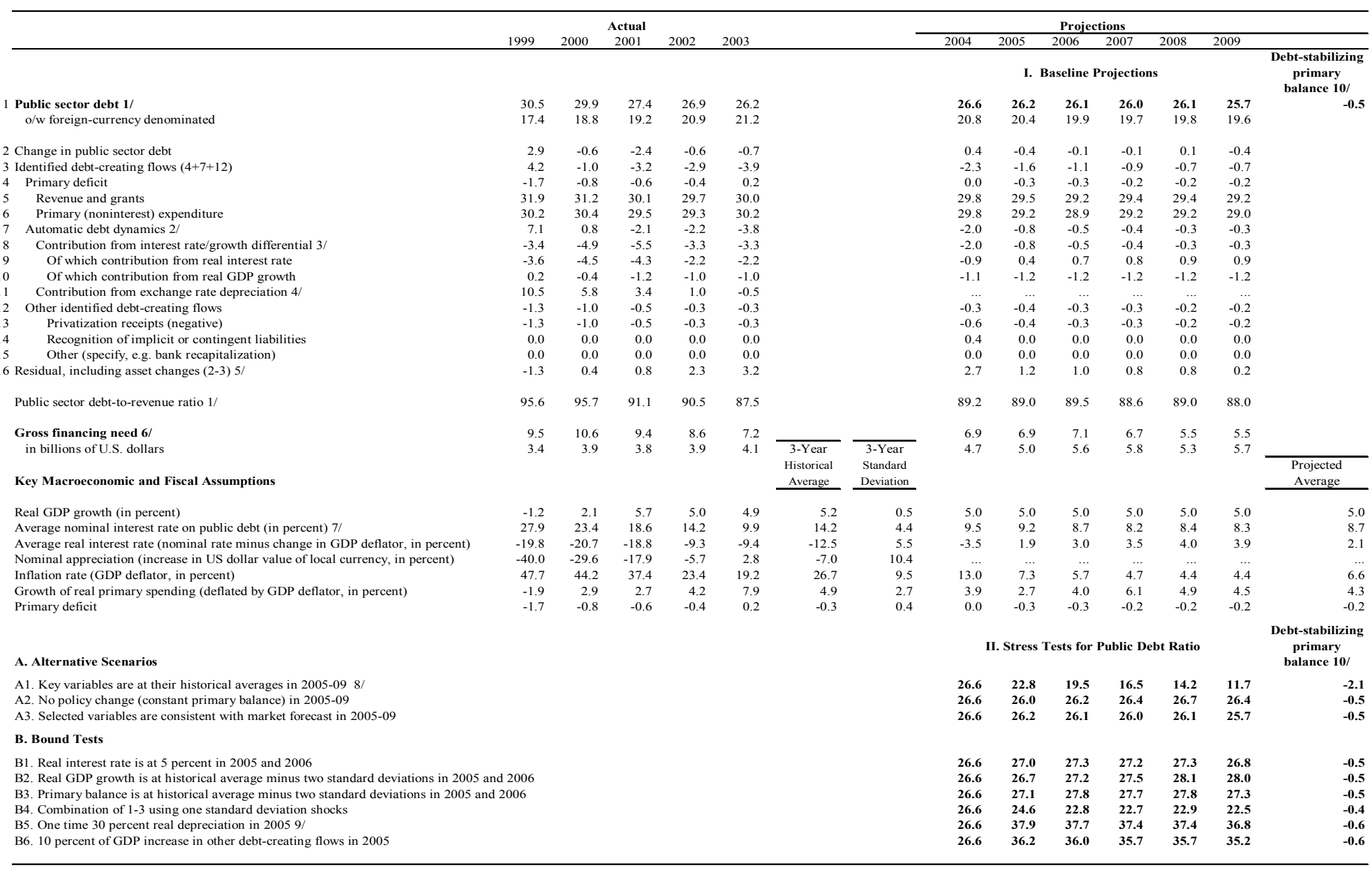

1/ Consolidated general government including public guarantees, gross debt.

2/ Derived as $[(\mathrm{r}-\pi(1+\mathrm{g})-\mathrm{g}+\alpha \varepsilon(1+\mathrm{r})] /(1+\mathrm{g}+\pi+\mathrm{g} \pi))$ times previous period debt ratio, with $\mathrm{r}=$ interest rate; $\pi=$ growth rate of GDP deflator; $\mathrm{g}=$ real GDP growth rate; $\alpha=$ share of foreign-currency

$\mathrm{r}-\pi(1+\mathrm{g})$ and the real growth contribution as $-\mathrm{g}$.

5/ For projections, this line includes exchange rate changes.

6/ Defined as public sector deficit, plus amortization of medium and long-term public sector debt, plus short-term debt at end of previous period.

Derived as nominal intest oxpend are divided by previous period debt stock.

(

10/ Assumes that key variables (real GDP growth, real interest rate, and primary balance) remain at the level in percent of GDP/growth rate of the last projection year. 
Table 18. Romania: Public Sector Debt Sustainability Framework— Gross Public Sector Financing Need, 1999-2009

(In percent of GDP, unless otherwise indicated)

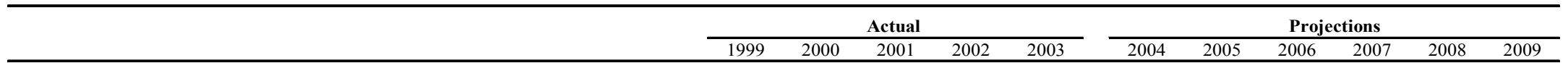

I. Baseline Projections

\section{Gross financing need 1/}

in billions of U.S. dollars

$\begin{array}{rrrrrrrrrrr}9.5 & 10.6 & 9.4 & 8.6 & 7.2 & 6.9 & 6.9 & 7.1 & 6.7 & 5.5 & 5.5 \\ 3.4 & 3.9 & 3.8 & 3.9 & 4.1 & 4.7 & 5.0 & 5.6 & 5.8 & 5.3 & 5.7\end{array}$

\section{Gross financing need 2/}

II. Stress Tests

A. Alternative Scenarios

A1. Key variables are at their historical averages in 2005-09 3/

A2. No policy change (constant primary balance) in 2005-09

A3. Selected variables are consistent with market forecast in 2005-09

$\begin{array}{rrrrrr}6.9 & 3.2 & 2.5 & 1.7 & 0.7 & 0.5 \\ 6.9 & 7.1 & 7.3 & 6.9 & 5.8 & 5.8 \\ 6.9 & 6.9 & 7.1 & 6.7 & 5.5 & 5.5 \\ & & & & & \\ 6.9 & 7.7 & 7.8 & 7.0 & 5.8 & 5.7 \\ 6.9 & 7.2 & 7.7 & 7.5 & 6.3 & 6.4 \\ 6.9 & 7.9 & 8.2 & 7.1 & 5.9 & 5.8 \\ 6.9 & 5.1 & 4.6 & 5.8 & 4.8 & 4.8 \\ 6.9 & 8.1 & 10.3 & 9.7 & 8.0 & 7.9 \\ 6.9 & 8.0 & 9.8 & 9.3 & 7.6 & 7.6\end{array}$

B1. Real interest rate is at historical average plus two standard deviations in 2005 and 2006

B2. Real GDP growth is at historical average minus two standard deviations in 2005 and 2006

B3. Primary balance is at historical average minus two standard deviations in 2005 and 2006

B4. Combination of 2-4 using one standard deviation shocks

B5. One time 30 percent real depreciation in 2005

B6. 10 percent of GDP increase in other debt-creating flows in 2005

\section{Gross financing need in billions of U.S. dollars 2/}

\section{A. Alternative Scenarios}

A1. Key variables are at their historical averages in 2005-09 3/

A2. No policy change (constant primary balance) in 2005-09

A3. Selected variables are consistent with market forecast in 2005-09

$\begin{array}{llllll}4.7 & 2.4 & 2.0 & 1.5 & 0.7 & 0.6 \\ 4.6 & 5.1 & 5.8 & 6.0 & 5.6 & 6.1\end{array}$

\section{B. Bound Test}

B1. Real interest rate is at 5 percent in 2005 and 2006

B2. Real GDP growth is at historical average minus two standard deviations in 2005 and 2006

B3. Primary balance is at historical average minus two standard deviations in 2005 and 2006

B4. Combination of 1-3 using one standard deviation shocks

B5. One time 30 percent real depreciation in 20054

B6. 10 percent of GDP increase in other debt-creating flows in 2005

1/ Defined as public sector deficit, plus amortization of medium and long-term public sector debt, plus short-term debt at end of previous period.

2/ Gross financing under the stress test scenarios is derived by assuming the same ratio of short-term to total debt as in the baseline scenario and the same average maturity on medium- and long

term debt. Interest expenditures are derived by applying the respective interest rate to the previous period debt stock under each alternative scenario.

3/ The key variables include real GDP growth; real interest rate; and primary balance in percent of GDP.

4/ Real depreciation is defined as nominal depreciation (measured by percentage fall in dollar value of local currency) minus domestic inflation (based on GDP deflator) 
Managing Director

International Monetary Fund

Washington, D.C. 20431

Dear Mr. de Rato:

The attached Memorandum on Economic and Financial Policies (MEFP) specifies understandings reached with staff in discussions on a 24-month program supported by a StandBy Arrangement (SBA) with access of SDR 250 million (24.27 percent of quota), which we intend to treat as precautionary.

Over the course of the previous program (2001-2003), macroeconomic imbalances in our economy were reduced, structural reforms advanced, and GDP growth and investment rose fast. We brought inflation from 40 percent in early 2001 to 14 percent at end-2003, in line with the program targets. After a sharp reduction in 2002, the current account deficit widened in 2003 as a result of rapid credit and wage growth, and FDI-related imports. Privatization and structural reforms advanced, albeit slower than targeted.

Our main macroeconomic objectives are to consolidate stabilization and gradually lower inflation to mid-single digits by 2006, keep the current account deficit below $5 \frac{1}{2}$ percent of GDP and maintain reserve coverage at $3 \frac{1}{2}$ months of imports. Moreover, in line with our strong commitment to accede to the European Union in 2007, we intend to decisively improve governance and the business climate and complete the privatization agenda. The MEFP specifies measures, some of which already implemented, to achieve these objectives. Based on this, we are requesting the approval of the arrangement.

The Government believes that the policies set forth in the attached MEFP are adequate to achieve the objectives of its program and ensure sustainable macroeconomic developments in 2004-2006, but it will take any further measures that may become appropriate for this purpose. Romania will consult with the Fund on the adoption of these measures, and in advance of revisions to the policies contained in the MEFP, in accordance with the Fund's policies on such consultation.

Yours sincerely,

$/ \mathrm{s} /$

Adrian Nastase

Prime Minister

Government of Romania /s/

Mugur Isarescu

Governor

National Bank of Romania

Attachment 


\section{Memorandum on Economic ANd Financial Policies for 2004-06}

\section{INTRODUCTION}

1. This memorandum describes the main economic and financial objectives and policies of the government and the National Bank of Romania (NBR) for the period 2004-06. The program reflects our strong commitment to consolidate and advance the macroeconomic stabilization achieved under the previous Stand-By Arrangement (SBA) and accelerate structural reforms with a view to establishing sustainable rapid growth and ensuring EU accession in 2007. Following the implementation of the comprehensive reform agenda and ambitious macroeconomic objectives under the program, we expect that Romania will no longer need Fund arrangements.

\section{BACKGROUND}

2. With prudent fiscal and monetary policies, we achieved far-reaching progress in macroeconomic stabilization in 2001-03, and established the basis for robust economic growth. Fiscal tightening, reduction in losses in state-owned enterprises (SOEs), and prudent monetary policies reduced inflation from 40 percent in early 2001 to 12.5 percent in April 2004. Moreover, disinflation was achieved without adverse effects on GDP growth, which at about 5 percent during the last three years was among the highest in the region. Investment picked up strongly, with the fixed investment rate increasing from 18.9 percent of GDP in 2000 to $22 \frac{1}{2}$ percent in 2003. After a long decline, the number of salaried workers increased by $1 / 3$ percent in 2003 . Our external position strengthened remarkably, with official reserves increasing from $2 \frac{1}{2}$ months of prospective imports at end-2000 to about $3 \frac{1}{4}$ months at end-2003. Ratings for our sovereign bonds have been raised several times, while spreads have declined rapidly.

3. However, extremely rapid credit expansion, and to a lesser extent wage growth, led to a widening of the current account deficit in 2003. On the back of improved confidence, banking credit to the private sector surged, growing at over 50 percent in real terms in 2003, led by consumer and mortgage loans. The resulting strengthening in domestic demand, which also reflected the spillover of the minimum wage increase in January 2003, pushed up imports, while the protracted economic weakness in the euro area slowed our exports. These developments widened the current account deficit from 3.4 percent of GDP in 2002 to 5.9 percent of GDP in 2003, exceeding our target by about 1.1 percent of GDP.

4. Following overperformance in reducing inflation in the first half of 2003, disinflation stalled in the second half of 2003. The slowdown reflected both the effects of the minimum wage adjustment, strong domestic demand and energy price increases. Nevertheless, we largely met our annual target of 14 percent by December, and disinflation resumed in early 2004.

5. Fiscal policy in $\mathbf{2 0 0 3}$ stayed on track. The general government deficit came out 0.3 percent of GDP better than targeted. The SOEs' S-I balance improved by 0.1 percent of 
GDP, as the increase in arrears to the budget was lower than in 2002. We succeeded in keeping SOE wages within the approved company budgets. Moreover, the collection rates of the main utilities have stayed in the 95-98 percent range, except for heating.

\section{Monetary policy has been tightened and bank supervision strengthened. In} response to the temporarily slowing disinflation and rapid credit growth, the NBR raised the policy interest rate by cumulative 300 basis points since August 2003 and introduced prudential norms to tighten household eligibility for consumer and mortgage loans. In particular, the NBR limited the monthly payment-to-net-income ratio to 30 percent, imposed mandatory 25 percent downpayment or a co-signer/insurance for consumer loans and a cosigner, insurance or collateral for personal loans. The NBR and the Security Supervision Commission lowered the maximum payment-to-net income ratio to 35 percent for mortgage credit and introduced a maximum loan-to-value ratio of 75 percent. All these measures became effective on February 1, 2004. Similarly, the Insurance Supervision Commission issued a regulation limiting insurance companies' retained exposure to bank loans. The commercial banks are in the process of establishing a credit bureau to monitor consumer and business credit, expected to be operational in Q4 of 2004. We have also postponed the liberalization of leu deposits of nonresidents in local banks, scheduled for January 2004. Despite the rapid growth of credit so far, we consider the resulting prudential risks to be manageable as banks are well-capitalized and liquid. Following the introduction of a new regulation on loan classification in early 2003, provisioning against credit risk is in our view adequate, which was also confirmed by the FSAP conducted in 2003.

\section{In 2003 and early 2004, we have made substantial progress in privatization and} improving the business climate. Since the beginning of 2003, the Privatization Agency sold 23 large loss-making SOEs with over 70,000 employees. In about 70 largest SOEs monitored under the program, employment was reduced by $7 \frac{1}{2}$ percent, or over 34,000 thousand employees, with particularly large cuts achieved in the railway sector. We have completed negotiations on the investment of the IFC and EBRD in the largest bank, BCR, and the settlement is expected in early June. Moreover, we have received three binding bids for the privatization of the largest company Petrom and have selected the winning bidder. Delays have, however, been experienced in the privatization of the electricity and gas distributors. To improve the business climate, we have approved an anticorruption plan and established an anticorruption public prosecution office in 2003.

8. Energy sector reforms advanced significantly in 2001-03. Sharp increases in energy prices have reduced energy sector losses substantially. We have brought electricity prices close to cost-recovery levels, sharply increased heating prices, and raised domestic gas prices, though the latter remain substantially below import parity. Our fight against the nonpayment culture has been effective in the gas and electricity sectors, but more efforts are needed in the heating sector. 


\section{EConomic And Financial Policies}

\section{A. Objectives and Strategy}

9. The main objectives of our 2004-06 program are to sustain and advance macroeconomic stabilization and accelerate structural reforms. Our key macroeconomic objectives are: (i) to reduce inflation to 9 percent by end-2004, 6 percent by end-2005, and 5 percent by end-2006; (ii) to contain the external current account deficit to below $5 \frac{1}{2}$ percent of GDP; and (iii) to maintain reserve cover at a comfortable level of $3 \frac{1}{2}$ months of prospective imports. We expect that our economy will grow at an average annual rate of 5 percent during 2004-06, helping to reduce the GDP per capita gap relative to the EU. Stabilizing inflation at single digits for the first time in Romania's transition history would in our view be a powerful signal that sound economic policies have taken hold. As about 2/3 of the current account deficit is projected to be covered by non-debt creating flows, we view its projected level as sustainable. With the private sector S-I balance expected to decline further, all the improvement in the external current account deficit will have to come from the public sector, the budget and S-I balances of SOEs. External risks remain manageable in light of our progress in structural reforms, low external and public debt-to-GDP ratios, and the favorable term structure of our debt.

\section{The main elements of our macroeconomic policy package in 2004 will be as}

follows: The S-I balance of the broad public sector will be improved by about $1 \frac{1 / 4}{4}$ percentage point of GDP, which will be achieved by tightening our 2004 budget target, a modest nominal increase in the minimum wage, a prudent wage program for SOEs, and further reforms in the energy, railway and mining sectors. Monetary policy will be appropriately tight and, together with prudential measures, should slow credit growth to facilitate disinflation and contain the current account deficit.

\section{Structural reforms in 2004-2006 will aim at completing the privatization} agenda, strengthening financial discipline and tax compliance in SOEs and private companies alike, and decisively improving governance and the business climate. The program will provide a strong impetus to privatization in the energy sector, including the largest company in the country, Petrom, the entire gas distribution sector, and many electricity generation and distribution companies. In this context, the reform of the pricing mechanism for natural gas with a view to raise domestic producer prices to import parity by January 2007 gains in urgency and importance. The program will also facilitate the privatization or liquidation of the remaining 19 large loss-making SOEs under the Privatization Agency. Decisive measures will be taken against private tax nonpayers, while the financial performance of the state-owned nonpayers - concentrated primarily in the railway and mining sector-will be improved by strong and credible loss-reduction programs. Other measures will aim at improvements in the important areas of governance, competition, and the business climate. 


\section{B. Fiscal Policy}

\section{Fiscal policy in $\mathbf{2 0 0 4}$ will support disinflation and help contain the external} current account deficit, while creating scope for further private sector investment. In particular:

- In May 2004, we will publicly announce the decision to tighten the general government deficit target to 2.1 percent of GDP, with a view to assuring markets that we are taking appropriate measures to contain the current account deficit. We will approve a supplementary budget in line with this revised deficit target by July 20, 2004 (structural PC). Owing to much stronger revenue performance than assumed at the time of the 2004 budget approval, we will be able to achieve this objective by preserving the overall budgeted expenditure envelope, while compensating somewhat higher local government spending with cuts at the central government level. If revenue comes out stronger than consistent with the deficit target of 2.1 percent of GDP, we will not increase the expenditure envelope envisaged in the program, and will use all the additional revenue for reducing the deficit. Expenditures for all motorway projects, including projects on the basis of public-private partnerships and projects financed with off-budget guarantees, will be accommodated within the new budget deficit ceiling, unless a different treatment would be appropriate in line with the recommendations of the FAD technical assistance. Privatization proceeds will continue to be treated as a financing item in fiscal accounts (Technical Memorandum of Understanding (TMU), section III).

- We will implement measures to improve the saving-investment balances of the SOEs to facilitate an overall adjustment in the broad public sector deficit of 11/4 percent of GDP. The measures are described in paragraphs $21-26$ and 32-33. To help us ensure that the fiscal objective for the broad public sector is met, we will establish monthly monitoring of the public sector borrowing requirement (PSBR), which will be a quantitative benchmark in 2004 . We will make every effort to improve the reliability of these data with a view to convert this benchmark into a quantitative PC starting with the first quarter of 2005.

\section{We stand ready to tighten fiscal policy further if our current account or} disinflation targets are at risk. We expect that the targeted reduction in the budget deficit and the measures to improve the saving-investment balance of SOEs are sufficient to contain the recent strong growth in domestic demand and will result in an improvement in the external current account deficit in the first half of 2004. Should this not be the case, we are firmly committed to implementing corrective measures, including tightening fiscal policy further. Supplementary budgets and possible revisions of expenditure ceilings will be discussed in the context of quarterly reviews under the arrangement.

14. On tax policy, we have decided to give priority to a further reduction in social security contribution rates. Following the reduction of payroll taxes by 3 percentage points 
in 2002 and 5 percentage points in 2003, we have cut the employers' pension fund contribution rate by 2.5 percentage points and the employers' unemployment fund contribution rate by 0.5 percentage points on January 1,2004 . The eligibility for the reduced VAT rate will be limited to pharmaceutical products, hotel accommodation, newspaper distribution, and a small group of previously VAT-exempted products. We will refrain from reducing profit tax and personal income tax rates in 2004, as they are comparable with rates in other EU accession countries and we cannot afford further loss of revenue. We have also decided to refrain from introducing interest deductibility for mortgage loans. We will not modify tax legislation in 2004 and will consult with Fund staff on any amendments that we may envisage for 2005. Moreover, we will refrain from introducing tax holidays or any other new distortionary tax incentives or postponing the discontinuation of expiring ones (continuous structural benchmark).

\section{The implementation of the comprehensive tax administration reform will} continue. On January 1, 2004 we established the National Agency for Fiscal Administration (NAFA) under the Ministry of Public Finance and transferred the collection of social security contributions to the new agency. The modernization of our revenue administration will now focus on operations, systems and processes, and human resources. We intend to create a function-based structure with strong supervision from headquarters, which will control automated business processes and implement risk-based compliance programs. In line with the recommendations of the Fund's Fiscal Affairs Department (FAD), we have established project structures for the recommended reforms. Detailed plans for the achievement of the main objectives will be approved by end-June 2004. In July 2004, we will begin discussions on potential funding with donor organizations. Moreover, to ensure that all revenue collection functions are integrated, the government will approve an act that would subordinate, as of January 1, 2005, customs administration and the Financial Guard to the Minister of Public Finance (structural performance criterion).

\section{We remain strongly committed to keeping budgetary sector wages and pensions} within the limits of the 2004 budget. We have limited the increase in budget sector wages in 2004 to 6 percent in nominal terms on January 1, 2004 and another 6 percent on October 1, 2004 by approving Government Ordinance 123/2003. The annual bonus for 2003, paid in early 2004, was limited to the equivalent of one month's salary in 2003, and we will apply this principle accordingly for the 2004 bonus to be paid in 2005. In the SOEs sector, to avoid that the use of SOE profits for wage bonuses undermine our wage program, we will amend by end-July 2004 Government Ordinance 64/2001 to limit the use of profits for this purpose to one monthly average base wage. Taking into account the need to consolidate the pension fund, we are determined not to exceed the scheduled increase in pensions and the pension expenditures in the 2004 budget. To ensure the medium-term sustainability of the public pension system, we will agree with the World Bank in the context of the Programmatic Adjustment Loan operation to accelerate the increase in the retirement age and to start the equalization of the retirement age for men and women starting with July 1, 2005. We will not decide on any new pension "recorrelation" after completing the current "recorrelation" by mid-2004 without prior consultations with Fund and World Bank staff. 


\section{We will step up the fight against expenditure arrears of the budget. We will} ensure that the local authorities do not incur arrears, including with respect to subsidies to district heating companies. Moreover, the unpaid amount of the arrears to health sector suppliers accumulated in 2002, identified in protocols agreed with the supplier organizations in amount of lei 3,644 billion, will be repaid by end-September 2004 (structural performance criterion). To avoid the recurrence of arrears, we have approved in February 2004 legislation strengthening the procurement legislation for medical supplies. Based on World Bank recommendations to improve the efficiency of the hospital system, we will approve by end-June 2004 a strategy for the short-, medium-, and long-term rationalization of the entire health sector.

18. We will move decisively against large tax nonpayers and tax evasion. In addition to our efforts to ensure full tax payment by SOEs, we will vigorously address the issue of private sector arrears to the budget. In 2002-03, the largest private sector arrears to the general government were accumulated by three refineries. Bankruptcy procedures against one of these companies were initiated on January 22, 2004. As a prior action, on March 31, 2004 the Ministry of Finance initiated bankruptcy against the second largest refinery. Subsequently, the Ministry initiated bankruptcy procedures against 4 other private companies with the largest flow of arrears to the budget, as well as a large number of other companies. The largest private refinery has improved its tax compliance after the rescheduling of its stock of arrears. However, we will revoke the rescheduling if the company fails to pay taxes and service the rescheduled stock of arrears on time and in full. Reduction in arrears of the 452 largest private debtors to the state budget and the social security funds will be a quantitative performance criterion under the program (TMU, section $\mathrm{V}$ ), while the reduction in SOE arrears to the general government will be an indicative target (TMU, section VI). Moreover, we will continue posting a list of the top 549 debtors to the state budget on the internet and update this list every quarter, while also including, as of January 1, 2004, arrears to the four social security funds (updated monthly data will be shared with Fund staff). We will step up the fight against tax evasion. For this purpose, we will approve by end-June 2004 a comprehensive plan to (a) eliminate the illegal trade in petroleum products and cigarettes, areas where corruption is perceived to be pervasive; and (b) to fight corruption in the customs administration. This plan will be prepared in close consultation with business associations and other stakeholders. In addition, we will request technical assistance from the Fund to review by end-June 2004 the legislation on prevention, discovery, control, and sanction of tax fraud. Moreover, decisions by the Competition Council on state aid, including on tax arrears rescheduling, will be made public on the internet together with the explanation.

19. In financing the $\mathbf{2 0 0 4}$ budget deficit, we will give priority to domestic borrowing, to limit supply pressures for private sector credit. Taking into account large expected privatization receipts from abroad, we will limit our Eurobond issuance to not more than $€ 600$ million in 2004, €425 million of which will not be spent in the current year (the number is subject to revision in the first review). Domestic financing will aim at extending the maturity of lei-denominated securities. 
20. We will contain the issuance of all external off-budget guarantees in 2004 to 2.3 percent of GDP (US\$1.5 billion) compared to 2.2 percent in 2003 , to ensure that the target for the overall fiscal stance of the broad public sector is met. The ceiling will apply to off-budget guarantees for fuels, loans from multilateral and official creditors, and other off-budget guarantees. Within the ceiling, we will give priority to projects for modernizing the energy and railway sectors. We will limit the issuance of domestic guarantees to a maximum of the lei equivalent of $€ 20$ million (excluding guarantees for bridge loans to local authorities for temporary financing of projects under the SAPARD 21 program), with guarantees limited to cases approved by the Competition Council. In addition, by end-September 2004, we will amend Emergency Ordinance 146/2002 (approved by Law 201/2003) to preclude any further loans from the treasury to state-owned enterprises.

\section{Wage Policy}

21. To protect the competitiveness of our economy, we only modestly increased the minimum wage in 2004. We approved a government decision, stipulating an increase of 12 percent in the statutory minimum wage on January 1, 2004, to lei 2.8 million, a level that will remain unchanged until end-2004 (continuous structural PC). All government officials attending the negotiations on the national collective contract will seek to ensure that the minimum wage in this contract does not significantly deviate from the statutory minimum wage. Moreover, the government will instruct the representatives of the state-owned companies (a) not to accept a minimum wage different from the statutory minimum wage; and (b) to request the employers associations which they are affiliated with to refuse accepting any such deviation. The government will also ensure that such a national contract or other collective contracts will in no way affect the SOEs wage program stipulated in the following paragraph, while it will use persuasion to moderate wage settlements in the private sector. The appropriate minimum wage increase in 2005 will be discussed with Fund staff in the context of the first review of the program.

\section{Our SOE wage policy in 2004 aims at improving the financial performance of} 72 large monitored companies by about $1 / 2$ percent of GDP. To ensure prudent wage policy in the SOE sector, we will rectify the budgets of the monitored companies by end-April, 2004, limiting the wage bill growth to 7 percent (prior action). With the scheduled reduction of employment by 19,000 positions, this implies an average gross wage growth of about 11 percent in nominal terms, below the projected average inflation. To strengthen the credibility of our wage bill target, the ministries will block payments equivalent to 4 percent of the quarterly wage bill in monitored SOEs until the last month of the quarter and will release it only after it has become clear that the respective target will be reached.

\section{Energy Sector Reforms}

23. To reduce our growing dependency on gas imports, we will continue increasing domestic producer prices with a view to reaching import parity level by January 2007. On March 15, we announced a schedule for gas price increases (prior action). For 2004, the schedule specified that the end-user gas prices would be increased every quarter by 5 percent 
in lei terms (prior action for April 1 and July 1, structural PCs thereafter). For 2005-2007 the schedule specified the producer price for the regulated market, as envisaged in the ordinance approved on December 18, 2003. While under the current system domestic producers effectively receive the residual after the variable import costs of imports are covered (in addition to the costs of transport, storage, and distribution), under the new system the gas distributors and end-users will have to absorb variable import costs and the gradual increase in producer prices to import parity. The first yearly increase of the end-user regulated price according to the new pricing system will be effective as of January 1, 2005, when domestic producer prices for the regulated market will be increased by at least US $\$ 25 / \mathrm{tcm}$, starting from the estimated 2004 level of US\$60/tcm (structural PC; the exchange rate used for converting the U.S. dollar increase into lei prices is specified in the TMU, section VII). The following adjustment of the same size will be effective as of January 1, 2006.

\section{We will continue adjusting the electricity and heating prices to cost recovery}

levels. End-user and Termoelectrica electricity and heating prices will be adjusted to costrecovery levels (including return on capital for distribution companies) every semester on January 1 and July 1 (a prior action for July 1, 2004 and structural performance criteria thereafter). The regulatory agency will produce reports on these adjustments and share them with the staff (continuous structural benchmark). Moreover, in cooperation with the World Bank, in March 2004 we reviewed the structure of electricity prices, which has confirmed that the final-user distribution prices are consistent with the full payment to producers and will fully cover the distributors' margins once the Bank's proposal for the July 2004 price adjustment is implemented. The World Bank has also reviewed the electricity producer price for thermo-producers, concluded that they are at an appropriate level, and recommended that the government approve a plan to deal with the thermo-producers' high-cost units ("stranded assets"). The Bank has also recommended that the July 1, 2004 adjustment include a margin required to provide a return on capital at least equal to the cost of debt in the distribution sector, which is an important step for the commercialization and privatization of distribution companies. We will implement these recommendations, which will require a final-user price adjustment of about 6-7 percent. In the context of the first review, we will discuss with staff further steps in energy sector reform, including the elimination of the uniform retail tariff policy allowing the end-user price differentiation across regions, the elimination of the national development tax, and the steps for increasing hydro-power producer prices with a view to fully liberalizing the market by 2007 .

\section{We will approve a reform strategy for the district heating system in close} cooperation with the World Bank (prior action). This strategy will envisage a switch to heating contracts or conventions with individual households, the installation of thermostatic valves and heat meters, and the introduction of a split-tariff structure. In addition, we will review social assistance for households and modify it if necessary. A timetable for introducing these measures was prepared in April 2004. We will approve an Emergency Ordinance by June 10, 2004, terminating all subsidies and delivery of fuel by state-owned companies to 15 inefficient heating plants (prior action) and we are committed not to resume such subsidies or deliveries, and hence encourage the local administrations to stop production and decide on the closure of the plants. By end-June, we will ensure that, for each of these 
plants, either the local administration has taken such a decision, or bankruptcy procedures have been started by the government (in case of debts to the budget) or by a state-owned fuel supplier (in case of debts to the fuel suppliers) (prior action). We will share the documents proving that these decisions were made with the Fund and World Bank staff. In addition, we together with the local administrations will take the necessary measures to assist the few remaining connected households to switch to individual heating systems. Termoelectrica's producer heating price will be raised by 12 percent as of July 1, 2004. The National Reference Price for heating will be raised by 12 percent as of August 1, 2004 (structural PC). The respective Government Decision will be approved by mid-July 2004. By end-September, we will prepare an analysis outlining the necessary steps for the elimination of the current system of producer subsidies by enhancing the existing targeted household support for heating and thus abolishing the National Reference Price.

\section{We will continue our efforts to eliminate the nonpayment of electricity and gas} bills by strict enforcement of the disconnection deadlines for electricity and gas payments. However, in 2004, the budget will continue to assume payments of energy bills for a few large loss-makers (the list of eligible SOEs will be approved through a Government Decision by end-July 2004), the disconnection of which would be socially disruptive. We will also intensify our efforts to improve collections from households. For that purpose, we will enforce seizure of assets of nonpayers through the judiciary system, as specified in Government Ordinance 85/2001 and Government Decision 400/2003. The largest industrial nonpayers to the four utilities will stay disconnected or on minimum supply until full payments for all bills from December 2002 onwards have been received by the utilities, while the bills for companies on minimum supply will be paid by the government (continuous structural benchmark).

\section{E. Privatization, Liquidation, and Restructuring}

27. The successful privatization of Petrom is our highest priority. We have eliminated some restrictions and uncertainties that could have adversely affected the success of the privatization. Specifically, as a prior action in March 2004, we decided that: (a) the entire amount of arrears to the general consolidated budget in litigation would be cancelled at the time of the share transfer; (b) the government would assume responsibility for environmental indemnities; and (c) there would not be any penalties for post-privatization deviations from employment levels included in the investors' business plan. Moreover, we subsequently clarified, by a letter to short-listed investors, that the government would assume environmental liabilities associated with abandoned wells, and limit restrictions on the restructuring of the company, including the sale of core assets, to at most four years, while also indicating that we would agree with the divestment of one refinery and the petrochemical complex even before that deadline. As indicated in paragraph 23, the schedule for gas price adjustments was announced on March 15, 2004. All these decisions have increased the value of the company and created conditions for successful privatization.

28. We aim to achieve substantial progress in the privatization of utilities, building on recommendations from the World Bank. In close consultation with the World Bank, 
we will accelerate preparations for the privatization of the two gas distributors by inviting binding bids by July 20, 2004 (prior action). We have received one binding offer for the privatization of two electricity distribution companies in March, for which negotiations are ongoing. We will not offer special tax incentives to investors or preferential treatment in subsequent privatizations. If this fails, we will either re-launch the privatization for these two companies, or select two others for privatization in 2004, in addition to the two in the pipeline. By end-September 2004, we will prepare a privatization strategy for ElectricaMuntenia Sud, with the aim of inviting binding offers by end-March 2005. We will start discussions with the World Bank on the privatization of Romgaz, and power generators Rovinari and Turceni.

\section{We will either privatize or liquidate the remaining 19 large SOEs under AVAS} by end-September 2004. In addition to the company already privatized in Q1 of 2004, we initiated bankruptcy for five large SOEs (companies with more than 1,000 employees), including Republica, CUG and Turnu (prior action). Thereafter, we will either privatize or liquidate six such companies in Q2 and another six in Q3 (structural benchmarks), leaving two for Q4 of 2004. To improve the prospects for successful privatization, we implemented an employment reduction program and eliminated 15,000 positions in March, including 2,600 layoffs in Roman (prior action). Moreover, as part of the approved 2004 wage program a wage-freeze will be imposed in all companies under AVAS that incurred losses (after taxes) in 2003 (prior action); those that have not incurred losses can benefit from a wage increase by up to 9 percent. For companies with particularly weak financial results, in March the Privatization Agency and the shareholder meetings decided on the voluntary liquidation of 15 unviable SOEs (including Republica, CUG, and Turnu) and is now appointing liquidators. We will also establish quarterly targets for the privatization or liquidation of smaller companies.

\section{On the privatization of Roman, we are determined to prevent any parts of the} company from returning to state ownership. As part of the privatization deal, 2,600 layoffs in the remaining units of Roman were implemented by April 15, 2004 (prior action). Should any parts not pay energy bills and taxes on time, we will immediately start foreclosure proceedings (continuous structural benchmark).

\section{We will review the privatization of the National Tobacco Company. We} concluded a contract with an internationally reputable accounting firm to carry out due diligence of the privatization contract, which will be finalized by end-June. We will re-tender the National Tobacco Company by end-June 2004 if the tender process is found to have been deficient.

32. Our efforts to restructure the railway sector will continue. Following the large layoffs and the privatization of 21 subsidiaries in the second half of 2003, we intend to close by end-June 2004 about 3,000 km of loss-making secondary lines ( 26 percent of the total network), if the respective segments are not taken over by investors in the form of concession contracts by June 15, 2004. We passed the corresponding government decision in January 2004. For the segments under subconcession contracts, we will not impose on the investors' 
obligations to maintain employment. Employees that are not taken over by the investors will be laid off by CFR by the date of the effectiveness of the concession contract but no later than end-June 2004. We will continue with reducing employment in the railway companies by 8,000 employees in January-September 2004. To improve the financial performance of railways, we raised the price of passengers' tickets by 6.3 percent on February 15 and will raise it by another 6 percent on July 15, 2004. We also increased the freight tariffs by 10 percent on March 1 and will raise it by another 10 percent on July 1, 2004. By July 1, 2004 we will complete the outsourcing of the CFR messenger service to a private company, which is expected to result in savings of about lei 200 billion. The 2004 budgets of the railway companies will be rectified to ensure that the remaining operating losses, as well as obligations to the utilities and the general government budget, are fully covered by the allotted budgetary subsidies. The railway companies will also continue with the privatization of four subsidiaries and the divestment of non-core assets.

33. We will implement an ambitious restructuring plan in the mining sector. We approved and published on May 28, 2004 a strategy for restructuring the mining sector in 2004-10, which was formulated in cooperation with the World Bank and in line with EU guidelines for environmental protection (prior action). The strategy set out detailed schedules for the mines to be privatized or closed, necessary employment reduction for each mine, as well as programs to address the social problems of the regions affected. It also includes the action plan and for 2004, with employment reduction plans and the list of mines to be closed, and a decision on 30 mines to be closed by June 30, 2004. In line with the strategy, 4,000 mining sector employees were made redundant by end-June 2004 (prior action), and another 4,000 will be made redundant by September 30, 2004 (structural PC). The 2004 budgets of the mining companies will be rectified to ensure that the remaining operating losses, as well as obligations to the utilities and the general government budget, are fully covered by the allotted budgetary subsidies.

\section{As part of our plans to improve the overall efficiency of our medium-term} expenditure plans for motorways, we are working with the World Bank to assess the overall affordability of the program. Prior to the finalization of motorway contracts currently under negotiation, we will seek the World Bank assistance on the following matters:

- A report of an advisor, financed by the World Bank, assessing the unit prices and financial arrangements associated with the Bors-Brasov motorway project;

- We asked the World Bank to prepare by end-July 2004, in consultation with the EBRD, a study assessing the priorities and the best routing of motorway construction. This study will also address the overall affordability and risk sharing associated with the PPP projects planned for the Brasov-Bucharest motorway, and the options for their re-tendering;

- A review, prepared in consultation with EC and other stakeholders, of the implementation of the procurement legislation, including the relevant norms, used 
for awarding large infrastructure projects and guidelines for awarding such contracts in the future.

- $\quad$ Following the preparation of the above reports, we will consult with Fund staff on the fiscal sustainability of the overall motorway program, including possible re-tendering, rerouting and phasing of the motorway program, before proceeding with the finalization of the existing projects under preparation.

- We will limit expenditures for motorway construction (including expenditures under PPP contracts, the Bechtel project, and projects financed with off-budget guarantees) to $€ 260$ million in 2004.

35. Our efforts to complete the privatization in the banking sector will continue. In April, we decided the timetable for the privatization of CEC, the State Savings Bank, with a view to complete it in 2005. Furthermore, we will announce a tender for a privatization advisor for the bank by end-May 2004. We will also finalize settlement for the EBRD's and the IFC's purchase of a share package in BCR by end-June, 2004 (prior action).

\section{We will implement several measures to fully improve transparency and}

accountability in the enterprise sector: (i) the government will decide by end-March 2004 (prior action) that all the 72 monitored SOEs publish on the websites of the responsible lineministries their independently audited annual earnings statements, starting with the accounts for 2003; in the same vein, we will also publish their (unaudited) quarterly financial results on these websites; (ii) we will continue publishing on the internet regularly reports on state aid, including subsidies in the form of arrears; and (iii) the internationally accepted accounting standards will be fully mandatory for all economic agents above a certain size in 2005 .

\section{F. Monetary Policy and Banking Issues}

\section{The NBR will continue to focus on lowering inflation to single digits while} managing monetary policy's transition to a new framework. The new NBR Law, to be passed by end-June 2004 (prior action), will ensure the independence of the NBR in accordance with the relevant EU acquis, as well as make price stability the Bank's primary monetary policy objective. This, together with our advances in forecasting inflation and elaborating transparency and accountability procedures, will provide the necessary legal, technical and institutional prerequisites for a gradual implementation of inflation targeting. The new regime will take into account that the exchange rate pass-through to prices still dominates interest rate changes in determining inflation developments.. With inflation firmly stabilizing in single digits and transmission from policy to market interest rates improving over time, the onus of policy action will gradually shift toward the interest rate.

38. In 2004, monetary policy will continue to apply the current framework. The NBR will continue to guide the exchange rate along a path consistent with the inflation objective and modest real appreciation against the new 75/25 euro/U.S. dollar basket, in line with the 
estimated Balassa-Samuelson effect. This policy combines substantial short-term exchange rate flexibility with inflation-stabilizing guidance over a longer horizon. Tight fiscal and wage policy, as outlined above, will facilitate improvement in the external current account, allowing the NBR to focus on disinflation. We will begin to gradually lower the policy interest rate after we are assured that disinflation and the current account are firmly on track. We will continue with the liberalization of non-resident leu deposits with local banks when the interest rate differential between domestic and world markets would not create opportunities for large and potentially destabilizing inflows.

\section{The NBR will continue to monitor credit growth and implement decisive measures to contain it as needed for both macroeconomic and prudential reasons.} Should the rapid credit growth not subside following the eligibility-tightening measures introduced in February, we will introduce mandatory reporting by banks and non-banks to the newly established credit bureau and consider further measures to contain credit growth, including by increasing the reserve requirements for sources of financing denominated in foreign currencies. As of September 1, 2004, the NBR's credit bureau will expand its data base on delinquent loans with loans below lei 200 million, not monitored hitherto. As insurance companies have insured more than half of banks' household credit portfolio, the insurance supervisory commission will monitor insurers' pricing and re-insurance of that risk. Furthermore, for consumer protection we will adopt a law requiring truthful disclosure of lending terms and risks by all suppliers of consumer credit.

\section{G. Governance Issues, Business Climate, and Labor Market}

\section{Our efforts to strengthen public administration, eliminate corruption and improve the business climate will continue in close cooperation with the $\mathrm{EU}$ and the World Bank.}

41. We are intensifying our efforts to improve the functioning of the judiciary. By June 30, 2004 we will obtain parliamentary approval of laws on judicial organization, on the statute of magistrates, and on the Superior Council of the Magistracy (SCM) as a single, coherent package (prior action) after full consultation with the EU Commission, the World Bank, and local stakeholders. The new laws will strengthen the role of the Superior Council of the Magistracy as guarantor of the independence of the judiciary. In particular, the new laws will establish the full authority of the Council with respect to the recruitment, training, and professional careers of judges and render decisions in disciplinary actions in the judiciary (most of these powers have so far been vested with the Ministry of Justice). Having eliminated the extraordinary appeal procedure by the Attorney General for civil cases, we submitted to parliament on April 1, 2004 legislation to eliminate it for all other cases (prior action). We will ensure approval of this legislation by July 20, 2004 (structural performance criterion). Moreover, in consultation with the World Bank, we will review the issue of excessive length of court procedures in civil and commercial cases, particularly in restitution and bankruptcy cases, and decide by October 1,2004 on the establishment of a monitoring system according to the law. 
42. In consultation with the World Bank we have strengthened the legislation on the declaration of assets by government and parliamentary officials and near relatives (in particular, valuation and disclosure requirements). The new legislation improves the transparency of the asset declaration form, includes some itemization of assets, expands coverage of the declaration to candidates running for office, and lowers reporting thresholds. The legislation was approved in May, 2004 (prior action). Furthermore, we will explore the option of establishing special offices in each ministry responsible for checking the declaration of assets of all persons involved in the decision-making process and reach a decision by end-June 2004 .

43. We will provide additional resources for the National Prosecutor's AntiCorruption Office (ANC) in 2004. In particular, we will increase the number of ANC-prosecutors (currently 95) by about 50 percent. The ANC will give a higher priority to the investigation and prosecution of grand corruption. Moreover, we will approve by endJanuary 2005 legislation amending Article 24, paragraph 2, of the Law on Ministerial Responsibilities (Law 115/1999), which granted immunity also to former members of the government.

44. In cooperation with the World Bank, we will evaluate the impact of the new Labor Code on the labor market and employment and amend it accordingly with a view to preserving labor market flexibility. The comprehensive overhaul of the labor code in early 2005 will address concerns of the stakeholders, among which is the concern about the wage guarantee fund, regulations on hiring and firing, and red tape The overhaul of the code will be agreed upon with the World Bank within the framework of the EU acquis, and be submitted to parliament by end-March 2005. The corresponding PC will be set at the time of the second or third review under the program.

\section{Program Monitoring}

45. The program will be monitored on the basis of the performance criteria and indicative targets as described below. The program will be reviewed by the IMF on a quarterly basis during the period of the SBA (June 2004-June 2006). In addition to the main financial performance indicators, the reviews will be devoted to assessing progress in implementing the structural elements of the program, in particular, those regarding energy price adjustments, wage discipline, the reduction in arrears, and steps to privatize the remaining large SOEs, including Petrom. Agreements on the 2005 and 2006 general government budget, minimum wage decisions and SOEs' wage and employment program will be conditions for completing a review.

46. The quantitative performance criteria are as follows: (i) quarterly ceilings on the net domestic assets of the NBR; (ii) quarterly floors on the net foreign assets of the NBR; (iii) quarterly ceilings on the deficit of the consolidated general government; (iv) quarterly ceilings on the cumulative nominal wage bill in the monitored state-owned enterprises;

(v) quarterly floors on collection rates of four utilities; (vi) quarterly ceilings on domestic 
guarantees by the general government under public debt law and other laws, excluding export promotion guarantees; (vii) quarterly ceilings on the contracting or guaranteeing by the government of nonconcessional external debt; (viii) quarterly ceilings on the arrears of the 452 largest private debtors to the state budget and the four social security funds, and (ix) a continuous performance criterion of no accumulation of external payments arrears will also apply.

47. The indicative targets under the program are as follows: (i) quarterly ceilings on the total financing of the public sector; (ii) quarterly ceilings on arrears of monitored stateowned enterprises to the consolidated general government; (iii) quarterly ceilings on the exposure of commercial banks to SOEs; (iv) quarterly floors on collection rates for electricity and heating for Termoelectrica and its externalized units; and (v) separate quarterly floors on the collection rates of the gas distributors Distrigaz Nord and Distrigaz Sud. The second review will explore the feasibility of converting the ceiling on the total financing of the public sector into a performance criterion.

48. All quantitative performance criteria are specified in Table 1; the list of prior actions, structural performance criteria, and benchmarks are specified in Table 2. The main definitions appear in the TMU. 
Table 1. Romania: Quantitative Performance Criteria and Indicative Targets for 2004 1/

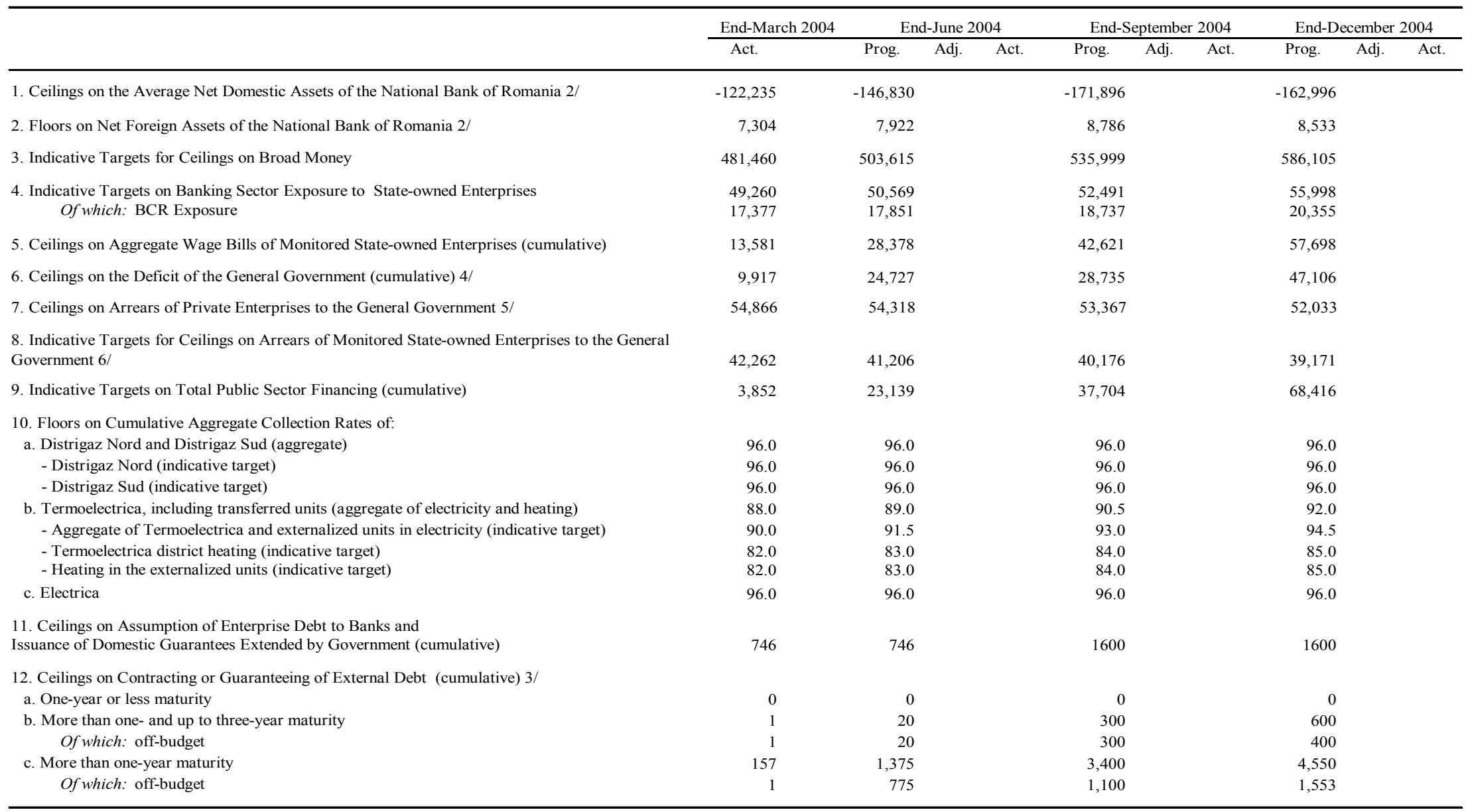

1/ The performance criteria and indicative targets envisaged under the program are defined in the Technical Memorandum of Understanding (TMU).

The figures for end-June, end-September and end-December are performance criteria, unless indicated otherwise. End-March figures are for information only.

2/ At cross exchange rates as of December 31, 2003 (as specified in the TMU, Section II), and a mandatory reserve requirement of 18 percent.

3/ Nonaccumulation of external payments arrears of the government will be a performance criterion monitored on a continuous basis.

4/ The general government is defined in the TMU.

5/ The methodology for measuring private sector arrears is defined in the TMU.

6/ The methodology for measuring SOE arrears is defined in the TMU. 
Table 2. Romania: Prior Actions, Structural Performance Criteria and Benchmarks

\section{Measures}

\section{Prior Actions:}

- Rectification of the budgets, by end-April, of the monitored SOEs in line with the 2004 wage and employment program, as specified in para. 22.

- Imposing a wage freeze on loss-making companies under AVAS (para 29).

- Official publication by March 15, 2004 of a quarterly schedule to bring gas wellhead prices in line with import parity by 2007, as specified in para. 23 .

Done

- Increase in end-user gas prices by 5 percent as of April 1, and July 1, 2004, as specified in para. 23.

Done

- Regarding the privatization of Petrom (para. 27), decide that:

(i) the entire amount of arrears in litigation to the general consolidated budget

Done would be cancelled at the time of the share transfer;

(ii) the government would take over responsibility for environmental indemnities; and

(iii) there would not be any penalties for post-privatization deviations from employment levels included in the investors' business plan.

- Government approval and publication of a strategy for restructuring the mining sector, including an action plan for 2004, and a decision on 30 mines to be closed by end-June 2004, in line with paragraph 33.

- Reduction in employment in mines by making 4,000 employees redundant by endJune, as discussed in paragraph. 33.

- Government Decision by end-March 2004 on the publication via website of audited annual income statements and balance sheets of the monitored SOEs, and their quarterly financial statements, as mentioned in para. 36 .

- Initiation of bankruptcy procedures by end-March 2004 against the top five private non-payers of tax obligations, including RAFO, as specified in para. 18.

- Reduction of employment by 15,000 employees in 33 large companies in the portfolio of AVAS, including 2,600 layoffs in Roman, as specified in para. 29.

Done

Done

Done

Done

Done

- Signing of a privatization contract for one company and initiation of liquidation procedures by a decision of general assemblies of shareholders for 5 large SOEs during January 1 - April 15, 2004, as per para. 29.

- Submission to Parliament by April 1, 2004 of legislation to eliminate the extraordinary appeal procedure of the Attorney General for all cases (para. 41).

- Government approval by May 31, 2004 of a strategy to reform the district heating

Done system, agreed with the World Bank, as per para. 25.

- Final settlement with the EBRD and the IFC on their purchase of a share package in BCR (para. 35).

Done

Done

Done 
Table 2. Romania: Prior Actions, Structural Performance Criteria and Benchmarks

\section{Measures}

- Adjustment of end-user electricity prices, effective July 1, 2004 to bring them to costrecovery levels (including return on capital for distribution companies) Adjustment of Termoelectrica's electricity and heating prices, effective July 1, 2004 to keep them at cost-recovery levels. The relevant decisions of the regulator(s) will be shared with Fund staff (para. 24).

- Adopting a new NBR law as specified in paragraph 37, by June 30.

- Approval of an Emergency Ordinance by June 10, 2004 terminating all subsidies and delivery of fuel by state-owned companies to 15 inefficient heating plants, as specified Done in para. 25.

- For each of 15 inefficient heating plants, by June 30, initiation of bankruptcy procedures by the state or a state-owned fuel supplier, or a decision by the local administration in charge on closure of the plant, as appropriate (para. 25).

- Parliamentary approval of a package of laws on the powers of the Superior Council of the Magistracy, the status of magistrates, and judicial organization by June 30 (para. 41).

- Approval of legislation strengthening the existing procedures on declaration of assets by June 30 as specified in paragraph 42 .

Done

- Invitation of binding bids for the two gas distributors DGN and DGS as specified in paragraph 28.

Done

\section{Structural Performance Criteria:}

\section{Continuous:}

- $\quad$ The minimum wage will not exceed lei 2.8 million during 2004 (para. 21).

\section{By July 20:}

- Approval of supplementary state budget in line with the revised deficit target (para. 12).

- Government Decision to increase the National Reference Price for heating by 12 percent, effective August 1, 2004 (para. 25).

- Approval of legislation to eliminate the extraordinary appeal procedure of the Attorney General for all cases (para. 41).

\section{By September 30:}

- Increase in the end-user gas prices by 5 percent, effective October 1 (para. 23).

- Implementation of 4,000 layoffs in the mining sector (para. 33).

- Repayment of the amount of health system arrears accumulated in 2002 as identified in the protocols agreed with the suppliers (para. 17). 
Table 2. Romania: Prior Actions, Structural Performance Criteria and Benchmarks

\section{By December 31:}

\section{Measures}

- Increase in end-user gas prices as per the new pricing mechanism, effective January 1, 2005 (para 23).

- Adjustment of end-user electricity prices, effective January 1, 2005 to maintain them to cost-recovery levels (including return on capital for distribution companies)

Adjustment of Termoelectrica's electricity and heating prices, effective January 1, 2005 , to keep them at cost-recovery levels. The relevant decisions of the regulator(s) will be shared with Fund staff (para. 24).

- Subordination of the customs administration and the Financial Guard to the Minister of Public Finance effective January 1, 2005 (para. 15).

\section{Structural Benchmarks:}

\section{Continuous:}

- The largest industrial nonpayers to the four utilities will stay disconnected or on minimum supply until full payments for all bills from December 2002 onwards have been received by the utilities. The bills for companies on minimum supply will be paid by the government (para. 26).

- The government will refrain from introducing tax holidays or any other new distortionary tax incentives or postponing the discontinuation of expiring ones (para. 14).

- The regulatory agency in the electricity sector will produce biannual reports on the needed adjustments in electricity and heating prices and share them with Fund staff (para. 24).

- Should any parts of Roman not pay energy bills or taxes, the utility companies or the Ministry of Finance will immediately start foreclosure proceedings (para 30).

\section{By May 31, 2004:}

- Appointment of liquidators by AVAS for 15 non-payers to the utilities (including Republica, CUG and Turnu), as per paragraph 29.

By June 30, 2004:

- AVAS will privatize or liquidate 6 large companies (para. 29).

By September 30, 2004:

- AVAS will privatize or liquidate another 6 large companies (para. 29). 


\section{TeChNiCAL Memorandum OF Understanding FOR STAND-By ARRANGEMENT}

I. Ceilings on the Average Net Domestic Assets of the National Bank of Romania

II. Targets for Floor on Net Foreign Assets of the National Bank of Romania

III. Ceilings on the Cumulative Deficit of the Consolidated General Government

IV. Ceilings on Aggregate Wage Bill of Monitored State-Owned Enterprises and Wage Bill and Employment Adjustments in Selected Companies

V. Ceiling on the Stock of Arrears of Private Enterprises to the State Budget and the Four Social Security Funds

VI. Indicative Target for Ceilings on Arrears of Monitored State-Owned Enterprises to the

Consolidated General Government

VII. Floors on Cumulative Aggregate Collection Rates of Distrigaz Sud, Distrigaz Nord, and

Termoelectrica

VIII. Ceilings on the Assumption of Enterprise Debt to Banks by the Consolidated General Government and on the Issuance of Domestic Government Guarantees on Bank Lending to Enterprises

IX. Ceilings on Contracting or Guaranteeing of External Debt

X. Indicative Targets for Ceilings on Broad Money

XI. Indicative Targets for Ceilings on Banking Sector's Total Exposure to State-Owned Enterprises

XII. Indicative Targets on the Total Public Sector Deficit Financing 


\section{Ceilings on the Average net Domestic Assets of THE NATIONAL BANK OF ROMANIA}

The average net domestic assets of the National Bank of Romania (NBR) for the indicated month are defined as the difference between average reserve money (as defined below) and average net foreign assets (as defined in Section II of this attachment), both expressed in local currency.

Average reserve money is defined as the sum of average currency in circulation outside the NBR and average deposits (required plus excess reserves) of the commercial banks at the NBR for the indicated month. Commercial bank deposits exclude required and excess reserves in foreign exchange for foreign exchange deposits. Data on reserve money will be monitored from the daily indicators data of the NBR, which shall be supplied to the IMF weekly by the NBR. The stock of average reserve money as of March 2004 was lei 111,778 billion.

The reported figures of average reserve money will be adjusted in the following circumstances:

(1) Should reserve requirements be increased/decreased from 18 percent on all required reserves held in lei, the reported reserve money figures would be increased/decreased by the product of the change in the reserve requirements and the programmed deposits for which required reserves are held in lei. The level of the programmed deposits is lei 242,609 billion for June 2004, lei 258,598 billion for September 2004 and lei 293,672 for December 2004.

(2) The reported reserve money figures will be lowered by the shortfall in actual reserves from required reserves for any individual bank, measured from the $24^{\text {th }}$ of the previous month to the $23^{\text {rd }}$ of the test-date month, as provided for in the relevant NBR regulation.

Average net foreign asset stocks will be converted into lei for the purposes of calculating average net domestic assets at the average monthly lei/U.S. dollar rates specified in consultation with Fund staff. The average stock of NFA is defined as the average of the daily NFA as defined in Section II. The limits will be monitored from daily data on the accounts of the NBR supplied weekly to the IMF by the NBR. The average NDA as of March 2004 was lei $-122,235$ billion.

The ceiling on average net domestic assets of the NBR will be adjusted under the following circumstances:

(1) Downwards (upwards), prorated for the fraction of the month that gross foreign financing exceeds (falls short of) programmed levels, specified in Section II, by the lei equivalent of the said excess (shortfall).

(2) For any change in reserve requirements as described above. Before undertaking any such changes, the NBR will consult IMF staff. 
(3) Upwards (downwards) by the lei equivalent of the decrease (increase) in the stock of foreign currency denominated Treasury bills (cumulative from end-March 2004).

(4) Downwards by the lei equivalent of the increase in foreign currency receipts from large privatizations (sale price above $\$ 10$ million, cumulative from end-March 2004), excluding proceeds from the sale of BCR, as specified in Section II.

(5) Downwards by the shortfall in actual reserves from required reserves for any individual bank.

\section{TARgets FOR FloOR ON NET Foreign ASSETS OF THE NATIONAL BANK OF ROMANIA}

Net foreign assets of the NBR consist of reserve assets minus foreign liabilities. For the purposes of the program, reserve assets shall be defined as monetary gold, holdings of SDRs, any reserve position in the IMF, and holdings of foreign exchange in convertible currencies by the NBR. Excluded from gross reserves are long-term assets, NBR redeposits at the commercial banks, any assets in nonconvertible currencies, encumbered reserve assets, reserve assets pledged as collateral for foreign loans, reserve assets pledged through forward contracts, and precious metals other than gold. Monetary gold shall be valued at an accounting price of US\$407 per ounce and SDRs at US\$1.48597 per SDR. NFA stocks are measured at the last working day of the respective month.

For the purposes of the program, foreign liabilities shall be defined as loan, deposit, swap (including any portion of the NBR gold that is collateralized), and forward liabilities of the NBR in convertible currencies including foreign currency deposits of resident commercial banks at the NBR; IMF purchases; borrowing from international capital markets; and bridge loans from the BIS, foreign banks, foreign governments, or other financial institutions, irrespective of their maturity.

All assets and liabilities denominated in convertible currencies, other than the U.S. dollar, shall be converted at their respective exchange rates against the U.S. dollar on December 31, 2003. All changes of definition or valuation of assets or liabilities as well as details of operations concerning sales, purchases, or swap operations of gold shall also be communicated to the IMF staff.

The NFA of the NBR will be adjusted: 
(i) upwards/downwards by 100 percent of the excess/shortfall of gross foreign financing ${ }^{9}$ from the programmed levels on a cumulative basis from end-March 2004 as follows:

June 2004

September 2004

December 2004
US\$756.87 million

US\$756.87 million

US\$756.87 million

(ii) by the change in the stock of foreign currency denominated Ministry of Finance Treasury Bills including those issued for bank restructuring (on a cumulative basis from endMarch 2004. The outstanding stock on March 31, 2004 was US\$450.891 million evaluated at the program exchange rates.

(iii) upwards by the amount of foreign currency receipts from large privatizations (sale price above $\$ 10$ million) (cumulative from end-March 2004), excluding proceeds from the sale of BCR, which are already included in the target.

The end-of-period NFA will be monitored on the basis of the monetary survey. Daily data will still be used, however, to calculate average NFA. All data is provided by the NBR. The end-of-period NFA figure was US\$7,304 million on March, 2004.

\section{Ceilings on the Cumulative Deficit of the CONSOLIDATED GENERAL GOVERNMENT}

The consolidated general government includes the state budget; the budgets of the local authorities; the social protection funds $;{ }^{10}$ the "Special Fund for Modernizing Roads", the "Special Fund for the Development of the Energetic System", the "Special Reinsurance Fund", the "Authority for the Sale of State Assets" (AVAS)", the "Fund for the Development of Romanian Agriculture", the "National Administration of Roads (AND)", other extra-budgetary funds managed by the Ministry of Public Finance or other Ministries and agencies outside the budgetary framework; other extra-budgetary operations of ministries financed by foreign loans; and the counterpart funds created from the proceeds of foreign loans. Any new funds created during the program period to undertake operations of a fiscal

\footnotetext{
${ }^{9}$ Foreign financing is defined as disbursements of balance of payments support loans to the government with a maturity of more than a year from multilateral and bilateral creditors and resources with a maturity of more than one year raised in the international capital markets by the government. This excludes use of IMF resources.

${ }^{10}$ These include the State Social Security Fund, the Insurance Fund for Work-Related Accidents, the Unemployment Fund, and the Health Social Insurance Fund.

${ }^{11}$ AVAS emanated from the merger of the "Privatization Agency" (APAPS) and the "Asset Recovery Agency" (AVAB) on May 1, 2004. Before this merger, APAPS was a component of the consolidated general government, while AVAB was not.
} 
nature as defined in the IMF's Manual on Government Finance Statistics will be incorporated within the definition of consolidated general government.

Under the program, the deficit of the consolidated general government will be measured based on (a) revenue and expenditure data provided by the Ministry of Public Finance as well as (b) on "below the line" financing data, i.e., the sum of domestic and external financing of the budget as well as privatization proceeds received by all entities of the consolidated general government and proceeds from the recovery of bank asset and other state assets by AVAB. All efforts will be made to reconcile the measurement of the deficit from "below" and from "above the line". However, should these efforts not succeed in eliminating the discrepancies, the respectively higher deficit number will be used for program purposes.

For program purposes, net credit of the banking system to the consolidated general government is defined as all claims of the banking system on the consolidated general government less all deposits of the consolidated general government with the banking system. Foreign-currency denominated credit to government outstanding at December 31, 2003 will be converted in U.S. dollars at the end-December 2003 exchange rate and from dollars into lei using the rates specified in consultation with Fund staff. Foreign-currency denominated credit newly issued in 2004 will be valued at the exchange rates specified in consultation with Fund staff. Government loans to banks at an interest rate less than the reference rate of the NBR to finance on lending to economic agents are excluded from government deposits; an agreed listing of the accounts to be treated as government deposits for program purposes is contained in the FAD aide memoir "Romania: Measuring the Fiscal Deficit”, Part II, Appendix 11, February 1994.

\section{Ceiling on Aggregate Wage Bill of MONITORED STATE-OWNED ENTERPRISES}

The set of 72 state-owned enterprises, whose wages are to be monitored under Emergency Ordinance 79/2001, is specified in Government Decision 393/2004.

The wage bill targets will be adjusted as follows:

(i) downwards by the amount of savings due to "externalization" (defined as the spinning off of a unit or its transfer to another entity, or temporary/permanent transfers of employees when the sum of these transfers exceeds 100 employees per month). In each month, savings from externalization will be calculated on a company by company basis as the product of the number of externalized employees so far and the company's average gross wage.

(ii) if a company is privatized, downwards by the budgeted wage bill of the privatized company, starting with the month in which the privatization contract is signed.

The wage bills will be measured on a cumulative basis across the different sectors, on a monthly basis. The Ministry of Labor and Social Protection will undertake the responsibility 
of collecting data from the various line ministries (regie autonomes and national companies) and AVAS (commercial companies), and will report the wage bills and employment figures for each of the monitored enterprises (including aggregate figures for each ministry and for the overall total) to the IMF on a monthly basis. Employment reduction resulting from all forms of outsourcing will be reported in the "externalization" column of the respective tables, with a footnote, if necessary.

\section{Ceiling on the Stock of Arrears of Private Enterprises to the State BUDGET AND THE FOUR SOCIAL SECURITY FUNDS}

The ceiling applies to the outstanding stock of arrears of the set of 452 private companies (fully private or with state-ownership of less than 50 percent) monitored by the National Agency for Fiscal Administration (NAFA). These 452 companies are a subset of the 549 companies (private as well as state-owned) with the largest arrears to the state budget and the four social security funds as of December 31, 2003. Data on the stock of arrears of these 549 companies are published on a quarterly basis on the external website of the Ministry of Public Finance (with a breakdown into arrears to the state budget and each of the four social security funds; separately for the stock of arrears including and excluding interest and penalties). The complete data set is provided to Fund staff on a monthly basis with a reporting lag of at most 35 calendar days following the end of the respective month. The performance criterion refers to the stock of arrears excluding interest and penalties. Changes in the stock of arrears owing to the cancellation of arrears will not be reflected in the data used for measuring the stock of arrears under the program. Fund staff has to be notified on a company-by-company basis about all cancellations of arrears within at most 5 business days following the approval of the cancellation. For changes to the set of monitored companies, the targets will be adjusted downwards/upwards by the amount of arrears of the companies removed/added to the set. In particular, in the case of the privatization of a fully state-owned company or a majority state-owned company on the above-referenced list of the 549 companies, the respective company will be added to the list of private companies (for the base date as well as for future test dates) to which the performance criterion applies. These companies will be added to the list in the moment of the final and binding signature of the privatization contract. In the case of the initiation of bankruptcy procedures against a company on the above-referenced list of 452 companies, the respective company will be removed from the list (for the base date as well as for future test dates) to which the performance criterion applies. These companies will be removed from the list in the moment in which the file requesting bankruptcy is submitted to court. The stock of arrears at end-March 2004 was lei 54,866 billion. 


\section{Indicative TARget for Ceilings on ARrears of Monitored State-owned ENTERPRISES TO THE CONSOLIDATED GENERAL GOVERNMENT}

The ceiling applies to the outstanding stock of arrears of the set of 72 monitored state-owned enterprises, whose arrears are to be monitored under Emergency Ordinance 79/2001 and Government Decision 393/2004. Under the ordinance, arrears are defined as accounts payable past the due date stipulated explicitly in the contracts, or if no such explicit date exist, 30 days after services/products are provided. The reporting on total arrears will have the following subcategories: to the state budget, to the social security budget; to the local budget; to special funds; and to other creditors. Arrears to the consolidated general government are defined as the sum of the first four categories. Amounts reflecting tax arrears exclusive of penalties will be reported separately. For arrears which have been rescheduled/canceled, the rescheduled/canceled amounts (including penalties) will not be counted as arrears reduction, and has to be reported. The report will include a breakdown of arrears to the ten largest creditors for each company. The report will also include data on overdue claims of each of the monitored companies, as reported under Emergency Ordinance 79/2001 and Government Decision 393/2004. For changes to the set of monitored companies owing to privatization or the initiation of bankruptcy procedures, the targets will be adjusted downwards/upwards by the amount of arrears of the companies removed/added to the set. Data for monitoring purposes shall be supplied monthly to Fund staff by the Ministry of Public Finance by at most 35 calendar days after the end of the respective month. The stock of arrears at end-March 2004 was lei 42,262 billion.

\section{Floors on Cumulative Aggregate Collection Rates of Distrigaz Sud, DISTRIGAZ NORD, TERMOELECTRICA AND ELECTRICA}

Floors will be set on the cumulative collection rates of the following companies:

- the combined rate (performance criterion) of Distrigaz Nord and Distrigaz Sud (indicative targets on the individual company collection rates);

- on the combined collection rate for heating and electricity of Termoelectrica, including the production units externalized to local authorities (performance criterion). Indicative targets will be set on the collection rates for (i) electricity for both Termoelectrica and the production units externalized to local authorities; (ii) Termoelectrica's district heating; (iii) heating in the externalized units;

- on Electrica's collection rate (performance criterion).

The floors on collection rates are defined as follows: 
(i) Termoelectrica and local authority units (Heating sector), Distrigaz Nord and Sud: Heating and gas bills are lagged by one month. Definition of 12-month moving collection rate $\mathrm{c}(\mathrm{m})$ for the month $\mathrm{m}=1,2 . .12$.:

$\mathrm{c}(\mathrm{m})=\quad$ sum(heating collections $(\mathrm{m})$ :heating collections $(\mathrm{m}-12)$ divided by sum(heating bills(m-1):heating bills(m-13)).

(ii) Termoelectrica and local authority units (Electricity sector); Electrica; Definition of 12-month moving collection rate $\mathrm{c}(\mathrm{m})$ for the month $\mathrm{m}=1,2 . .12$ :

$\mathrm{c}(\mathrm{m})=\operatorname{sum}($ electricity collections $(\mathrm{m})$ :electricity collections $(\mathrm{m}-12)$ divided by sum(electricity bills(m):electricity bills(m-12)).

Using these definitions, the collection rate of Termoelectrica including the externalized units at end-December 2003 was 87.9, of Electrica 98.1, and of the two gas companies 98.8. Data for these companies will be collected by the Ministry of Economy and Commerce and reported to the IMF on a monthly basis. Revenue resulting from obtaining shares through debt-equity swaps will be excluded from collections, unless the shares are sold for cash. The Ministry of Economy and Commerce will include in this report data on billings and collections registered by Distrigaz Nord, Distrigaz Sud, Electrica and Termoelectrica, as well as information on possible dis- and reconnections for the following industrial (a) and heating (b) companies.

a) SC Siderurgica, COS Targoviste, Minvest SM-Rosia Poieni, Moldomin, Minvest-SM, Balan, Snif, SC Industria Sarmei, Gavazzi Steel, Minvest-SM Baia de Aries, SC Turnu, CUG Cluj, SC Apaterm Galati, SC Tractorul UTB, SC Chimcomplex, Minvest- SM Brad, Apa Nova (RGAB), Minvest -SM Coranda Certej, Minvest -SM Poiana Rusca Teliuc, Siderca, SC Electrocarbon, Tepro, Nitramonia, Viromet, Amonil, Oltchim, Sere Codlea, US Govora, Republica, Zahar Bod, Stirom Bucuresti, Danubiana, Gerom Buzau, Colorom Codlea, Roman Brasov, Metrom Brasov, Carfil Brasov, Stiaz Azuga, Faur Bucuresti, UPSOM SA Ocna Mureş, Bicapa SA Târnăveni, SC Ind.Sârmei C.Turzii, SC Stipo SA Dorohoi, Ampellum SA Zlatna, SC Cugir SA, SC Melana Săvinești, Letea Bacau, Rafo SA Oneşti, SC Fortus SA Iaşi, Ambro SA Suceava, Stratusmob SA Blaj, SC Sticla Turda, Iris SA Cluj, Metalurgica Aiud.

b) Radet Bucuresti, Radet Constanta, Apaterm Galati, RA Termoficare Craiova, SC Apaterm, SA Deva, Termica SA Targoviste, Termoficare Petrosani, Dalkia Ploiesti, SC Termoficare Petrosani, SC Universal Lupeni, Aptercol Braila, SC Citadin Aninoasa, RA Termoficare Cluj, SC Aqua Calor P. Neamt, RA Energomur Tg Mures, SC Energ. Temica Sibiu, Termoloc Populatie Bacau, RA Goscom Roman, Proditerm Bistrita, Rail Hunedoara, Comunala RA Satu Mare, Termica SA Botosani, Enet Focsani, Cet Braila, Cet Govora, RA Termo Craiova, Ram Buzau, RA Termo Brasov, Aquaterm Tg. Jiu, Aquaterm 98 Pitesti.

Also, to monitor actual payments in the electricity sector, the Ministry of Economy and Commerce will include in these reports the following tables on monthly payments.

a) a table containing amounts billed to Electrica by power generators, paid by Electrica to power generators, and the payment rate (i.e. the second column divided by the first column). 
The table will contain a separate line for amounts billed and collected related to the developments tax and hence amounts billed an collected by Electrica itself should exclude the development tax.

b) Four collection rate tables from Termoelectrica containing amounts billed to and received from electricity distribution companies. Table one contains the total amounts billed and received, table two contains amounts billed and received from Electrica, table three contains amounts billed and received from Hidroelectrica, and table four contains amounts billed and received from other TE customers. Hence the amounts in tables 2-4 should add up to the amounts in table 1. Each table should be split up according to the amounts billed and received by the various Termolectrica plants, i.e. Termoelectrica-core, Rovinari, Turnceni, Craiova, Deva.

For the period January 2004-April 2004, these tables will be compiled retrospecitively. From April 2004 onwards, these tables will be included in the monthly reports on collection rates.

The exchange rate (ROL per USD) used to calculate the annual producer gas price increase of at least \$25/tcm (LoI paragraph 23) per January 1 of each of the years 2005-2007, will not be lower than the average exchange rate in the month of November preceding the date of the increase.

\section{CeILING ON THE ASSUMPTION OF ENTERPRise DebT to BANKS BY THE CONSOLIDATED GENERAL GOVERNMENT AND ON THE ISSUANCE OF DOMESTIC GOVERNMENT GUARANTEES ON BANK LENDING TO ENTERPRISES}

The ceiling applies to the cumulative stock from end-March 2004 of newly guaranteed or assumed domestic debt by the consolidated general government. For program purposes, the assumption of enterprise debt to banks by the consolidated general government and the issuing of a guarantee to assume enterprise debt to banks are treated as being equivalent. This limit includes any loan on which the government pays or guarantees interest, even if the principal is not guaranteed. The consolidated general government is defined in Section III of this attachment. The criterion also applies to the use of AVAS resources for recapitalizing enterprises or as collateral for bank loans. Foreign currency denominated loans will be converted at accounting exchange rates specified in consultation with Fund staff.

This ceiling excludes:

- the contracting or guaranteeing of external debt, for which separate limits are set out in Section IX of this attachment;

- debt transferred in the process of bank restructuring, privatization or liquidation of stateowned enterprises; and 
- the assumption of debt as a result of an activation of a guarantee or collateral.

Data for monitoring purposes shall be supplied monthly to the IMF by the Ministry of Finance. The stock of guarantees and debt assumed as described in this section was lei 746 billion as of end-March 2004.

\section{Ceilings on Contracting or Guaranteeing of External Debt}

The ceilings apply to the cumulative flow since the beginning of each year of newly contracted or guaranteed external debt by the consolidated general government. The consolidated general government is defined in Section III of this attachment. This performance criterion applies not only to debt as defined in point No. 9 of the IMF Guidelines on Performance Criteria with Respect to Foreign debt adopted on August 24, 2000 (Executive Board Decision No. 12274-(00/85)) but also to commitments contracted or guaranteed for which value has not been received. The ceilings also apply to any assumption of loans for debt outstanding which were not previously contracted or guaranteed by the consolidated general government. Excluded from the ceilings are liabilities to the IMF and bridge loans from the BIS, foreign banks, foreign governments, or any other financial institution. Debt falling within the ceilings shall be valued in U.S. dollars at the exchange rate prevailing at the time the contract or guarantee becomes effective. Loans considered concessional are also excluded from the ceilings. Off-budget debt includes all debt to nonbudget entities from private sector creditors guaranteed by the Ministry of Finance. Loans for fuel imports for Distrigaz, Romgaz, Termoelectrica, and the 23 heat-producing units which were transferred from Termoelectrica to local authorities, and any further units externalized during the program, are included in the overall ceilings, and the appropriate off-budget guaranteed debt ceilings.

Concessional loans are defined as those with a grant element of at least 35 percent of the value of the loan, using currency-specific discount rates based on the commercial interest reference rates reported by the OECD (CIRRS) in effect at the time of contracting or guaranteeing the loan.

The ceiling on contracting and guaranteeing external debt with maturity over one year includes an Eurobond in the amount of $€ 600$ million (see paragraph 19 of the MEFP). In case an Eurobond is not issued or is issued for a smaller amount, the ceiling will be adjusted downwards by 100 percent of the shortfall on a cumulative basis from end-March 2004 as follows:

June 2004

September 2004

December 2004
US\$ 0 million

US\$780 million

US\$780 million

For the purposes of this adjustor only, an exchange rate of US\$1.3/€1 will be used. 
The ceilings shall be monitored from data supplied monthly to the IMF by the Ministry of Finance. The accumulated since January 1 flow of contracted or guaranteed debt at endMarch 2004 was US\$157 million for maturities over one year (US\$1 million of which was off-budget), US\$1 million for the subceiling of debt with maturity of one to three years (all of which was off-budget), zero for debt with less than one year maturity.

Nonaccumulation of external payments arrears of the government will be a performance criterion monitored on a continuous basis. For program purposes, arrears with respect to called-up sovereign loan guarantees are defined as external payments overdue more than 30 days.

\section{INdiCATIVE TARgets For CEILINGS ON BROAD MONEY}

Broad money is defined as the liabilities of the banking system with the non-bank public. Broad money includes foreign currency deposits of residents, but excludes government deposits and deposits of foreign monetary institutions and other non-residents. For the purposes of the program, deposits which are denominated in foreign currency will be converted into lei at the accounting exchange rates specified in consultation with Fund staff.

Data on broad money will be monitored from the monthly monetary survey data, which shall be supplied to the IMF monthly by the NBR. The stock of broad money was lei 481,460 billion as of March 31, 2004.

\section{IndiCATIVE TARGETS FOR CEILINGS ON BANKING SECTOR'S TOTAL EXPOSURE TO STATE-OWNED ENTERPRISES}

Total exposure covers all loans, advances, holdings of debt and off-balance sheet exposure of resident banks to state-owned enterprises. Data on loans will also be reported separately from total exposure. State-owned enterprises are all regie autonomes, national and commercial companies with majority ownership by the general government, as defined in Section III of this attachment. For the purposes of monitoring, foreign currency denominated debt will be converted in lei at end-month leu/U.S. dollar exchange rates specified in consultation with Fund staff. Foreign currency denominated credit in convertible currencies, other than the U.S. dollar, shall be converted at their respective exchange rates against the U.S. dollar as specified in Section II. Data on banking sector lending to state-owned enterprises will be monitored from monthly data provided by the NBR.

The amount of total exposure, as reported by the NBR, will include (on a cumulative basis from end-March 2004):

(i) exposure to companies where the majority ownership shifted to the private sector. For this purpose, AVAS and the relevant ministries will provide a monthly update of their portfolio to the NBR; 
(ii) any amount of debt or off-balance sheet write-offs; and

(iii) any assumption of debt or off-balance sheet items by the general government or other public bodies.

Additionally, the NBR will report monthly on total exposure of the banking system to stateowned enterprises with outstanding exposure over lei 100 billion, on a company-by-company basis. The stock of banking sector exposure to state-owned enterprises at program exchange rates as of March 31, 2004 was lei 49,260 billion of which lei 17,377 billion was to BCR.

\section{Indicative Targets on the Total Public Sector Deficit Financing}

The Public Sector Deficit Financing is monitored on a monthly basis and compiled by the Ministry of Finance, with data also supplied to the Ministry by the NBR and the National Securities and Exchange Commission (CNVM). It consists of the financing of the consolidated general government as defined in Section III and the state-owned enterprises.

The consolidated general government financing consists of net external financing, nonbank financing, and bank financing. Net External Financing comprises sovereign bond and BOP support loans, on-budget project financing, leasing operations of ministries and local governments, and T-bills, issued domestically, held by non-residents (computed separately in lei and foreign exchange). Non-Bank Financing comprises privatization receipts (total privatization receipts of all components of the general government independent of whether they are transferred to the treasury), asset recovery (AVAS receipts from asset recovery transferred to the consolidated general government), municipal bonds (bonds issued by the municipalities either domestically or internationally, computed as the difference between issuance and redemptions during the month), and T-bills and bonds held by the non-bank public (computed separately in lei and foreign exchange). Bank Financing is defined as the sum of T-bills and bonds in lei held by banks, T-bills and bonds in foreign currencies held by banks, bank loans in lei and foreign currencies, decrease in government deposits in lei (a positive number indicates a decline in deposits), and decrease in government deposits in foreign currencies (a positive number indicates a decline in deposits).

The state owned enterprises financing consists of net external financing, bank financing, and the accumulation of arrears. Net External Financing comprises of state-guaranteed bills and bonds (excluding called guarantees and including state-guaranteed fuel imports), bills and bonds without state guarantee, state-guaranteed loans (excluding called guarantees), and loans without state guarantee. Bank Financing is defined as the sum of the increase in credit to SOEs (computed separately in lei and foreign exchange), and decrease in SOEs deposits (computed separately in lei and foreign exchange; a positive number indicates a decline in deposits). The accumulation of arrears is defined as increase of arrears to the general government by the group of 72 large monitored SOEs, excluding interest and penalties as specified in the law. 
The monthly flows of financing are approximated by the following methodologies:

(i) for stocks in lei-change of stocks between the end of the respective months;

(ii) foreign exchange stocks expressed in lei are first converted in U.S. dollar stocks using the end-month leu/U.S. dollar exchange rate. Then the change in U.S. dollar stocks is converted in lei by using the monthly average leu/U.S. dollar exchange rate;

(iii) foreign exchange flows expressed in U.S. dollars are converted in lei by using the monthly average leu/U.S. dollar exchange rate; and

(iv) conversion of stocks and flows in foreign currency other than the U.S. dollar in U.S. dollars is done according to the convention of the reporting institution (usually, the market exchange rate either at the time of the transaction or at the end of the month).

The principal providers of data are:

(i) the Ministry of Finance on:

- sovereign bonds and BOP support loans;

- on-budget project financing;

- privatization receipts;

- asset recovery;

- state-guaranteed bills and bonds;

- state-guaranteed loans (excluding called guarantees); and

- the accumulation of SOE arrears to the general government by the group of 72 large monitored SOEs.

(ii) the NBR on:

- leasing operations of ministries and local governments;

- T-bills, issued domestically, held by non-residents;

- T-bills and bonds held by the non-bank public;

- T-bills and bonds in lei and foreign currencies held by banks;

- T-bills and bonds in foreign currencies held by banks;

- bank loans in lei and foreign currencies, including to the "National Road Administration" (AND);

- decrease in government deposits in lei and foreign currencies, including deposits of the "National Road Administration"( AND);

- externally issued bills and bonds by SOEs without state guarantee,

- external loans to SOEs without state guarantee;

- domestic bank loans to SOEs; and

- decrease in SOEs deposits with domestic banks.

(iii) the National Securities and Exchange Commission on local government bonds. 


\section{Statement by the IMF Staff Representative \\ July 7, 2004}

1. This statement summarizes information that has become available since the issuance of the staff report for the 2004 Article IV consultation and Request for Stand-By Arrangement. The staff appraisal remains unchanged.

2. Recently released macroeconomic data are broadly in line with the agreed program.

- $\quad$ Industrial production rose 5.2 percent year-on-year in April, compared to 4.2 percent in Q1. This, and the already stronger than expected GDP growth in Q1, suggests the possibility of an upward revision in GDP growth projection for 2004.

- $\quad$ The 12-month headline inflation rate fell to 12.3 percent in May, about $1 / 2$ percentage point below the program projection.

- $\quad$ The current account deficit for the four months through April reached 1.2 percent of annual GDP, in line with the annual program target.

- In May, economy wide net wage growth was relatively high (9 percent in real terms compared to a year earlier), similar to growth in January-April. However, real wage growth in the monitored state-owned enterprises is hovering around zero, in line with the program.

- $\quad$ The general government budget deficit was contained to 0.5 percent of annual GDP in January-May, reflecting buoyant revenue performance and expenditure restraint early in the year.

- $\quad$ To prevent nominal appreciation, the NBR bought $€ 390$ million in June, bringing total purchases to $€ 1.1$ billion in Q2. In response to the lower inflation and the persistent excess supply on the foreign currency market, the NBR cut its policy rate by 50 basis points on June 7 , to 22.8 percent.

3. All prior actions have been fully met, except for one, the main objectives of which was, however, observed. Regarding the permanent closure of 15 inefficient district heating plants, the mayors of the corresponding districts confirmed that the heating services of all the plants had been terminated, about half which had already ceased operations in 2003. As the government incurred legal problems in the rapid liquidation of these plants, it approved a decree that, in addition to terminating all subsidies to these plants, requested from the local councils to adopt measures for their permanent closure or reorganization. As the government is committed not to reinstate the subsidies, without which the plants cannot function, the objective of the agreed prior action has been achieved. Staff therefore recommends that the Board approve the program. 
4. On May 25, the authorities eliminated the authority of the prosecutor general to reopen civil cases after their adjudication by courts ("extraordinary appeal procedure"). (The World Bank also saw this procedure as undermining the integrity of the judicial process and the autonomy of the judiciary). The corresponding structural PC under the program has therefore been met.

5. FIN completed the safeguards assessment of the National Bank of Romania (NBR) on June 17, 2004. The safeguard framework was found to be considerably improved and generally adequate. Regarding the remaining weaknesses, the main recommendations were that (i) the NBR establish a statutory deadline for completing external audits within three to four months after the end of the financial year; and (ii) strengthen the procedures for reviewing the compilation of data reported to the Fund under the program. The authorities have agreed with the recommendations and staff will monitor their implementation in the context of the program supported by the Stand-By Arrangement. 
Press Release No. 04/137

FOR IMMEDIATE RELEASE

July 7, 2004
International Monetary Fund

Washington, D.C. 20431 USA

\section{IMF Approves US\$367 Million Stand-By Arrangement with Romania}

The Executive Board of the International Monetary Fund (IMF) today approved a 24-month Stand-By Arrangement for an amount equivalent to SDR 250 million (about US\$367 million) for Romania. The Romanian authorities do not intend to make any drawings since they are treating the arrangement as precautionary.

Romania's previous Stand-By Arrangement with the IMF for a total amount equivalent to SDR 300 million (about US $\$ 440$ million) expired on October 15, 2003 (see Press Release No. 03/171). On April 12, 2004, the Executive Board reviewed Romania's experience with Fundsupported programs since the early 1990s, under the new guidelines on assessments of countries with a longer-term program engagement (see Public Information Notice No. 04/44).

Following the Executive Board discussion, Anne Krueger, First Deputy Managing Director and Acting Chair, said:

"The Romanian authorities are to be commended for their sound macroeconomic policies and progress in structural reforms, which have contributed to continued disinflation and robust GDP growth in 2003. The authorities' program - supported by a new Fund arrangement, which the authorities intend to treat as precautionary-aims at strengthening the external current account balance, further reducing inflation, sustaining rapid GDP growth, and preparing the economy for EU accession. The program emphasizes continued prudent macroeconomic policies and progress with wide-ranging structural reforms.

"Key stabilization policies are a reduction in the general government budget deficit, a strengthening of the finances of state-owned enterprises through energy price adjustments and wage restraint, and measures to contain credit growth. Wage restraint by state-owned companies and a prudent statutory minimum wage policy will help to keep economy-wide wage growth in line with productivity growth. The program includes efficiency-enhancing adjustments in fiscal revenue and expenditure. Further cuts in social security taxes are envisaged, together with measures to broaden the tax base and improve tax administration. However, the successful VAT and profit tax reforms would be put at risk by introducing exemptions, which would create new distortions and undermine tax administration. Prioritization of expenditure will help finance investment in infrastructure. 
"Monetary and exchange rate policies will continue to aim at striking a balance between reducing inflation and maintaining Romania's external competitiveness. The authorities are intensively preparing for the introduction of inflation targeting, and an important step in this direction was the approval of the new central bank law strengthening the central bank's independence. Supervisory procedures and regulation have been strengthened to stem the risks arising from rapid growth in credit to households, and the authorities stand ready to take further measures if necessary.

"The authorities are confronting the long-standing issues of tax arrears and nonpayment of utility bills by large loss-making state-owned enterprises. The largest loss-makers will be downsized, and employees will be assisted in retraining and relocation. Notable progress has been made in privatization, with future efforts concentrating on the energy sector. Particularly encouraging is the authorities' strong commitment to privatize Petrom, the largest company in the country.

"With the passage of a number of new and amended laws, the authorities have started an overhaul of the judicial system, which will contribute to improving the business climate, strengthening the judicial system's independence, and improve the capacity to address the problem of corruption," Ms. Krueger said. 


\section{Recent Economic Developments}

Under the most recent Stand-By Arrangement, macroeconomic imbalances were reduced through tight fiscal policy, strong measures to improve the financial performance of state-owned enterprises, and accelerated privatization. Between 2000-03, Romania's GDP growth averaged about 4.5 percent and is estimated to reach 5 percent in 2004. The National Bank of Romania (NBR) gradually reduced the depreciation rate and achieved substantial disinflation, lowering the annual inflation rate to 12.3 percent in May 2004 from 40 percent in early 2001.

Macroeconomic stabilization, which preserved the competitiveness achieved with the 1999 depreciation, and improved prospects for EU accession created a positive supply response, strengthening industrial production and exports. In 2003, however, domestic demand strengthened and the current account deficit widened to almost 5.9 percent of GDP. Fiscal policy provided continued support for macroeconomic stabilization. The successful value-added tax (VAT) and profit tax reforms, improvements in tax administration, and savings on interest payments helped reduce the budget deficit relative to GDP to 2.3 percent in 2003 from 2.6 percent in 2002 .

Improved confidence of banks and households, and a lower perception of country risk premium led to very rapid credit growth of about 55 percent in real terms in 2003. Consumer and mortgage credit tripled in real terms, albeit from a low base, while corporate credit also remained strong. However, the tightening of eligibility criteria for consumer and mortgage credit in early 2004 was successful in mitigating credit expansion.

Following a decade of slow privatization, the privatization of large state-owned companies accelerated in 2003 and 2004, following the implementation of a large-scale employment reduction program to attract investor interest. Moreover, after several delays, a number of important privatization projects in the energy sector are now close to completion, including the privatization of Petrom, the largest company in the country.

\section{Program Summary}

The Romanian government aims at strengthening macroeconomic stabilization and structural reforms in the run-up to EU accession in 2007. The program is designed to address the recent surge in the current account deficit, rapid credit growth, and the need to bring inflation to single digits. Fiscal consolidation and measures to contain credit growth will be crucial for containing domestic demand.

The fiscal stance of the broad public sector (general government and state-owned enterprises) will be tightened relative to GDP by $1 \frac{1}{4}$ percentage points compared with the 2003 outcome. Credit growth is expected to slow to about 35 percent in real terms on average, which will help moderate domestic demand. As a result, the external current account deficit in 2004 is projected 
to decline by $3 / 4$ percentage points to $5 \frac{1 / 4}{4}$ percent of GDP relative to 2003 , while end-2004 inflation would be lowered to 9 percent from 14.1 percent at the end of 2003.

The authorities will reduce the 2004 general government deficit ceiling to 2.1 percent of GDP, compared to 3 percent of GDP in the approved budget. Owing to very strong revenue performance, this reduction can be achieved exclusively by saving surplus revenue, which the authorities estimate at 0.9 percent of GDP. Energy price adjustments and wage policy will be the main instruments for improving the state-owned enterprises' financial position.

Monetary policy will focus on lowering inflation to single digits in 2004. The current exchangerate-based framework remains appropriate, and the NBR will use both interest rate policy and selective market interventions to steer the exchange rate consistent with the inflation target and a modest real appreciation. However, the authorities will need to remain vigilant in keeping the current account deficit well within safe margins. While fiscal policy would have to lead this process, the NBR would closely watch credit growth and implement additional measures if necessary.

On the structural side, the priorities are accelerated privatization - including the privatization of Petrom, measures to arrest the accumulation of arrears, and improved governance.

The authorities are intensifying efforts to improve collections of the main utilities. The program provides for further decisive steps to increase domestic gas producers' price toward import parity by 2007 and adjust electricity prices. The authorities will initiate decisive restructuring in the large loss-making mining and railway sectors, responsible for the build of arrears to the budget and energy suppliers.

The authorities are making significant efforts to improve governance and the agreed program includes conditionality for judicial reform, including the strengthening of judicial independence. Further measures aim at improving the business climate by strengthening the office of the special anticorruption prosecutor, increasing transparency on issues of privatization and financial disclosure, and enforcing tax collections. 
Romania: Main Economic Indicators, 2000-2004Q1

$2000 \quad 2001 \quad 2002 \quad 2003 \quad 2004$ Q1 1/

GDP

$\begin{array}{llll}2.1 & 5.7 & 5.0 & 4.9\end{array}$

6.1

Final domestic demand

$\begin{array}{llll}2.1 & 6.9 & 3.5 & 7.3\end{array}$

7.9

Total consumption

$1.5 \quad 6.3$

2.4

6.9

8.1

Gross fixed capital formation

$\begin{array}{llll}5.5 & 10.1 & 8.2 & 9.2\end{array}$

7.3

Net exports (contribution)

$\begin{array}{lllll}-2.3 & -3.1 & 0.9 & -2.8 & -1.1\end{array}$

Exports of goods and services

$\begin{array}{llll}23.4 & 12.1 & 17.6 & 11.1\end{array}$

10.2

Imports of goods and services

$\begin{array}{llll}27.1 & 18.4 & 12.0 & 16.3\end{array}$

12.4

Current account

$\begin{array}{llll}-3.9 & -5.5 & -3.4 & -5.9\end{array}$

$-0.5$

(percent of annual GDP)

12-month inflation (eop)

$\begin{array}{llll}40.7 & 30.3 & 17.8 & 14.1\end{array}$

11.8

Official reserves (eop, US\$ million)

$\begin{array}{llll}3466 & 5090 & 6975 & 7994\end{array}$

8303

Sources: National Institute for Statistics; Ministry for Economic

Development

and Forecasting; and IMF Staff projections.

1/ Preliminary data and staff estimates. 


\section{Statement by Yuriy G. Yakusha, Alternate Executive Director for Romania and Lucian Croitoru, Senior Advisor to Executive Director \\ July 7, 2004}

\section{The Broad Picture}

The Romanian authorities appreciate the staff report, which accurately assesses the country's performance in recent years and provides a realistic view of the policy challenges ahead. They broadly agree with staff recommendations and consent to the Fund's publication of the report.

In the context of the previous successfully concluded SBA, Romania has made progress both in strengthening the macroeconomic environment and in promoting structural reforms, thus reducing macroeconomic imbalances. In 2003 the authorities overperformed for the third year in a row by reducing the fiscal deficit to 2.3 percent of GDP relative to the target of 2.7 percent of GDP. The National Bank of Romania (NBR) implemented prudent policies and disinflation targets were constantly met in the last three years. From 41 percent at end-2000, inflation went down to $12 \frac{1}{3}$ percent in May 2004, and available figures indicate that the 2004 target of 9 percent is likely to be met. Macroeconomic stabilization has preserved competitiveness, while official reserves have maintained comfortable import cover levels. Several measures to improve the financial performance of state owned enterprises (SOEs) were implemented, including significant upward adjustments in energy prices and higher collection rates in the gas and electricity sectors. Privatization has accelerated, with 35 large companies with over 112000 employees being privatized in 200103, of which half in the course of the last year, and further progress has been made in Q1 2004. The financial sector is healthy, with liquid and well-capitalized banks. Progress with stabilization, continued strong competitiveness, and improved prospects for EU accession have ensured a robust response of the economy, with GDP growth averaging 5.2 percent a year in 2001-03, and 6.1 percent in the first half of 2004.

Looking forward, the authorities view consolidating macroeconomic stabilization and accessing the $\mathrm{EU}$ in $\mathbf{2 0 0 7}$ as interlinked goals, which require intense structural reform. To secure further progress in macroeconomic stabilization, the authorities will employ further fiscal consolidation and a prudent monetary and exchange rate policy, including measures to contain the rapid credit growth. In view of adopting inflation targeting in 2005, strong efforts will be devoted to complete the technical preparation and further formalize the policy framework, including shifting the responsibility for managing developments in the external current account to fiscal and income policies. In accordance with guidelines in the Ex Post Assessment, the authorities are determined to move further with imposing hard budget constraints, accelerating the privatization process in the energy sector, and improving governance and the business environment, thus achieving mediumterm external viability.

In addressing these challenges, the authorities are convinced that a new precautionary 24-months SBA is crucial to anchor ownership of reforms and to reduce balance of payments vulnerabilities. The strong conditionality of the program, based on 
front-loaded measures and supported by prior actions (which have all been met), is in line with recommendations of the Ex Post Assessment. The successful implementation of structural reforms under this program should facilitate exiting from Fund program engagement. As also recommended in the Ex Post Assessment, the authorities, but also our chair, started a public relations policy to help preparing public perception for the future graduation to a surveillance-based relationship.

\section{Fiscal policy}

Fiscal policy will continue to play a decisive role in disinflation and in keeping the current account deficit within safe margins, while creating scope for further private sector investment. Consistent with this mission, the authorities decided to tighten the general government deficit to 2.1 percent of GDP, 0.9 percent of GDP below the approved budget. Given the very strong revenue performance, this deficit adjustment can be achieved entirely by saving the revenue surplus. The authorities will keep expenditure to the programmed level if revenue comes out stronger than consistent with the budget target, but are also ready to tighten fiscal policy further if the current account or disinflation targets are at risk. Expenditure for all motorway projects will be accommodated within the new budget. In addition, measures envisaged to improve the saving-investment balances of the SOEs (energy price adjustments and wage control in 72 large SOEs) would allow for an overall adjustment in the broad public sector deficit of more than 1 percent of GDP. To ensure that the fiscal objective for the broad public sector is met, this year the authorities will establish monthly monitoring of the public sector borrowing requirement.

On tax policy, the authorities decided to continue their policy to reduce payroll tax rates, improve tax administration and step up the fight against tax arrears accumulation. In January 2004 the authorities reduced the employers' contributions to the pension fund ( 2.5 percentage points) and to the unemployment fund ( 0.5 percentage point). They have limited the eligibility for the reduced VAT rate to pharmaceutical products, hotel accommodation, newspaper distribution, and a small group of previously VAT-exempted products. No other modification in tax legislation is planned for 2004 and any amendments that may be envisaged for 2005 will be done in consultation with Fund staff. The modernization of the newly established revenue administration will now focus on operations, systems and processes, and human resources. In their fight against tax arrears, the authorities have initiated bankruptcy procedures against a large private refinery and other companies that incurred tax arrears.

To ensure the long-term sustainability of the public pension fund, the authorities are committed to the World Bank's proposal to accelerate the increase in the retirement age and to equalize it for men and women starting with July 1, 2005. These reforms would be necessary to compensate for the envisaged further cuts in social security rates, which are relatively high, but also for the foreseeable increases in the already high dependency ratio and for the low replacement ratio.

\section{Monetary policy}

In 2004 the NBR will continue to apply the same monetary policy strategy before moving to inflation targeting (IT) in 2005. Since early 2001, the strategy of guiding the exchange rate along a path consistent with the inflation objective, in the context of restricted 
capital inflows and positive real interest rates, has proved efficient in gradually lowering inflation. Both the authorities and staff believe that such strategy could deliver further disinflation in 2004. The NBR will use both interest rate policy and selective market intervention to keep the exchange rate consistent with the inflation target through a modest annual real appreciation against the implicit euro-dollar basket. Reacting to favorable developments with respect to inflation and to excess supply in the foreign exchange market, the NBR has reduced the policy interest rate by 50 bps in June 9, and is contemplating further interest rate reductions aimed at confirming disinflation progress, while maintaining the prudent stance of monetary and exchange rate policy. With a view towards enhancing longerterm policy effectiveness, the NBR has started preparation for adopting an IT framework for monetary policy. The legal underpinnings of such a shift are incorporated in the recently adopted NBR Law, which fully transposes EU central banking acquis, guaranteeing price stability as a primary objective, as well as consolidating the independence of the central bank. Efforts are currently being undertaken to establish the institutional, operational and analytical prerequisites for a successful implementation of IT in line with suggestions from the MFD TA mission. Moving to full inflation targeting will require progress in strengthening information gathering, analysis and forecasting techniques, formalizing monetary policy decision-making, and further increasing transparency through improved communication.

To address risks associated with rapid credit growth, the NBR will continue to improve its instruments for managing the financial system. Although the financial system appears healthy, on-site supervision will be enhanced to make sure that credit increases associated with the process of financial deepening and cyclical movement of the economy will not adversely affect the resilience of credit institutions to macroeconomic shocks. The NBR will also perform additional systematic assessment of risk exposure through stresstesting of portfolios and more conservative regulatory practices will be adopted in relevant areas if necessary.

\section{Wage policy}

Wage policy is aimed at managing demand pressures. Therefore, the government approved a prudent annual increase of 12 percent in the statutory minimum wage on January 1,2004 . To ensure a prudent wage policy in the SOE sector, the government also limited the average net real wage growth to about 1 percent and decided to reduce employment by 5 percent. To strengthen the credibility of the wage bill target, the ministries will block payments equivalent to 4 percent of the quarterly wage bill in 72 monitored SOEs until the last month of the quarter, and will release these amounts only when it is clear that the respective target will be reached. In response to recent pressures from labor unions, who are pushing for higher minimum wages in a nation-wide collective contract, the government will instruct managers in SOEs and use its influence to prevent significant deviations of the agreed minimum wage from the statutory minimum wage.

\section{Structural reforms and the business climate}

Under the new SBA the authorities will adopt a more forceful approach to privatization (including selling the largest company in the country, Petrom), strengthen financial and payment discipline in SOEs, and improve governance. Progress in these 
areas will improve the business climate and will allow the Romanian economy to become a full functioning market economy, able to withstand competition within the EU.

Privatization in the energy sector is a high priority, privatization of the SOEs in the privatization authority's portfolio is to be completed by end-2004, and decisive restructuring will be initiated in the large loss-makers in the mining and railway sectors. Four electricity distribution companies are scheduled to be privatized in 2004, the authorities being close to sign contracts for two of them. For two gas distribution companies bids are expected by mid-July. Furthermore, the authorities will start discussion with the World Bank on the privatization of Romgaz, the Romanian gas producer, and two big power generators. In the railway sector the authorities intend to continue restructuring efforts by closing by end-June 2004 about $3000 \mathrm{~km}$ of loss-making secondary lines if the respective segments are not taken over by investors. In the mining sector, they agreed to close 30 mines, laying off 8,000 miners in 2004. In addition, the authorities have adopted an ambitious strategy for restructuring the mining sector, approving the phasing out of state support for the mineral and coal sector by 2007 and 2010 respectively, in line with the EU commitments. Efforts to complete privatization in the banking sector will also continue. The authorities' remaining shares in BCR will be sold as soon as possible, in agreement with EBRD and IFC. The timetable for the privatization of CEC, the State Savings Bank, was decided in April this year, with a view to completion in 2005, and a tender to select the consultant for privatization was announced in May.

The authorities will continue to reduce losses from quasi-fiscal activities in the energy sector and eliminate the nonpayment of electricity and gas. Price adjustments have allowed losses from quasi-fiscal activities in the energy sector to decrease from 4.7 percent of GDP in 2000 to 2.8 percent in 2003. For the gas sector, the authorities have decided to move to a new price system, under which distributors and end-users will have to absorb variable import costs and a gradual increase in producer prices to import parity. To this end, the final user gas price will be further increased by 5 percent every quarter in 2004, and the authorities have also announced a schedule for further increases in the producer gas prices so as to reach import parity in 2007. Electricity prices will continue to be adjusted not only to cover rising cost, but also to provide an appropriate margin for return on equity in the distribution sector, to facilitate privatization. Efforts to fight nonpayment in the electricity and gas distribution sectors are already reflected in significant increases in bill collection rates. Further efforts to increase collection rates will focus on the closure of unviable industrial consumers with large arrears, seizure of assets from nonpayers through the judiciary system, and intensified efforts to improve collection from households. In addition, the authorities are working on a reform strategy for the district heating system. This strategy will be based on: (i) switching to heating contracts with individuals, (ii) termination of subsidies to at least 15 inefficient heating plants, (already implemented) and (iii) increasing both the heating price (12 percent as of July 1, 2004, already met) and the National Reference Price for heating (12 percent as of August 1, 2004). The authorities will also enhance the existing targeted support for households with a view to abolishing the National Reference Price. To mitigate the social impact of structural reforms, the administrative capacity of the social safety net will be improved and the coverage of the minimum income guarantee scheme will be broadened. 
Efforts to improve governance, strengthen public administration, eliminate corruption and improve the business climate are underway. In cooperation with the World Bank and in response to EU recommendations, the authorities have approved laws on judicial organization, on the status of magistrates, and on the Superior Council of the Magistrates. The new laws strengthened the role of the Superior Council of the Magistrates as guarantor of the independence of the judiciary. Stepping up the fight against corruption is a prerequisites for further improvements in the business climate and should remains top priority of the reform agenda. The extraordinary appeal procedure by the Attorney General has already been eliminated. Furthermore, the legislation on the declaration of assets by government and parliamentary officials and near-relatives has been strengthened to be more effective in containing corruption. The National Prosecutor's Anti-Corruption Office (ANC) will be provided with additional resources this year. In early 2005 , in cooperation with the World Bank and within the framework of the EU acquis, the authorities will overhaul the new labor code and amend it in order to promote greater labor market flexibility.

In closing, we would like to convey to the management and staff of the Fund the appreciation of the Romanian authorities for their continuing support, frankness in discussion and constructive policy advice. 


\section{INTERNATIONAL MONETARY FUND}

Public Information Notice

EXTERNAL

RELATIONS

DEPARTMENT

Public Information Notice (PIN) No. 04/75

FOR IMMEDIATE RELEASE

July 27,2004

International Monetary Fund

$70019^{\text {th }}$ Street, NW

Washington, D. C. 20431 USA

\section{IMF Concludes 2004 Article IV Consultation with Romania}

On July 7, 2004, the Executive Board of the International Monetary Fund (IMF) concluded the 2004 Article IV Consultation with Romania. ${ }^{1}$

\section{Background}

After uneven performance in the 1990s, macroeconomic policies improved in 2001-03. Macroeconomic imbalances were reduced through fiscal policy, measures to improve the financial performance of state-owned enterprises (SOEs), and accelerated privatization. The National Bank of Romania (NBR) slowed the depreciation of the leu and achieved substantial disinflation, lowering the annual inflation rate from 40 percent in early 2001 to 12.3 percent in May 2004. Macroeconomic stabilization, which preserved the competitiveness achieved with the 1999 depreciation, and prospects for EU accession created a positive supply response and facilitated rapid growth over the last three years.

However, in 2003 domestic demand picked up and the current account deficit widened, reflecting a sharp increase in credit to the private sector and a large minimum wage increase in January 2003. As a result, final domestic demand grew faster than output and the current account deficit widened to 5.9 percent of GDP.

Fiscal policy provided continued support for macroeconomic stabilization. Far-reaching valueadded tax (VAT) and profit tax reforms and improvements in tax administration strengthened

\footnotetext{
${ }^{1}$ Under Article IV of the IMF's Articles of Agreement, the IMF holds bilateral discussions with members, usually every year. A staff team visits the country, collects economic and financial information, and discusses with officials the country's economic developments and policies. On return to headquarters, the staff prepares a report, which forms the basis for discussion by the Executive Board. At the conclusion of the discussion, the Managing Director, as Chairman of the Board, summarizes the views of Executive Directors, and this summary is transmitted to the country's authorities.
} 
revenue collections despite sizable cuts in social security contribution rates. With interest payments declining, the budget deficit was reduced relative to GDP from 2.6 percent in 2002 to 2.3 percent in 2003 . The authorities were also successful in reducing losses from quasi-fiscal activities. After a delayed policy response to higher international prices in early 2003, gas prices have been increased substantially since mid-2003, and electricity prices were brought to the cost recovery level in September 2003. Collection rates in the gas and electricity sectors increased significantly, but progress has been insufficient in district heating.

After a decade of slow privatization, a large-scale employment reduction program facilitated an acceleration of the privatization program. Overall, 35 large companies with over 112,000 employees were privatized in 2001-03, half of which were privatized in the last year. Although energy sector privatization has been slow, a number of important privatization projects are now close to completion, the most important of which is the privatization of oil and gas producer Petrom, the largest company in the country.

\section{Executive Board Assessment}

Executive Directors commended the Romanian authorities for the prudent conduct of macroeconomic policies and progress with structural reforms. These achievements have contributed to a decline in inflation and to Romania's strong economic growth over the past three years.

Directors stressed that sustaining strong growth over the medium term will require further efforts to complete macroeconomic stabilization and accelerate structural reform. In particular, continued disinflation and containing the current account deficit within a safe range, in the context of the current exchange rate-based stabilization framework, will require further efforts to reduce the budget deficit over the medium term, eliminate losses and quasi-fiscal activities in state-owned enterprises, and implement a strict wage policy. In the structural area, Directors emphasized the importance of completing the privatization agenda and stepping up efforts to improve the business climate, especially governance. It will be particularly important to keep up the momentum on these policies in the run-up to the general elections in November 2004 and in their immediate aftermath.

Directors commended the authorities' plan to lower the general government deficit in the context of the amended 2004 budget, and to use any additional revenue for further deficit reduction. They stressed the importance of maintaining a sufficiently tight fiscal policy over the medium term. Directors encouraged improvements in the structure of revenue and expenditure to support further budget consolidation efforts. They welcomed the reduction in Romania's high social security contribution rates, and supported further cuts in these provided they are accompanied by a broadening of the tax base and improvements in tax administration. Directors cautioned against eroding the value added and profit tax bases through the granting of exemptions. They strongly supported efforts to reduce subsidies, and noted that expenditure will need to be carefully prioritized to make room for planned increases in infrastructure investment. It was suggested that the articulation of a medium-term expenditure framework could usefully support such efforts. 
Directors generally considered that the current monetary policy framework, which features a gradually declining targeted depreciation rate as a nominal anchor, has been a key factor underlying the success in reducing inflation. Directors agreed that once inflation has been brought down to single-digit levels and wage discipline in state-owned companies strengthened, inflation targeting will become a viable framework for the medium term. Steps to strengthen the central bank's independence in line with Maastricht requirements, are welcome, and Directors encouraged the authorities to step up efforts to fulfill the institutional, operational, and analytical prerequisites for the introduction of inflation targeting in 2005. Directors noted that the banking system remains healthy, and that recent measures have been effective in containing the growth of household credit. Nevertheless, they recommended that the authorities remain vigilant and prepared to take additional measures should the brisk growth of credit resume.

Directors stressed the need for hard budget constraints on state-owned enterprises.

They welcomed the measures directed at reducing tax arrears and the nonpayment of utility bills, particularly in the mining and railway sectors. Directors supported the closing of unviable operations, with appropriate provision for relocating and retraining employees, and the adjustment of prices to fully cover costs. They commended the authorities' decision to raise gas prices to import parity, and also encouraged them to implement the recently-approved strategy for the district heating sector.

Directors welcomed the authorities' commitment to prudent wage policies, considering that this will be critical for maintaining macroeconomic stability and reducing state-owned enterprise losses. While commending the moderate increase of the statutory minimum wage and the tight state-owned enterprise wage program in 2004, they urged the authorities to remain firm in the implementation of these policies. They also underscored the need to keep wage settlements in collective labor contracts in line with productivity growth, thereby protecting employment and competitiveness.

Directors stressed that preserving labor market flexibility will be key to keeping the economy on a fast growth path and completing the far-reaching restructuring process. Accordingly, they urged the authorities to review the provisions in the newly-approved Labor Code that have adversely affected flexibility and increased the burden on small and medium-sized enterprises.

Directors welcomed the authorities' plan to offer most of the state-owned companies outside the energy sector for sale by end-2004. They also stressed the importance of accelerating privatization in the energy sector. Directors encouraged the authorities to continue reducing employment in state-owned enterprises, as they considered this necessary for reducing losses and accelerating privatization.

Directors commended the authorities for the recent progress in improving the business climate, including judiciary reform and the implementation of measures to fight against corruption. To attract higher private investment, it will be crucial to sustain these institutional reforms, further strengthen the fight against corruption-in particular through further efforts to increase the independence and effectiveness of the judiciary-and improve transparency in privatization and public procurement. 
It is expected that the next Article IV consultation with Romania will be held on the 24-month cycle, subject to the provisions in the decision on the consultation cycles approved by the Board on July 15, 2002.

Public Information Notices (PINs) form part of the IMF's efforts to promote transparency of the IMF's views and analysis of economic developments and policies. With the consent of the country (or countries) concerned, PINs are issued after Executive Board discussions of Article IV consultations with member countries, of its surveillance of developments at the regional level, of post-program monitoring, and of ex post assessments of member countries with longer-term program engagements. PINs are also issued after Executive Board discussions of general policy matters, unless otherwise decided by the Executive Board in a particular case. The Staff Report for the 2004 Article IV Consultation with Romania is also available. 
Selected Economic Indicators

\begin{tabular}{|c|c|c|c|c|c|c|}
\hline & 1999 & 2000 & 2001 & 2002 & 2003 & $\begin{array}{l}2004 \\
\text { Proj. }\end{array}$ \\
\hline \multicolumn{7}{|l|}{ Real economy (change in percent) ${ }^{1}$} \\
\hline Real GDP & -1.2 & 2.1 & 5.7 & 5.0 & 4.9 & 5.0 \\
\hline Final domestic demand & -2.9 & 2.1 & 6.9 & 3.5 & 7.3 & 6.0 \\
\hline CPI (end of period) & 54.8 & 40.7 & 30.3 & 17.8 & 14.1 & 9.0 \\
\hline CPI (period average) & 45.8 & 45.7 & 34.5 & 22.5 & 15.3 & 11.5 \\
\hline Unemployment rate (end of period; percent) & 11.8 & 10.5 & 8.8 & 8.4 & 7.2 & 6.5 \\
\hline Gross national saving (percent of GDP) & 11.9 & 15.6 & 17.0 & 20.1 & 18.7 & 19.6 \\
\hline Gross domestic investment (percent of GDP) & 16.1 & 19.5 & 22.6 & 23.5 & 24.6 & 24.8 \\
\hline \multicolumn{7}{|l|}{ Public finance (general government, percent of GDP) } \\
\hline Overall balance & -3.6 & -4.0 & -3.2 & -2.6 & -2.3 & -2.1 \\
\hline Primary balance & 2.4 & 0.9 & 0.6 & 0.4 & -0.2 & 0.0 \\
\hline Total public debt (in percent of GDP) ${ }^{2}$ & 33.2 & 31.3 & 28.6 & 28.3 & 26.6 & 26.5 \\
\hline \multicolumn{7}{|l|}{ Money and credit (end of year, percent change) } \\
\hline Real domestic credit ${ }^{3}$ & -7.6 & 9.9 & 27.9 & 33.1 & 55.4 & 21.4 \\
\hline Broad money & 44.9 & 38.0 & 46.2 & 38.1 & 23.3 & 27.2 \\
\hline \multicolumn{7}{|l|}{ Interest rates (percent) } \\
\hline NBR interest rates (end of period) ${ }^{4}$ & 88.7 & 60.1 & 39.9 & 21.5 & 23.4 & 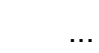 \\
\hline Treasury bill rate (end of period) & 104.8 & 59.4 & 38.4 & 17.4 & 18.4 & $\ldots$ \\
\hline \multicolumn{7}{|l|}{ Balance of payments (percent of GDP) } \\
\hline Trade balance & -3.5 & -4.6 & -7.4 & -5.7 & -7.9 & -7.0 \\
\hline Current account balance & -4.0 & -3.7 & -5.5 & -3.4 & -5.8 & -5.2 \\
\hline External debt & 25.6 & 28.7 & 30.7 & 34.3 & 34.6 & 33.2 \\
\hline Official reserves (end-year, US\$ million) & 2,472 & 3,466 & 5,090 & 6,975 & 7,994 & 9,664 \\
\hline Reserve cover (months of prospective imports) & 2.1 & 2.5 & 3.2 & 3.5 & 3.3 & 4.2 \\
\hline \multicolumn{7}{|l|}{ Exchange rate } \\
\hline Lei per U.S. dollar (end of period) & 18,250 & 25,926 & 31,597 & 33,500 & 33,013 &. \\
\hline NEER appreciation (+) (annual average in percent) & -39.8 & -22.8 & -22.3 & -14.4 & -11.1 & 玫竹 \\
\hline REER appreciation $(+)(\mathrm{CPI}$-based, annual average in percent & -15.0 & 9.3 & 1.5 & 2.6 & 0.4 & $\ldots$ \\
\hline $\begin{array}{l}\text { REER appreciation }(+)(\mathrm{CPI} \text { excl. admin prices, annual } \\
\text { average in percent }\end{array}$ & $\cdots$ & 6.0 & 1.8 & 1.0 & 0.0 & $\ldots$ \\
\hline REER appreciation (+) (ULC-based, annual average in percent) & -21.8 & -0.3 & -0.9 & -6.7 & -5.6 & $\ldots$ \\
\hline
\end{tabular}

Sources: Romanian authorities and IMF staff estimates.

${ }^{1}$ In 2002, national accounts data starting 1998 have been revised due to methodological change (adoption of ESA95 guidelines).

${ }^{2}$ Including domestic public debt and external public debt (public and publicly guaranteed).

${ }^{3}$ Credit to the nongovernment sector. Weighted average of real lei credit growth and U.S. dollar-measured foreign currency credit growth.

${ }^{4}$ NBR's deposit auction interest rate, compounded. 